Spring 2018

\title{
Metamorphic Evolution of the Sierra de Maz: Implications for the Timing of Terrane Accretion on the Western Margin of Gondwana
}

Andrew Tholt

Western Washington University, tholta@wwu.edu

Follow this and additional works at: https://cedar.wwu.edu/wwuet

Part of the Geology Commons

\section{Recommended Citation}

Tholt, Andrew, "Metamorphic Evolution of the Sierra de Maz: Implications for the Timing of Terrane Accretion on the Western Margin of Gondwana" (2018). WWU Graduate School Collection. 713. https://cedar.wwu.edu/wwuet/713

This Masters Thesis is brought to you for free and open access by the WWU Graduate and Undergraduate Scholarship at Western CEDAR. It has been accepted for inclusion in WWU Graduate School Collection by an authorized administrator of Western CEDAR. For more information, please contact westerncedar@wwu.edu. 
METAMORPHIC EVOLUTION OF THE SIERRA DE MAZ: IMPLICATIONS FOR THE TIMING OF TERRANE ACCRETION ON THE WESTERN MARGIN OF GONDWANA

\author{
By \\ Andrew Tholt \\ Accepted in Partial Completion \\ of the Requirements for the Degree \\ Master of Degree Name
}

ADVISORY COMMITTEE

Dr. Sean Mulcahy

Dr. Elizabeth Schermer

Dr. Bill McClelland

GRADUATE SCHOOL

Dr. Gautam Pillay, Dean 


\section{Master's Thesis}

In presenting this thesis in partial fulfillment of the requirements for a master's degree at Western Washington University, I grant to Western Washington University the nonexclusive royalty-free right to archive, reproduce, distribute, and display the thesis in any and all forms, including electronic format, via any digital library mechanisms maintained by WWU.

I represent and warrant this is my original work, and does not infringe or violate any rights of others. I warrant that I have obtained written permissions from the owner of any third party copyrighted material included in these files.

I acknowledge that I retain ownership rights to the copyright of this work, including but not limited to the right to use all or part of this work in future works, such as articles or books.

Library users are granted permission for individual, research and non-commercial reproduction of this work for educational purposes only. Any further digital posting of this document requires specific permission from the author.

Any copying or publication of this thesis for commercial purposes, or for financial gain, is not allowed without my written permission.

Andrew Tholt

June 11, 2018 


\author{
A Thesis \\ Presented to \\ The Faculty of \\ Western Washington University
}

In Partial Fulfillment

Of the Requirements for the Degree

Master of Science

by

Andrew Tholt

June 2018 


\begin{abstract}
The Mesoproterozoic MARA terrane of South America has been interpreted to collide and subduct beneath the Gondwana margin of South America in the Cambrian. To test the proposed tectonic model, I combine metamorphic petrology and geochronology along with quantitative thermobarometry to constrain metamorphic events and peak conditions within the Sierra de Maz of the MARA terrane and the adjacent Sierra de Ramaditas. Foliations within the Sierra de Maz are steeply east dipping, with a major sinistral reverse shear zone separating the two major units (Zaino and Maz Complexes) of the northern range. Garnet Lu-Hf records a single metamorphic event in the Zaino Complex at $\sim 425 \mathrm{Ma}$. Combined garnet Lu-Hf and monazite U-Pb reveal a polymetamorphic history in the Maz Complex with two distinct metamorphic events at $\sim 1.2 \mathrm{Ga}$ and $\sim 425 \mathrm{Ma}$. Both Complexes were deformed by sinstral transpression between 435 and $415 \mathrm{Ma}$. Preserved across these Complexes is a Silurian-Devonian amphibolite to granulite inverted metamorphic field gradient that is compatible with observed and modeled gradients from other transpressive orogens. The Ramaditas complex records lower-pressure granulite facies metamorphism at $\sim 460 \mathrm{Ma}$, was deformed at $\sim 426 \mathrm{Ma}$, and is correlated with the Famatina arc rather than its previously proposed affiliation to units in the Sierra de Maz. Units of the Sierra de Maz do not share metamorphic histories with nearby ranges within the proposed extent of the MARA terrane. Age dissimilarities require that portions of the MARA terrane were tectonically juxtaposed likely as a result of transpressive translation along the Gondwana margin.
\end{abstract}




\section{Acknowledgements}

Special thanks to my advisor, Dr. Sean Mulcahy, for his dedication to my education and his willingness to share knowledge. I'll never be able to thank Sean enough for allowing me to be a part of this project and to work with everyone involved. Thanks to my committee member, Dr. Elizabeth Schermer, for insightful discussion both in and outside of the classroom and for inspiring me to be a better scientist at every point of my career. Thanks to my committee member, Dr. Bill McClelland, for his holistic mentoring in the field and during data collection in the laboratory. Thanks to Dr. Sarah Roeske for her insights in the field and her commitment to mentoring students. Thanks to my stellar field assistant Wes Johns, and to Dr. Matt Coble of Stanford University.

This work was supported in part by funding from the Western Washington University graduate school and Department of Geology. Funding was also supported by the National Science Foundation Grant No. 1550110. Any opinions, findings, and conclusions or recommendations expressed in this material are those of the authors and do not necessarily reflect the views of the National Science Foundation. 


\section{Table of Contents}

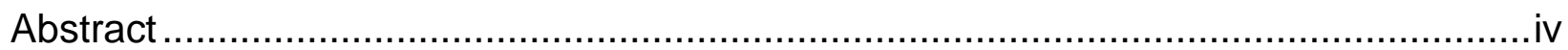

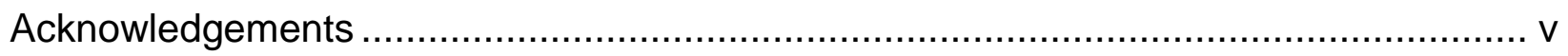

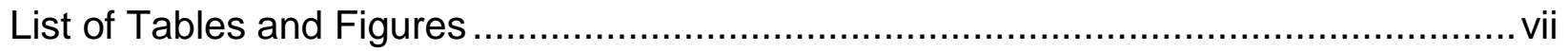

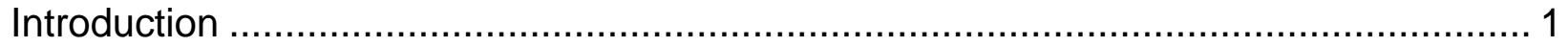

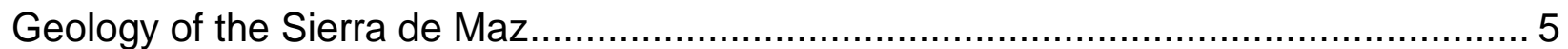

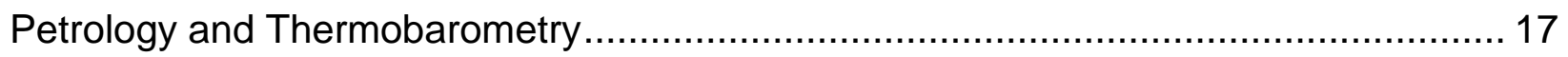

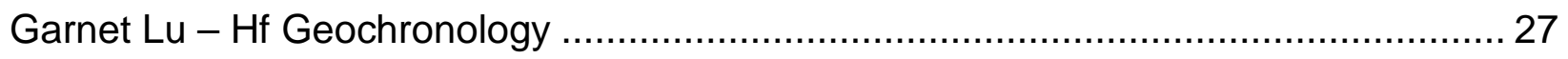

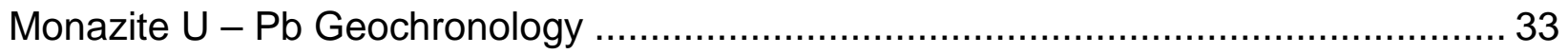

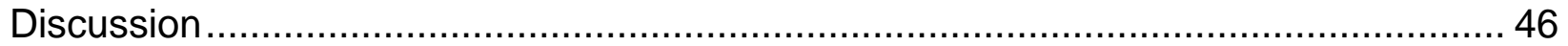

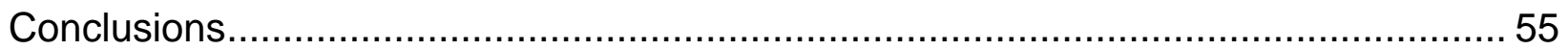

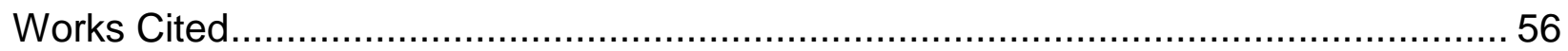




\section{List of Figures}

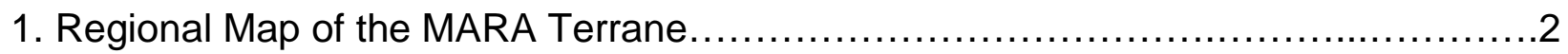

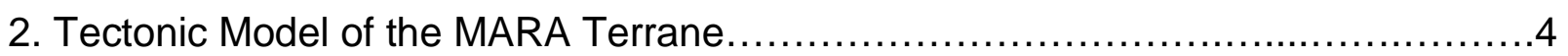

3. Geologic Map of the Western Sierras Pampeanas...................................

4. Geologic Map of Northern Sierra de Maz..........................................11

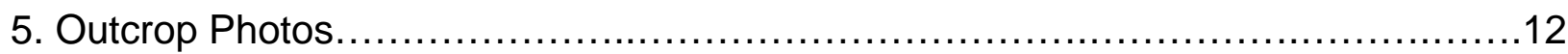

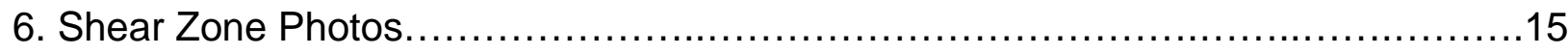

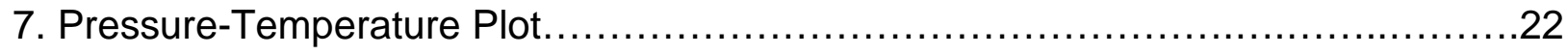

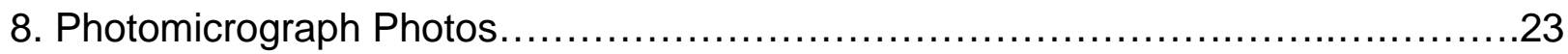

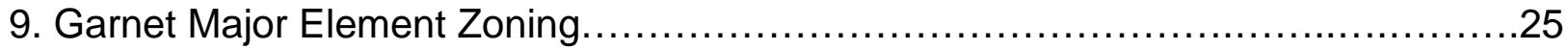

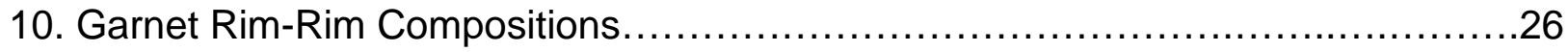

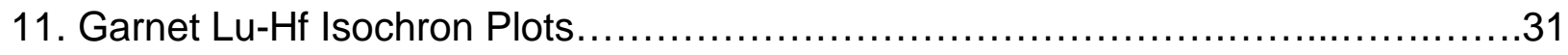

12. Garnet Rim-Rim Lu Distribution ....................................................

13. Sample AT-076 Monazite Back Scatter Electron Images..............................35

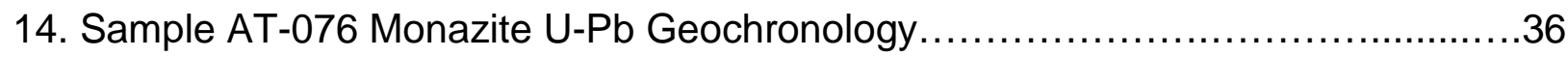

15. Sample AT-068 Monazite Back Scatter Electron Images............................38

16. Sample AT-068 Monazite U-Pb Geochronology ...................................39

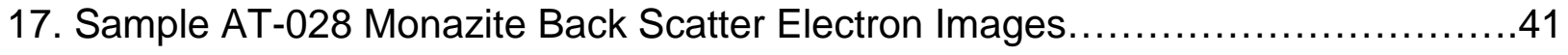

18. Sample AT-028 Monazite U-Pb Geochronology .................................42

19. Sample AT-047 Monazite Back Scatter Electron Images...........................44

20. Sample AT-047 Monazite U-Pb Geochronology .................................45

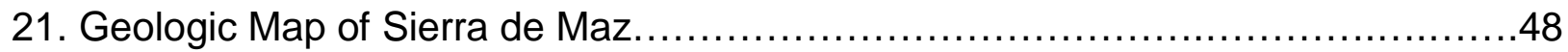

22. Pressure-Temperature Plot vs Structural Distance ..............................52

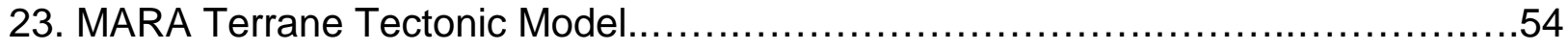




\section{List of Tables}

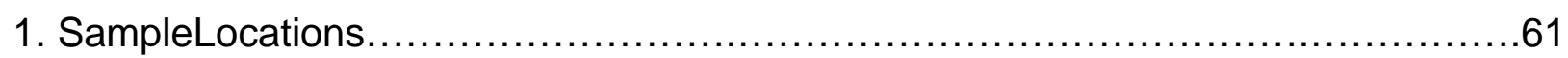

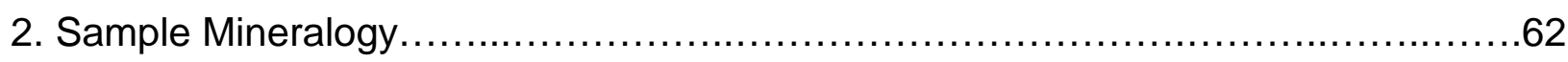

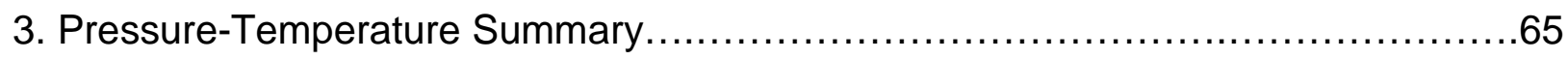

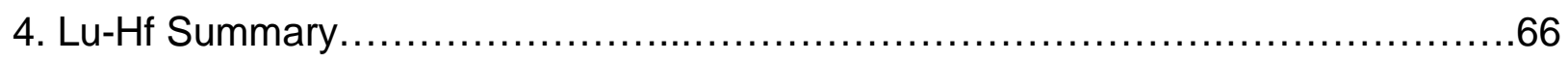

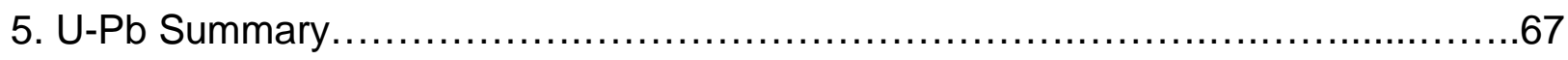

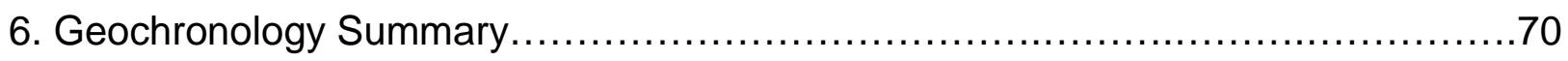

\section{List of Digital Appendices}

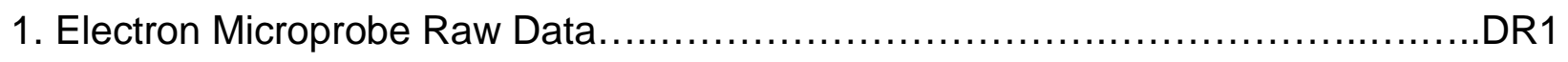

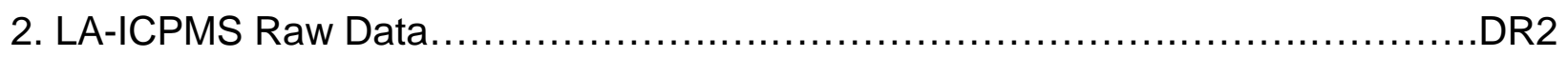




\section{Introduction}

Collisional orogens are among the most complex tectonic settings on Earth and exhumed metamorphic rocks record processes that take place during convergence, collision, and exhumation. Classically held models of orogeny invoke a simple cycle of crustal thickening followed by exhumation (e.g., Thompson and England, 1984) and successfully reproduce pressure-temperature paths preserved in many metamorphic terranes. Exhumed orogens, however, often record multiple episodes of thickening and exhumation, magmatic addition, and/or orogen parallel translation which give rise to complicated metamorphic histories (e.g. Brown and Talbot, 1989; Mulcahy et al., 2014). Testing proposed tectonic models in these orogens requires detailed metamorphic and structural studies in order to reconstruct the most accurate pressure, temperature, and deformation history.

The western margin of South America preserves a poorly understood and complex orogenic belt that is critical to Paleozoic plate reconstructions and the relative positions of Laurentia and Gondwana. Basement exposures within the Maz, Arequipa, and Rio Apa (MARA) ranges span almost the entire length of South America, are located immediately west of the Famatina continental arc, with the prevailing tectonic model based largely on observations in the Western Sierras Pampeanas of northwest Argentina (Figure 1). The MARA terrane is interpreted as Laurentian-derived crystalline basement that preserves two metamorphic episodes at 1200 Ma and between 460-430 Ma (Lucassen and Becchio, 2003; Casquet et al., 2006). The current tectonic model assumes that MARA rifted from Laurentia around $570 \mathrm{Ma}$ and then collided and was partially subducted beneath the Rio de la Plata craton around 530 Ma (Rapela et al., 
2016; Figure 2). Direct evidence for $\sim 570$ Ma rifting comes from a carbonatite intrusion found within the Sierra de Maz of the MARA terrane, but high temperature rift-related metamorphic ages have yet to be documented. Evidence for a $\sim 530$ Ma collision is indirectly inferred from cessation of arc volcanism within the Rio de la Plata craton but direct evidence for this event is absent within MARA (Rapela et al., 2016; Figure 2).

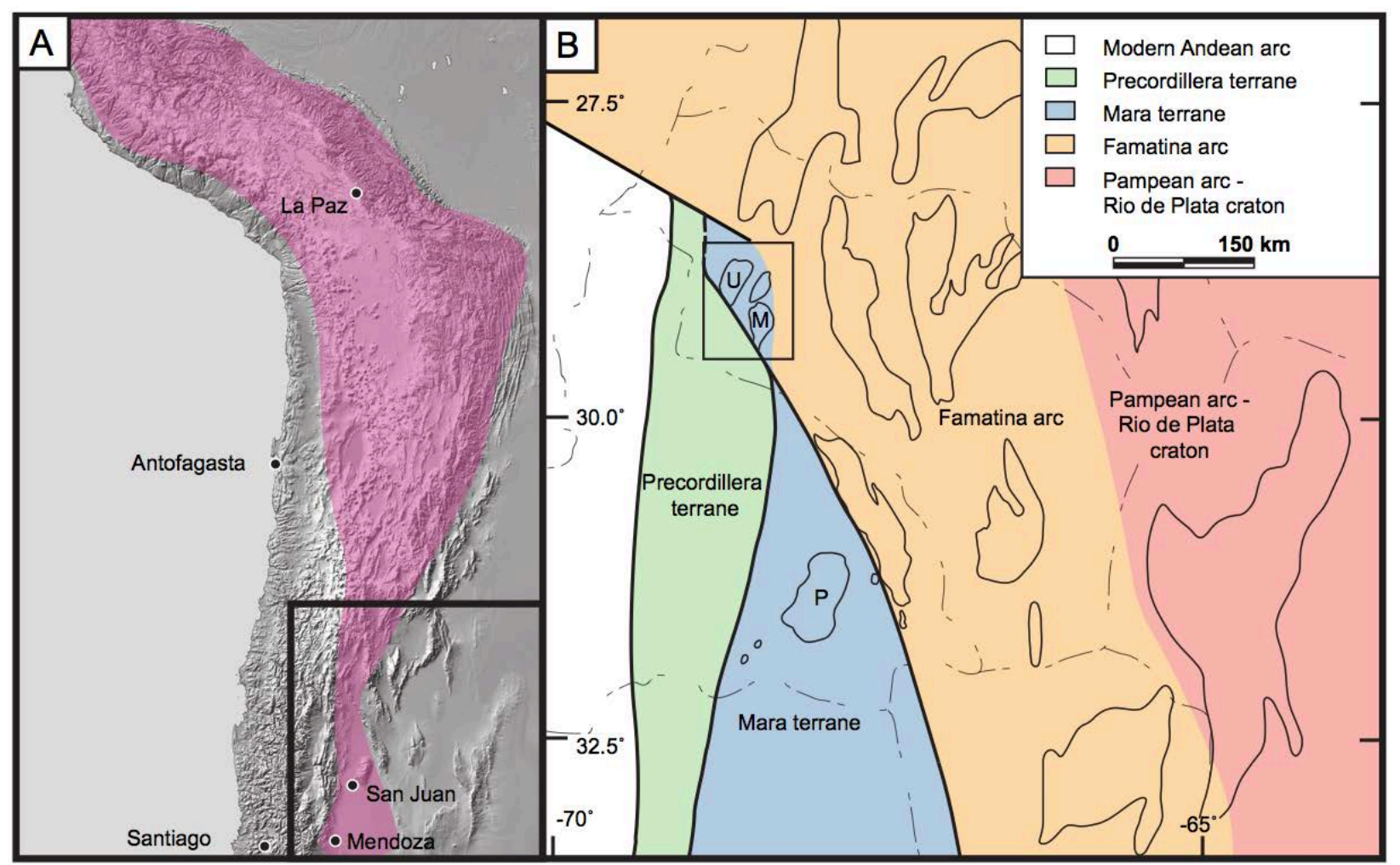

Figure 1: A) Proposed extent of the MARA terrane (magenta) and geographic location of map area in panel B. B) Geologic map of the Western Sierra Pampeanas, modified from Mulcahy et al. 2011. Abbreviations: M, Sierra de Maz; P, Sierra de Pie de Palo; and U, Sierra de Umango. Thick line weights indicate proposed terrane boundaries, thin weights outline important mountain ranges, dash-dot lines are major roadways. Boxed region is the extent of Figure 3. 
Existing metamorphic ages from the MARA terrane are difficult to reconcile with the proposed tectonic model as this region records seemingly different metamorphic and deformational histories. Basement exposures in the Sierra de Pie de Palo (Figure 1) record lower-crustal Cambrian to Middle Ordovician shortening along low angle shear zones (Mulcahy, 2007; Mulcahy, 2011) between 515-430 Ma. In contrast, the Sierra de Maz exposes mid-crustal rocks with steep fabrics interpreted to record oblique to strike-slip deformation of unknown age. Inferred metamorphic U-Pb ages within the Sierra de Maz of 460-430 Ma reported by Casquet et al. (2003) are not explained by the Rapela (2016) model. The ages imply that potentially, 1) the collision and juxtaposition of the MARA terrane with the Rio de Plata craton is younger than assumed, 2) metamorphic ages within the MARA terrane represent cooling ages or are misinterpreted, or 3) metapelitic rocks recording 530-520 Ma metamorphism and deformation have yet to be sampled.

In order to test the Rapela et al. (2016) tectonic model for the MARA terrane, I combine quantitative thermobarometry with $\mathrm{Lu}-\mathrm{Hf}$ and $\mathrm{U}-\mathrm{Pb}$ geochronology to constrain the conditions and timing of metamorphism and deformation within the Sierra de Maz of the MARA terrane. The data suggest that rocks within the Sierra de Ramaditas are barometrically and chronologically distinct from the rest of the MARA terrane and likely represent a contact aureole more closely associated to the adjacent Famatina arc. The Sierra de Maz records Silurian to Devonian sinistral transpression and an amphibolite to granulite inverted metamorphic field gradient. 
(a) ca. $630 \mathrm{Ma}$. Opening of the transient Puncoviscana/Clymene ocean/sea

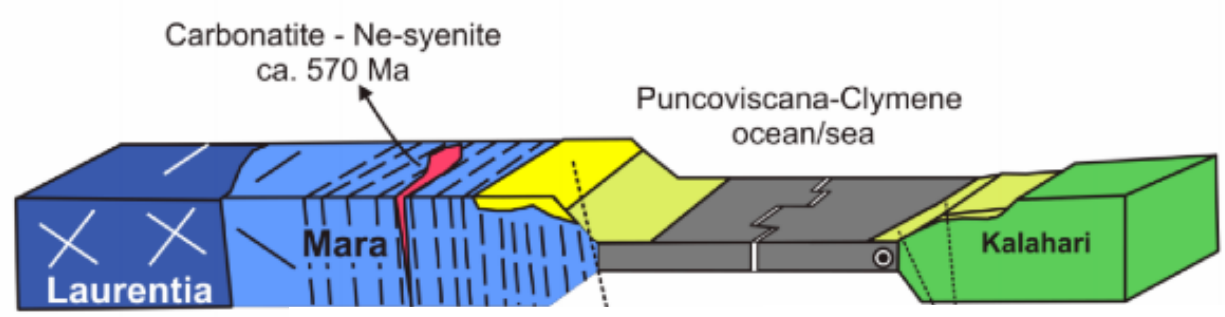

(b) 540-530 Ma. Opening of the lapetus Ocean and coeval Pampean oblique subduction

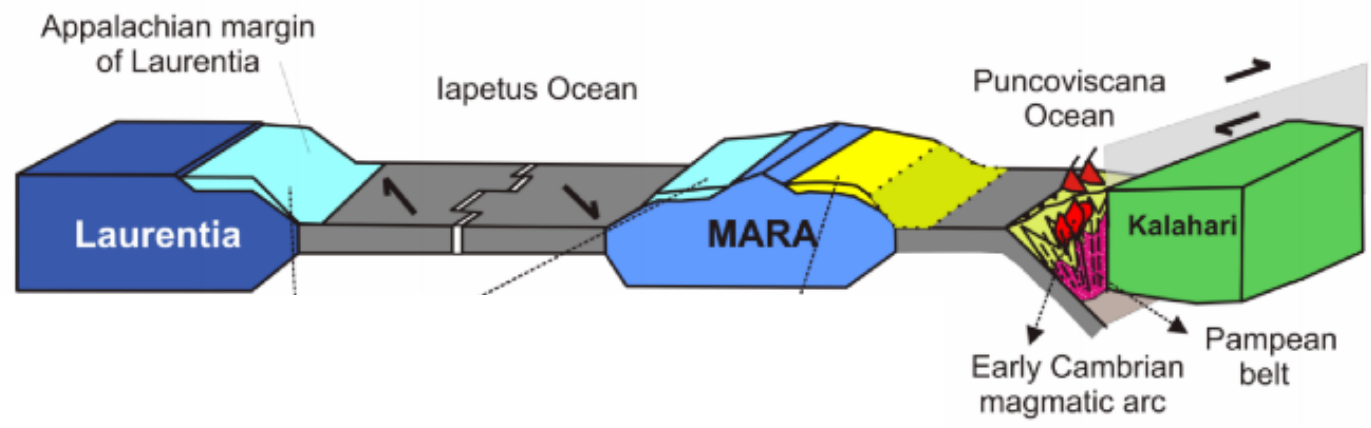

(c) 530-520 Ma. Pampean oblique collision

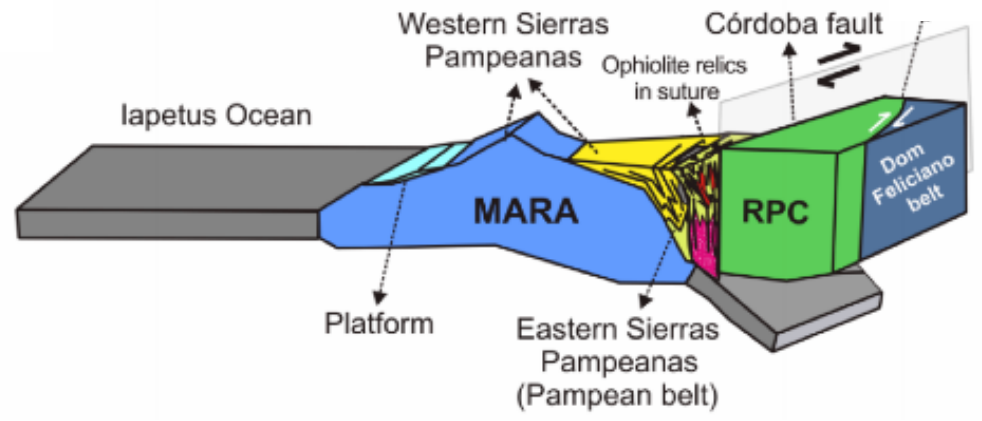

Figure 2: Proposed tectonic model for the MARA terrane modified from Rapela et al. 2016. RPC: Rio de la Plata Craton. 


\section{Geology of the Sierra de Maz}

The Sierra de Maz is situated between the allochthonous Devonian Precordillera terrane and the Ordovician Famatina continental magmatic arc (Figure 1B) and was first described by Kilmurray and Dalla Salda (1971) as three sub-parallel metamorphic domains trending NNW-SSE separated by first-order faults and shear zones (Figure 3). Foliation dips steeply to the east and metamorphic grade increases from west to east (Kilmurray and Dalla Salda, 1971; Casquet et al., 2006). From west to east, previous workers have divided the domain into distinct units: the Taco Complex, the Zaino Complex, the Maz Complex, and the Sierra de Ramaditas.

The El Taco Complex of the Sierra de Maz (Kilmurray and Dalla Salda, 1971), also referred to as the Western Domain by Casquet et al. (2008a), contains mostly marble, calc-silicate, and quartz-mica schists, with lesser amphibolite and orthogneiss. Titanite U-Pb ages of 443 and $431 \mathrm{Ma}$ (Lucassen and Becchio, 2003) and a garnet SmNd age of $301 \mathrm{Ma}$ (Porcher et al., 2004) were reported from the Taco Complex with no quantitative estimates of metamorphic conditions.

The El Zaino Complex lies structurally above the El Taco Complex and was described by Casquet et al. (2008a) as a succession of Fe-rich garnet-chlorite schists of unknown age. Porcher et al. (2004) described the Zaino Complex as a sequence of metasediment of variable bulk compositions containing schist, calc-silicate, amphibolite, and marble, although their descriptions came solely from observations within the adjacent Sierra de Espinal to the north (Figure 1B). There are no published ages from this unit and thermobarometry is lacking. 
The Maz Complex lies structurally above the Zaino Complex and is consists of mafic and pelitic gneiss, a Paleoproterozoic anorthosite massif, $\sim 845 \mathrm{Ma}$ and $~ 774$ Ma A-type granitoids, and $\sim 570$ Ma carbonatites (Casquet et al., 2008a; Casquet et al., 2008b; Colombo et al., 2009; Rapela et al., 2010). Lucassen and Becchio (2003) reported a titanite U-Pb age of $431 \mathrm{Ma}$ from a calc-silicate in the eastern portion of the Maz Complex. Casquet et al. (2006) recognized 1208 Ma metamorphic rims on zircon in orthogneiss and attributed them to Grenvillian metamorphism. Zircon cores from the same sample resulted in peak ages around 1700 and $1880 \mathrm{Ma}$ and were interpreted to represent a late Paleoproterozoic provenance age for metasediments of the Maz Complex (Casquet et al., 2006). Casquet et al. (2006) also estimated granulite P-T conditions of $780^{\circ} \mathrm{C}$ and $0.8 \mathrm{GPa}$ from a metabasite adjacent to the eastern orthogneiss. Porcher et al. (2004) reported three whole rock Sm-Nd ages of 1040, 969, and 462 Ma from within the the Maz Complex. Three P-T estimates made by Porcher et al. (2004) from within the Maz Complex span a range of conditions from $630-771{ }^{\circ} \mathrm{C}$ and 5 - 7 kbar, but lack individual uncertainty estimates with at least one analysis plotting outside of the kyanite stability field as reported in the sample assemblage. Lucassen and Becchio (2010) also reported scattered P-T estimates from within the Maz Complex that range from $650-800{ }^{\circ} \mathrm{C}$ and $0.5-0.9 \mathrm{GPa}$. These previous studies have not systematically examined metamorphic conditions and timing within the Maz Complex as it relates to the history of deformation.

The Sierra de Ramaditas is a lesser range to the immediate southeast of Sierra de Maz (Figure 3). Porcher et al. (2004) described Ramaditas as a sequence of garnetsillimanite migmatitic paragneiss, marble, and amphibolite and correlated the region 
with the El Taco Complex. Casquet et al. (2008) obtained a weighted mean U-Pb

zircon age of $442 \mathrm{Ma}$ from within Sierra de Ramaditas and correlated it with units in the northern Sierra de Espinal.

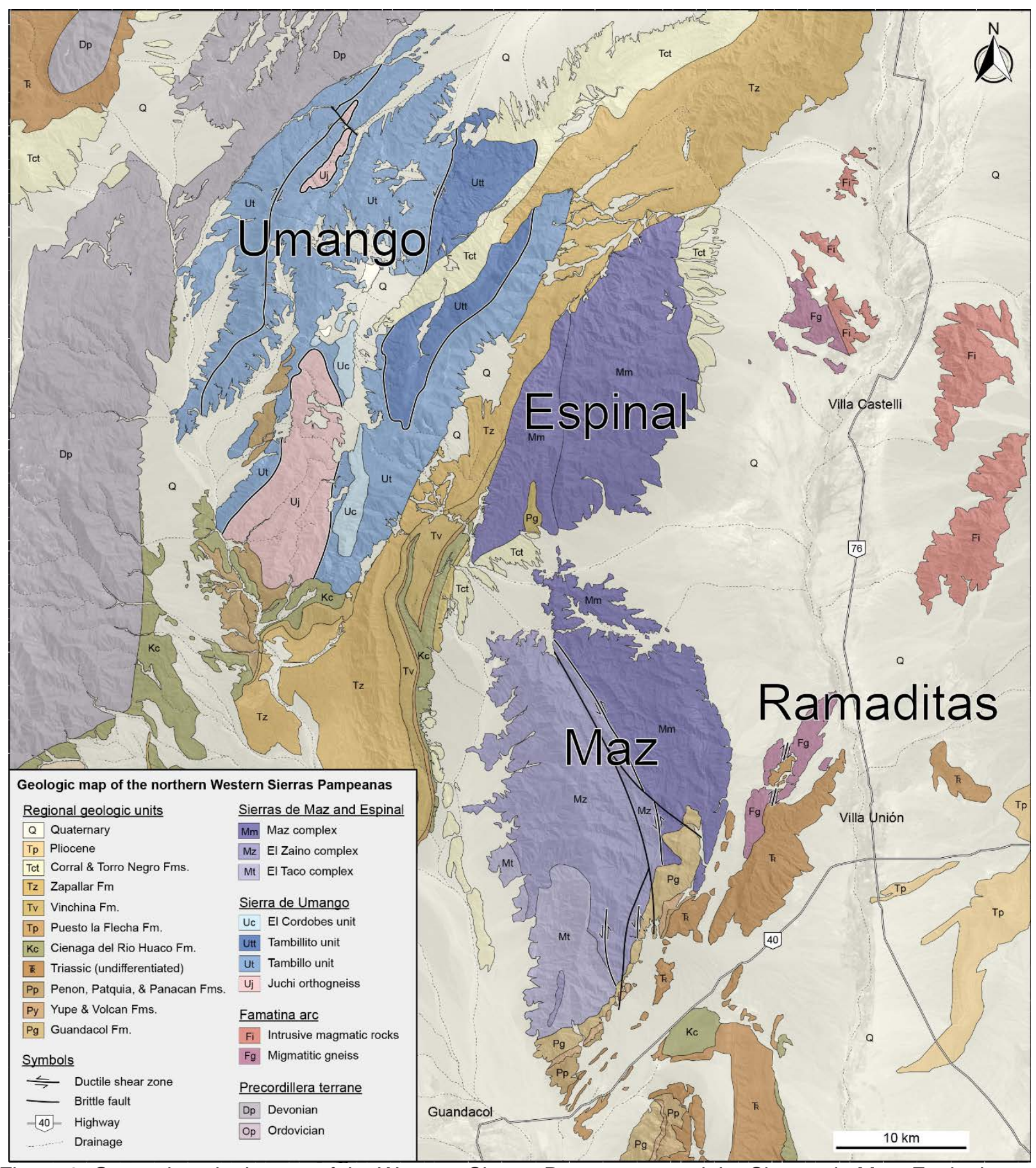

Figure 3: General geologic map of the Western Sierras Pampeanas and the Sierras de Maz, Espinal, Umango. The Sierra de Ramaditas is denoted by the map unit Fg (compiled and adapted after Meira et al., (2012) and references therein) 


\section{Lithologic Units}

This study follows the original naming convention established by Kilmurray and Dalla Salda (1971) with modifications based on observed differences in protolith, metamorphic assemblage, and metamorphic age (Figure 4). From west to east, we recognize four distinct units: the Taco Complex, the Zaino Complex, the Maz Complex, and the Ramaditas Complex of the Famatina arc (Figure 3).

The Taco Complex occurs only in the southwestern Sierra de Maz and consists of isoclinally folded schist, orthogneiss, paragneiss, phyllite, amphibolite, quartzite, and marble (Figure 3 and 5A). The boundary between the Taco Complex and the Zaino complex was not directly observed in this study. Pelitic assemblages of variable protolith contain Grt-Bt-Qtz $\pm M s \pm S i l \pm C h l$. Amphibolite layers range in thickness from sub- to meter-scale and contain the assemblage Amp-Qtz-Bt-Pl \pm Ms \pm Grt. The dominant foliation dips from $55^{\circ} \mathrm{E}$ to sub-vertical with multiple zones of grain size reduction throughout the unit.

Directly northeast from the Taco Complex lies the Zaino Complex, spanning almost the entire length of the Sierra de Maz (Figure 3). The eastern boundary of the Zaino Complex is defined by the NNW-SSE trending Maz shear zone. Casquet et al. (2008) described this unit as Fe-rich Grt-Chl schists (Figure 5B), however, we recognize additional metacarbonate, calc-silicate, amphibolite, and pelitic schist. Amphibolite is present on the sub-meter scale and contains the assemblage Qtz-Plg-Amp \pm Ms. Pelitic schists have variable assemblages that change systematically from west to east across the Zaino Complex (Fig 4?). In the most westerly regions of the Zaino Complex, schists contain the assemblage Qtz-Plg-Ms-Chl-Bt \pm Grt. Moving east, the dominant pelitic 
assemblage becomes Qtz-Plg-Ms-Bt-Grt (Figure 5C) before crossing into the most eastern portions where metapelites contain the assemblage Qtz-Plg-Ms-Grt-Bt-St (Figure 5D). The Zaino Complex is isoclinally folded with post-kinematic garnets growing over a steeply inclined NW-SE striking axial planar cleavage (Figure 4; Figure 5C). Foliation primarily dips eastward with stretched micas defining shallow lineations (Figure 4).

The Maz Complex extends eastward from the Maz shear zone to the termination of the range and has been divided into four parallel groups based on protolith differences (Figure 4). Immediately east of the Maz shear zone is the first subunit termed Mm1 that contains amphibolite, orthogneiss, and less common pelitic layers. Metapelites found nearest to the Maz shear zone contain the assemblage Qtz-PIg-MsSt-Grt with syn to post-kinematic garnet porphyroblasts. This unit is isoclinally folded. The next sub-parallel zone to the east, Mm2, is a sequence of paragneiss, amphibolite, and interleaved orthogneiss (Figure 5F). Paragneiss from Mm2 contains pre to synkinematic garnet with the assemblage Qtz-Plg-Ms-Bt-St-Grt-Chl \pm Ky (Figure 5E). Rare outcrops within Mm2 as well as Mm4 contain pre-kinematic garnet megacrysts several centimeters in diameter with chlorite rinds. Orthogneiss of Mm2 contains the assemblage Amp-Qtz-Bt-Plg-Ms-Gt with post kinematic garnet. Within Mm4 is massiftype anorthosite body interleaved within the dominant NNW-SSE foliation and labeled as Mm3 in Figure 4. Directly east of the anorthosite massif is the subunit Mm4, with the dominant lithologies being intermediate to mafic orthogneiss. Potassium feldspar bearing augen gneiss outcrops in multiple locations within $\mathrm{Mm} 4$ and can be seen both cutting and being deformed by the latest foliation event. Paragneiss assemblages in the 
most eastern portions of Mm4 contain pre-kinematic garnets and the assemblage QtzPlg-Ms-Bt-St-Grt-Sil-Kfs (Figure 5G).

Rocks of the Ramaditas Complex within the Sierra de Ramaditas lie unconformably below Triassic red beds (Figure 3). The unit consists of metacarbonate, migmatite, intermediate to felsic orthogneiss, amphibolites and metapelite. The unit is isoclinally folded and the dominant foliation dips to the east following the general trend of units within the Sierra de Maz. Weakly deformed felsic Kfs-Bt pegmatites cross cut the dominant NNW-SSE foliation. Paragneiss from the Ramaditas Complex contains the assemblage Grt-Bt-Kfs-Qtz-Plg-Bt \pm Ctd \pm Sil \pm Ms. 


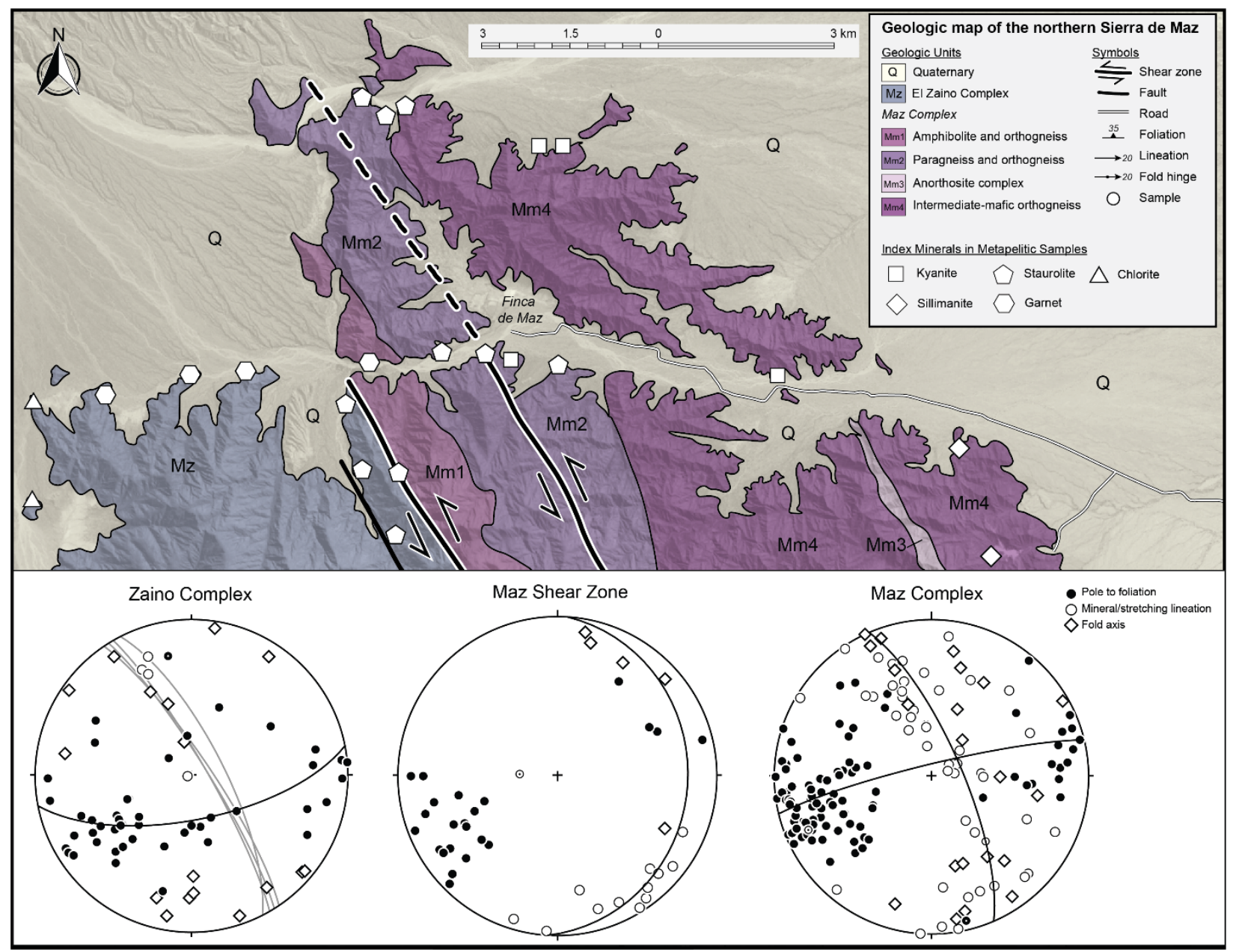

Figure 4 Geologic map of northern Sierra de Maz illustrating variation in metamorphic grade across the Zaino Complex, Maz shear zone, and the Maz Complex. Pelitic index minerals, denoted by various polygons, indicate an east to west inverted metamorphic gradient across the northern Sierra de Maz. Stereonets display poles to foliations, fold axes, and linations from within the Zaino and Maz Complexes as well as the Maz shear zone. Grey lines in the Zaino Complex stereonets are orientations of axial planar cleavage, black lines are calculated great circle fits to field measurements. 

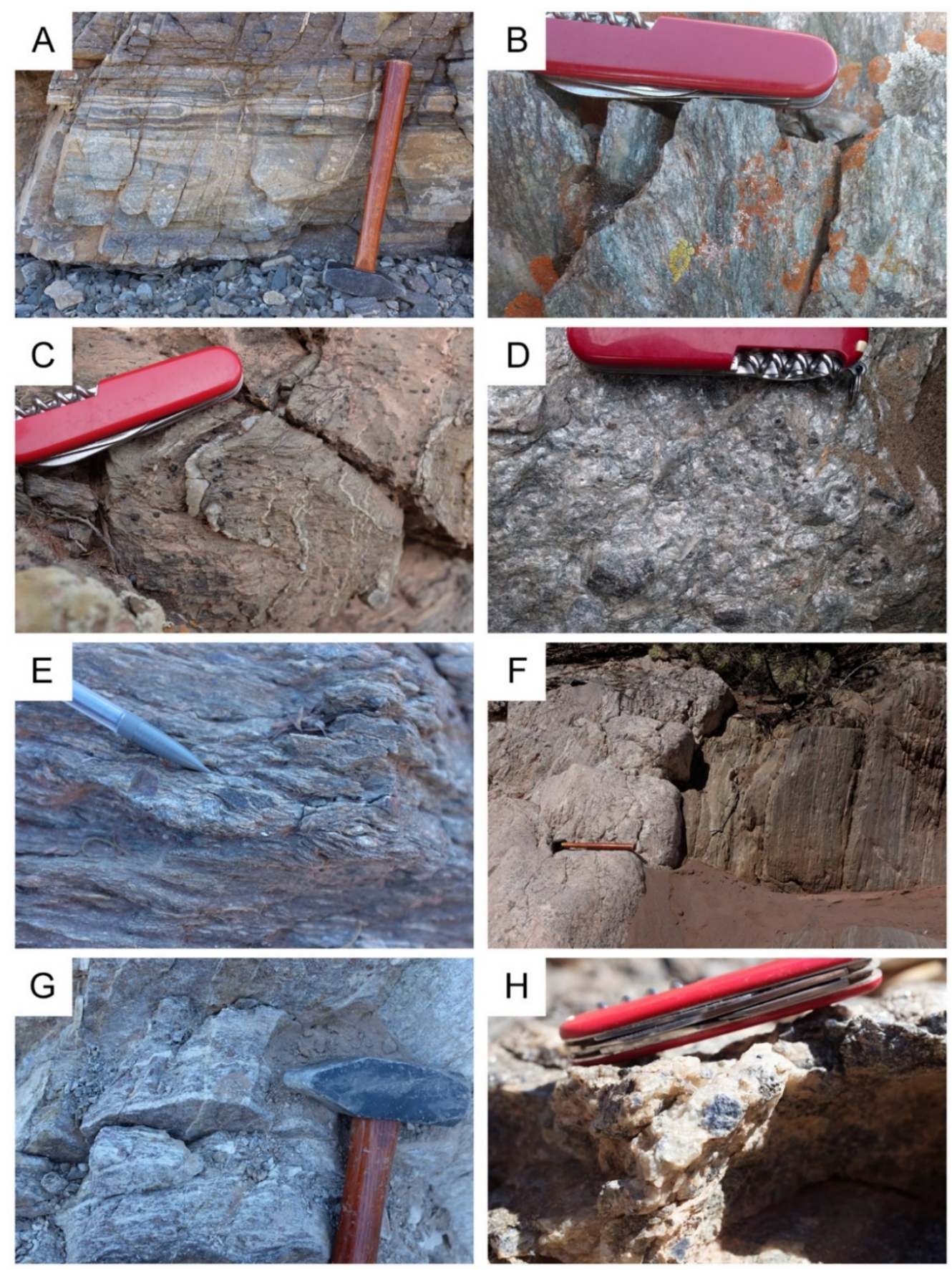

Figure 5: Outcrop photographs of units within the Sierra de Maz. Scales for photos are either a mechanical pencil, a $\sim 50 \mathrm{~cm}$ long rock hammer, or a $\sim 10 \mathrm{~cm}$ long pocket knife. A) Isoclinal folding and gneissic banding within units of the Taco Complex (sample AT-062). B) Chlorite schist of the Zaino Complex (sample AT-017). C) Post-kinematic euhedral garnets overgrowing axial planar cleavage within the Zaino Complex (sample AT-021). D) Qtz-Plg-Ms-Bt-Grt-St schist found within the most eastern exposures of the Zaino Complex. (sample AT-072). E) Pre- to syn-kinematic Qtz-Plg-Grt-Ms-Bt-St schist within subunit Mm2 of the Maz Complex. F) Paragneiss (right side of photo, darkly colored) and orthogneiss (left side of photo, lightly colored) within the Maz Complex subunit Mm2 (sample AT-068). G) granulite facies metapelitic outcrop within the Maz Complex subunit Mm4 (sample AT-028). H) Blue, pseudohexagonal cordierite grain found within the Sierra de Ramaditas. 


\section{Ductile Shear Zones}

Previous studies (Porcher et al., 2004; Casquet et al., 2006) have recognized the La Vibora brittle fault as the boundary between El Taco and El Zaino Complexes, however no previous work has related ductile shearing within Sierra de Maz to the metamorphic history of the region. This study recognizes the Maz shear zone as a major structural boundary separating the Zaino Complex in west from and the Maz Complex in the east. The Maz shear zone is a meter-scale ultramylonite zone of reverse-sinistral shear (Houlihan et al., 2017) that trends NNW-SSE and dips steeply east (Figure 6A; Figure 4). Lineations are shallow to sub-horizontal and are defined by stretched mica, quartz, and aligned amphibole. Even though the ultramylonite Maz and Finca shear zones are delineated on the map as a discrete line, those lines mark the regions of highest strain, but deformation extends over a zone of more than $7 \mathrm{~km}$ wide (Figure 6B).

While the Maz shear zone is a prominent mylonite-ultramylonite zone, smaller regions of mylonite and ultramylonite occur within the Maz Complex. One such region, located within the subunit Mm2 of the Maz Complex is referred in this study as the Finca shear zone. This sub-meter ultramylonite is concentrated within metapelite and orthogneiss around a region of amphibolite. Mylonitic fabrics in the Finca shear zone are sub-parallel to Maz shear zone with similar shallow lineations and a sinistral shear sense (Figure 6C). Pelitic units adjacent to this shear zone contain coarse, zoned garnet of varying size that show pre, syn, and post-kinematic relationships to the most recent shear fabric. 
The Ramaditas shear zone is a meter-scale mylonite within the Sierra de Ramaditas that has not been described by previous studies of this range. The trend of the shear zone is roughly N-S with foliation steeply east dipping to sub vertical. Lineations are poorly preserved within the main mylonite zone, but are generally observed to be oblique. The shear sense is dominantly top-to-the-west thrust with a locally weakly developed right-lateral shear sense indicators. A coarse, felsic dike with centimeter sized grains of Kfs-Qtz-Ms can be seen cutting across the main mylonite zone and is also boudinaged and deformed within the mylonitic foliation (Figure 6D). This relationship suggests that shear is pre- to syn-tectonic with respect to the felsic dike. Leucocratic melts within mafic orthogneiss near the main mylonite zone contain the assemblage Qtz-Kfs-Grt while pelitic units near the shear zone contain the assemblage Qtz-Kfs-Bt-Sil. 



Figure 6: Outcrop photographs of sheared units within the Sierra de Maz. Scales for photos are either $\sim 50 \mathrm{~cm}$ long rock hammer or a $\sim 10 \mathrm{~cm}$ long pocket knife. A) Steeply dipping ultramylonite zone from the Maz shear zone (proximal to sample AT-076). B) A relict orthogneiss fabric from the Maz Complex subunit Mm2 that is boudinaged by foliation related to the Maz shear zone (sample AT-015). C) Half meter utramylonite from the Finca shear zone within the Maz Complex subunit Mm2 (sample AT-068). D) Steeply dipping Ramaditas shear zone with coarse Kfs dike that both cross-cuts and is boudinaged by the shear zone. 


\section{Summary}

Pelitic index minerals suggest an amphibolite to granulite facies inverted sequence is preserved within the Maz Complex with pelitic index minerals grading from staurolite to kyanite and eventually sillimanite + potassium feldspar from west to east and structurally upward. The presence of the low-pressure phase cordierite (Figure $5 \mathrm{H}$ ) within the Sierra de Ramaditas points to significantly different metamorphic conditions in this unit compared to high-pressure kyanite-bearing assemblages within the Sierra de Maz. Outcrop geology suggests that foliation development related to the Maz shear zone post-dates much of the metamorphic development within the Maz Complex and is a major event in the development of fabrics related to the Zaino Complex. This notion is most strongly supported in relict fabrics and assemblages observed within Maz Complex subunit Mm2 (Figure 6B) that are otherwise absent from the Zaino Complex. Sinistral kinematics and shallow lineations within steeply dipping foliations suggest that movement along the Maz shear zone accommodated transpressive deformation. 


\section{Petrology and Thermobarometry}

Samples were collected along a west-to-east transect across the Sierras de Maz (Figure 4; Table 1; Table 2) and Ramaditas in order to (1) identify the metamorphic conditions of the various lithological units, (2) compare differences in the metamorphic conditions across major structures, and (3) compare the metamorphic conditions between the Sierra de Maz and Sierra de Ramaditas. Mineral compositions were determined by electron probe microanalysis (EPMA) with a Cameca SX-100 at UC Davis. Operating conditions including spot sizes and accelerating voltages are reported in DR1 of the digital appendix. Temperature and pressure estimations were determined with multiequilibirum thermobarometry using average PT method in THERMOCALC (Powell and Holland, 1994) and are summarized in Figure 7 and Table 3.

\section{Taco Complex}

High grade pelitic schist from the EL Taco Complex contains Grt-Bt-Ky-Sil-PlgKfs-Qtz (Figure 8A). Samples from the El Taco Complex were not analyzed with EPMA, thus only qualitative estimates of temperature and pressure can be made. The presence of sillimanite and K-feldspar along with the absence of muscovite implies that this rock is beyond the second sillimanite reaction. A lack of cordierite and orthopyroxene within this sample places pressure estimates between 4-12 kilobars and temperature estimates between $750-900^{\circ} \mathrm{C}$ (Spear and Cheney, 1999). 


\section{Zaino Complex}

Pelitic schist assemblages from the Zaino Complex vary systematically from west to east across the unit, consistent with an increase in metamorphic grade. The most western outcrops contain abundant chlorite (Figure 8B) and transition into garnetbearing assemblages over a structural distance less than 2 kilometers. Average PT calculations were determined for three pelitic assemblages using garnet rim and matrix mineral compositions with Qtz and $\mathrm{H}_{2} \mathrm{O}$ in excess. Sample AT-021a from the Zaino Complex contains the assemblage Grt-Bt-Ms-Plg-Qtz (Figure 8C). The primary foliation is an axial planar cleavage defined by alternating mica-rich and quartzo-feldspathic layers and cut by post-kinematic garnet. Garnet is compositionally zoned with a bellshaped XSps profile and XMg concentrations that increase from core to rim suggestive of a single phase of prograde garnet growth (Figure 9A; Figure 10A). Garnet rim compositions paired with matrix $\mathrm{Ms}, \mathrm{Bt}$, and Plg record metamorphic conditions of $8.2 \pm$ 1.7 kbar and $564 \pm 91^{\circ} \mathrm{C}$. Sample AT-021b contains the assemblage Grt-Bt-Plg-QtzAmp with post-kinematic garnets that similarly cut across an axial planar cleavage. Garnet rim compositions and matrix $\mathrm{Bt}, \mathrm{Ms}$, and Plg record metamorphic conditions of $7.3 \pm 1.6$ kbar and $489 \pm 71{ }^{\circ} \mathrm{C}$. Sample AT-017 was the easternmost sample analyzed from the Zaino Complex and contains the assemblage Grt-Bt-Ms-Plg-Chl-Qtz. Garnet rim compositions and matrix $\mathrm{Bt}, \mathrm{Ms}$, $\mathrm{Plg}$, and $\mathrm{Chl}$ record metamorphic conditions of 8.2 $\pm 1.4 \mathrm{kbar}$ and $575 \pm 14{ }^{\circ} \mathrm{C}$. The most eastern metapelitic outcrops of the Zaino Complex contain the assemblage Grt-St-Bt-Ms-Plg-Qtz, although these samples were not analyzed for PT conditions, pelitic index assemblages qualitatively suggest that temperatures for this region were $550-650^{\circ} \mathrm{C}$ (Spear and Cheney, 1989). Taken 
together, the three samples analyzed using EPMA are interpreted to represent peak metamorphic conditions reached within the Zaino Complex after deformation.

\section{Maz Shear Zone}

Two metapelites and one amphibolite were collected from within the Maz shear zone and analyzed for pressure and temperature conditions. Syn to post-kinematic garnets from the Maz shear zone are Fe-rich (XAlm >0.70) with discrete zones apparent in major element maps (Figure 9B). Chemical zoning analysis reveal diffusively zoned garnets that are lacking in rim-ward increases in spessartine content. Fig 10b? Sample AT-076 from within the Maz shear zone contains the assemblage Grt-St-Bt-Ms-PI and resulted in average PT calculations of $7.7 \pm 1.1$ kbar and $653 \pm 27{ }^{\circ} \mathrm{C}$ (Figure $8 \mathrm{E}$ ). Sample AT-073 from $0.5 \mathrm{~km}$ northwest along strike contains the assemblage Grt-St-BtMs-Plg-Qtz and resulted in average PT conditions of $8.3 \pm 1.4$ kbar and $602 \pm 90{ }^{\circ} \mathrm{C}$. Sample AT-015c is a mafic assemblage of Grt-Bt-Plg-Amp-Qtz with post-kinematic garnets and aligned amphibole defining a mylonitic foliation that deforms and older fabric (Figure 5B; Figure 8F). The sample records average PT conditions of $8.6 \pm 2$ kbar and $652 \pm 153^{\circ} \mathrm{C}$. These estimates are interpreted to reflect peak metamorphic conditions during deformation on the Maz shear zone. 


\section{Maz Complex}

Schist and gneiss from the Maz Complex exhibit a range of assemblages with index minerals indicating an increase in metamorphic grade from west to east across the unit (Figure 4). Twelve samples along an east-west transect of the Maz Complex were analyzed for pressure and temperature conditions (Table 2). The most westerly sample nearest to the Maz shear zone ultramylonite, sample AT-066, contains prekinematic garnets in the assemblage Grt-St-Bt-Ms-Plg-Qtz. Garnet rim compositions combined with matrix Bt, Ms, and Plg record metamorphic conditions of $9.0 \pm 1.5 \mathrm{kbar}$ and $706 \pm 34{ }^{\circ} \mathrm{C}$. Roughly 3 kilometers east of the Maz shear zone, sample AT-068 from within the Finca shear zone contains the assemblage Grt-St-Bt-Ms-Plg-Qtz. Garnets are pre-kinematic (Figure 8G) and possess irregular major element zoning, including elevated $\mathrm{Mn}$ and $\mathrm{Ca}$ along garnet fractures possibly from post-garnet fluid infiltration (Figure 9C). Rim to rim garnet compositional zoning generally reflects diffusive zoning with symmetrical increases in spessartine content suggesting multiple garnet growth events are preserved in this rock (Figure 10C). Garnet rim compositions paired with matrix St, Bt, Ms, and Plg compositions result in average PT conditions of $7.2 \pm 1.1 \mathrm{kbar}$ and $694 \pm 27^{\circ} \mathrm{C}$. Less than a kilometer east of the Finca shear zone, sample AT-070 contains the assemblage Grt-Ky-St-Bt-Ms-Plg, with retrograde chlorite and resulted in average PT conditions of $6.6 \pm 0.9$ kbar and $624 \pm 17^{\circ} \mathrm{C}$ (Figure $\left.8 \mathrm{H}\right)$. In the most eastern portions of the Maz Complex, sample AT-028 contains a metapelitic granulite facies assemblage of Grt-Sil-Bt-Kfs-Plg-Qtz (Figure 8I). Garnets are prekinematic and lack major element zoning in major element maps (Figure 9E) with rim to rim chemical analysis showing homogenized XSps compositions and weakly zoned 
XMg (Figure 10D). Maximum XMg garnet rim compositions paired with matrix Bt, Kfs, and Plg resulted in average PT conditions of $10.3 \pm 1.6 \mathrm{kbar}$ and $876 \pm 56{ }^{\circ} \mathrm{C}$. Mafic orthogneiss from the eastern portions of the Maz Complex also contains the assemblage Grt-Cpx-Scp (Figure 8J) consistent with granulite facies metamorphic conditions.

\section{Ramaditas Complex}

Several samples were collected from the Sierra de Ramaditas, however only a single metapelite contained enough relevant phases for PT calculations. Garnets from Ramaditas are pre-kinematic, Fe-rich (XAlm >0.70), and major element maps lacking significant compositional zoning (Figure 8K; Figure 9E). Rim to rim compositional zoning however, shows rimward increases in XSps content and decreases in XMg that indicate diffusive cooling from high temperatures (Figure 10E). Sample AT-047 contains the assemblage Cd-Grt-Bt-Plg-Qtz and resulted in average PT conditions of $5.5 \pm 1.5 \mathrm{kbar}$ and $856 \pm 160^{\circ} \mathrm{C}$. Additional samples collected from within the Sierra de Ramaditas have the assemblage Grt-Sil-Bt-Plg-Qtz (Figure 8L) but were not analyzed for average PT conditions. The presence of stable cordierite within metapelitic outcrops indicates that high temperatures occurred at anomalously low pressure when compared with metapelitic assemblages from the Sierra de Maz (Figure 7). 


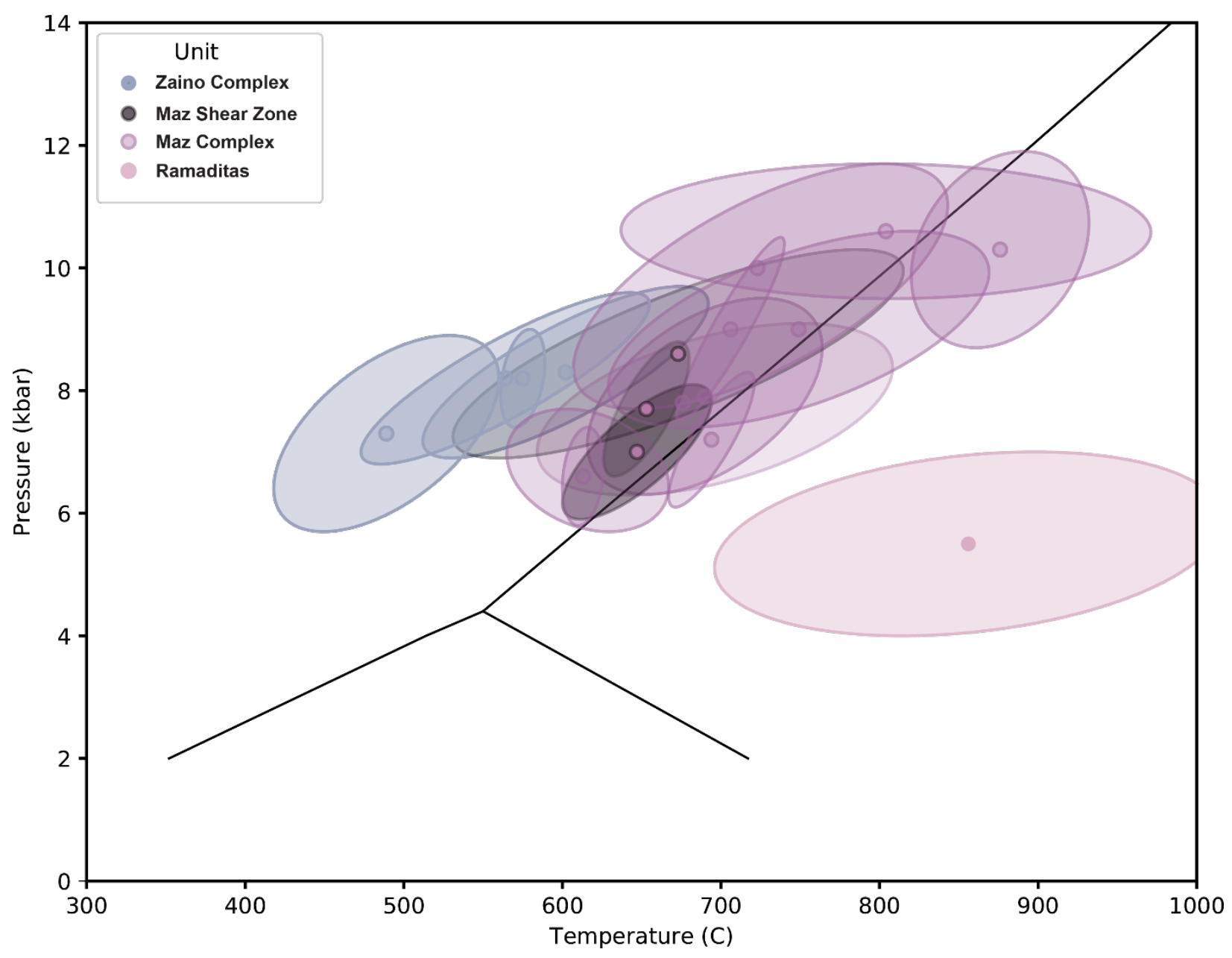

Figure 7: Pressure-temperature estimates and associated uncertainties for all samples analyzed from the Sierra de Maz and Sierra de Ramaditas. Conditions across the Sierra de Maz most closely reflect a Barrovian progression from west to east. The single analysis at anomalously higher temperatures and lower pressures than the rest of the data comes cordierite-bearing assemblages of the Sierra de Ramaditas. 

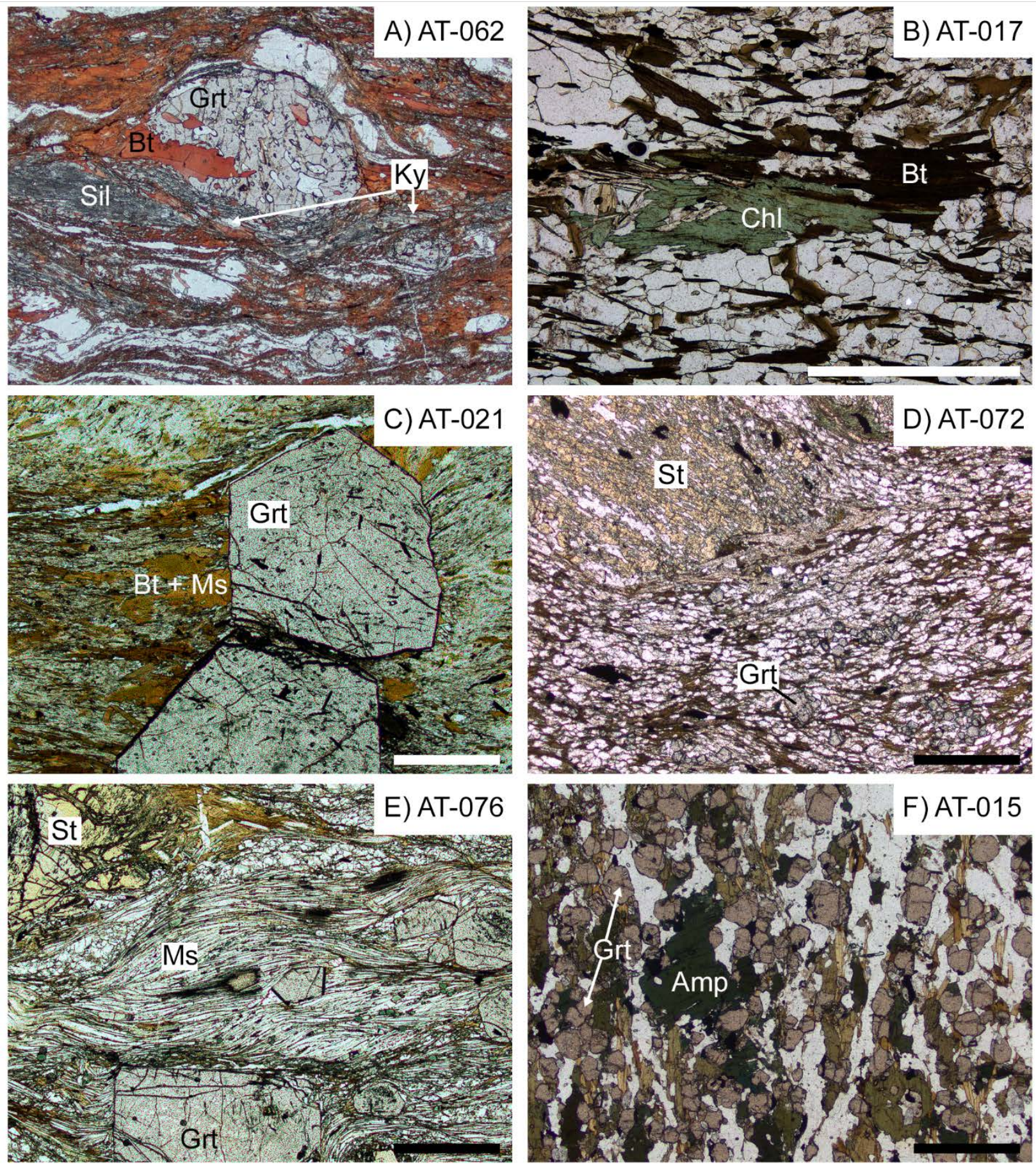

Figure 8: Photomicrographs of mineral assemblages from the Sierras de Maz and Ramaditas. Black and white scale bars in the bottom right corners of each photo are $1 \mathrm{~mm}$ in length. A) Sil-Grt from the El Taco Complex. B) Bt-Chl schist from the Zaino Complex. C) Post-kinematic garnets from the Zaino Complex and the assemblage Grt-Bt-Ms-Plg. D) Grt-St-Bt schist from eastern units within the Zaino Complex. E) Grt-St-Ms-Plg-Bt assemblage from a metapelite near the Maz shear zone exhibiting syn to post-kinematic garnets. F) Mafic orthogneiss with the assemblage Grt-Bt-Ms-Amp just east of the Maz shear zone. 

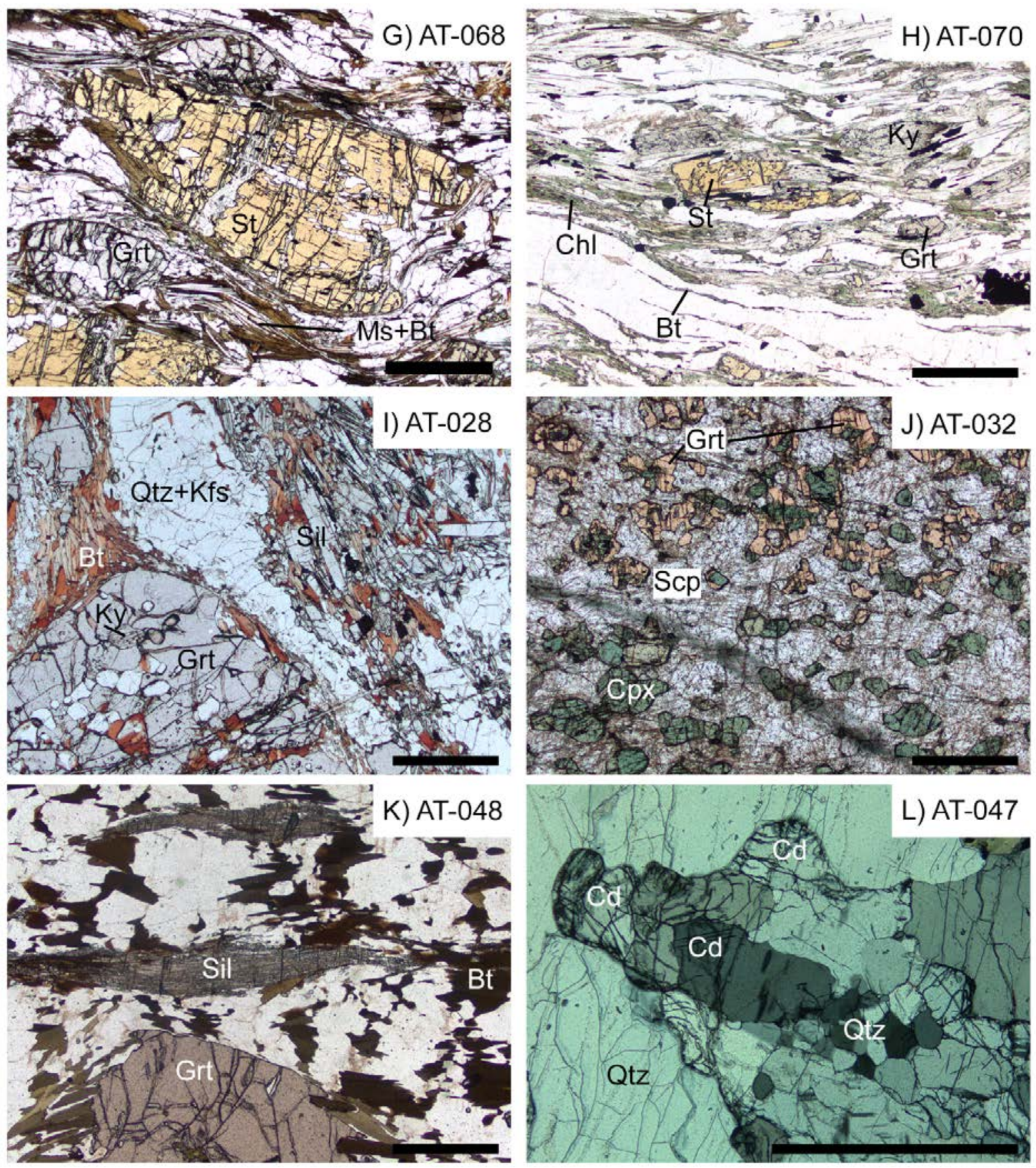

Figure 8 (continued): Photomicrographs of mineral assemblages from the Sierras de Maz and Ramaditas. Black and white scale bars in the bottom right corners of each photo are $1 \mathrm{~mm}$ in length. G) Grt-St-Bt-PlgMs schist near the Finca shear zone of the Maz Complex. H) Grt-Ky-Bt-Plg-Ms schist with retrograde chlorite less than a kilometer east of the Finca shear zone. I) Eastern Maz Grt-Bt-Ms-Sil-Plg-Kfs gneiss with an inclusion of kyanite preserved within a relict garnet. J) Orthogneiss from the eastern units of the Maz Complex containing the assemblage Grt-Scp-Amp. K) Grt-Sil-Bt gneiss from the Ramaditas Complex. L) Cordierite from the Sierra Ramaditas with characteristic fractures that radiate from grain boundaries and terminate within interior portions of each grain. Fracture patterns and subtle twinning distinguish cordierite from quartz and feldspar. 

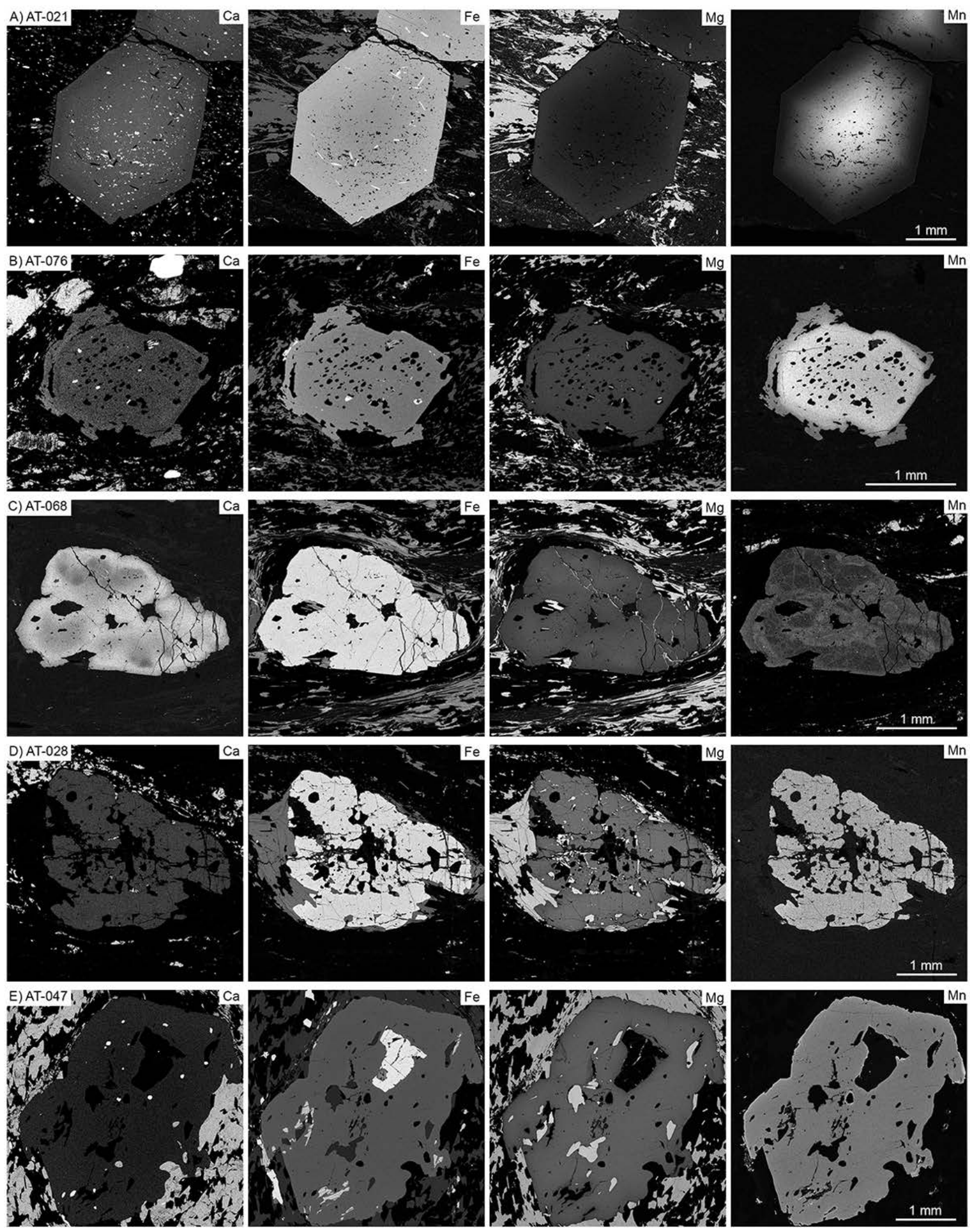

Figure 9: Zoning patterns of garnets chosen for combined thermobarometry and Lu-Hf geochronology. Light colors correspond to regions of high concentration. 

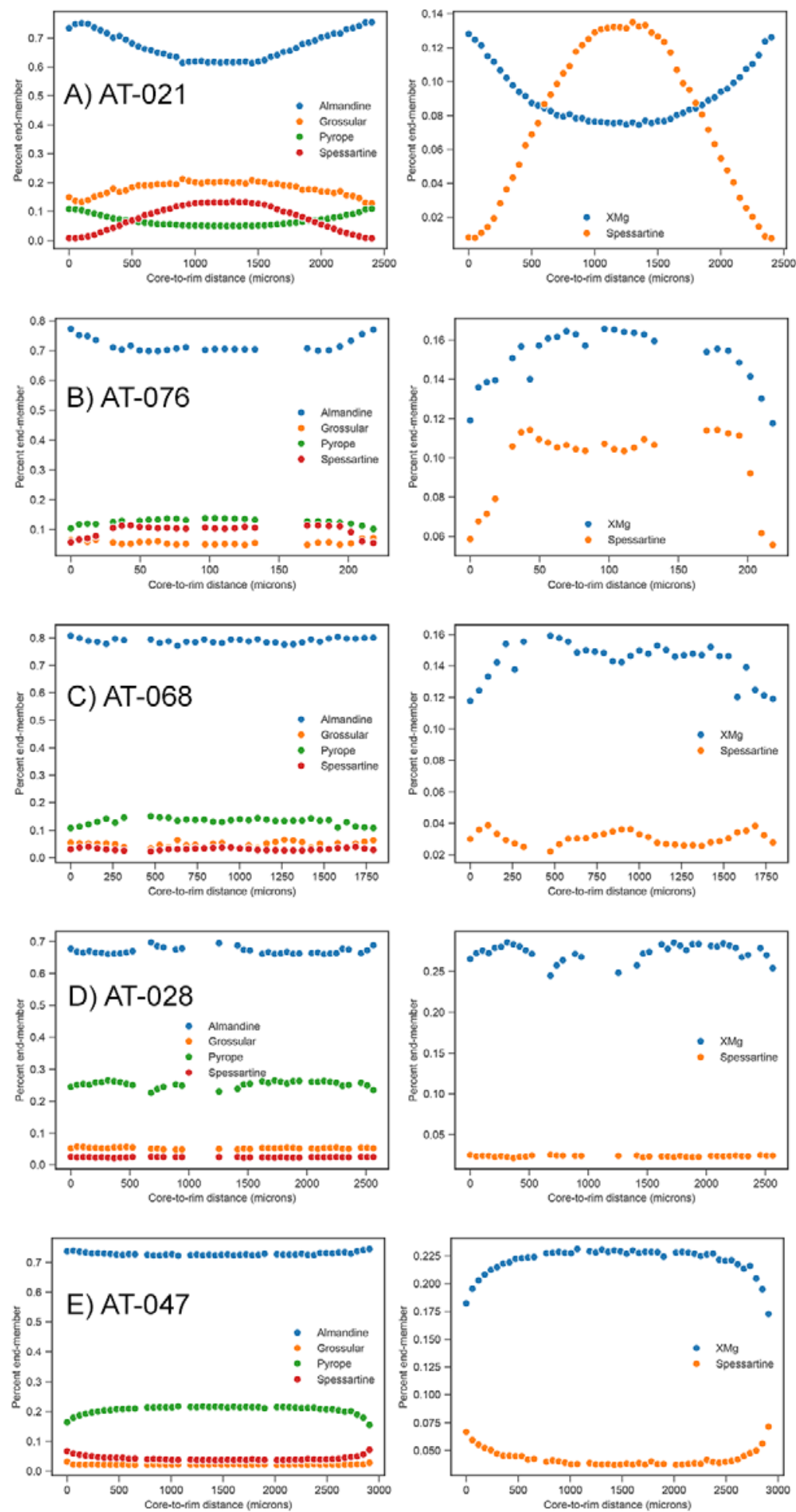

Figure 10: Figures within the left column depict garnet end-member compositions at given points along a transect. Figures in the right column depict elemental ratios at any given point. $(\mathrm{XMg}=\mathrm{Mg} / \mathrm{Fe}+\mathrm{Mg}$, Spessartine $=\mathrm{Mn} / \mathrm{Fe}+\mathrm{Mg}+\mathrm{Mn}+\mathrm{Ca})$. 


\section{Garnet Lu-Hf Geochronology}

Garnet-whole rock Lu-Hf ages for all samples were determined at Washington State University following the procedure outlined by Mulcahy et al. (2014). Garnet porphyroblasts were separated by hand crushing, magnetic separation, and handpicking of individual grains. The concentrations of Lu and Hf were determined by isotope dilution with uncertainties estimated to be better than $0.5 \%$. Uncertainties in ${ }^{176} \mathrm{Lu} /{ }^{177} \mathrm{Hf}$ for the purposes of regression and age calculations are estimated at $0.5 \%$. Reported errors on ${ }^{176} \mathrm{Hf} /{ }^{177} \mathrm{Hf}$ represent within-run uncertainty expressed as $2 \sigma$ standard error. Estimated total uncertainty on individual ${ }^{176} \mathrm{Hf} /{ }^{177} \mathrm{Hf}$ measurements for regressions and age calculations is $0.01 \%$. Ages were calculated with the ${ }^{176} \mathrm{Lu}$ decay constant values of Scherer et al. (2001) and Söderlund et al. (2004) and are reported with the associated 95\% confidence interval. Concentrations and isotopic data for garnet Lu-Hf isochrons are listed in Table 4.

Rim to rim lutetium concentrations were determined by laser ablation inductively coupled plasma mass spectrometry (LA-ICPMS) in the AMSEC facilities at Western Washington University using an Agilent 7500ce ICPMS with a New Wave UP-213AS laser ablation accessory utilizing a 213nm UV Nd:YAG class IV laser. Time-resolved spectra with a $1 \mathrm{~ms}$ integration were collected using a $55 \mu \mathrm{m}$ diameter spot size. Working acquisition time was 120 seconds, including 30 seconds of background, and 90 seconds of sample ablation. All analyses used a $1500 \mathrm{~W}$ forward power, a $10 \mathrm{~Hz}$ repetition rate, a $13.7 \mathrm{~J} / \mathrm{cm}^{2}$ fluence, and a carrier gas flow rate of $400 \mathrm{~mL} / \mathrm{min}$. Samples were calibrated to NIST610 values determined by Jochum et al. (2011), using an internal standard of aluminum determined by SEM analysis. Data were reduced using 
the software GLITTER (van Achterburgh et al., 2000) to avoid ablated inclusions within garnet spots.

\section{Zaino Complex}

A garnet-whole rock Lu-Hf isochron obtained from a Grt-Bt-Ms-Qtz-Plg metapelite (AT021a) of the Zaino Complex resulted in an age of $423 \pm 10 \mathrm{Ma}$ (MSWD $=4.6$ ) (Figure 11A). Garnet from this sample are euhedral, post-kinematic to axial planar cleavage, and preserve prograde growth zoning (Figure 7C, 8A, 9A). Lutetium is concentrated within the cores of garnet porphyroblasts and systematically decreases towards the rim consistent with a single generation of garnet growth (Figure 12A). Garnets from this sample are bimodal in size with grains either larger than $>2 \mathrm{~mm}$ or between 1-2mm. The smaller grain size fraction had higher ${ }^{176} \mathrm{Lu} /{ }^{177} \mathrm{Hf}$. Despite the apparent size dependency of parent daughter ratios, the high MSWD and bell-shaped Mn and Lu profiles suggest a single period of protracted garnet growth (Kohn, 2009). The age from this sample is interpreted to date garnet growth in the Zaino Complex as result of burial along the Maz shear zone.

\section{Maz Shear Zone}

Two samples were collected and analyzed from within the Maz shear zone. Sample AT-076b, a Grt-St-Ms-Plg-Bt schist within the Maz shear zone produced a garnet-whole rock Lu-Hf isochron of $429 \pm 5 \mathrm{Ma}(\mathrm{MSWD}=2.6)$ (Figure 11B). Garnets 
from this sample are pre- to syn-kinematic with respect to the Maz shear zone (Figure 7E, 8B, and 9B). Lutetium distribution in this sample does not have a central peak and is concentrated on the rims of garnets, implying the age is biased towards the youngest period of garnet growth. Garnets from a mafic Grt-Bt-Plg-Amp orthogneiss (AT-015c) are post-kinematic with respect to the Maz shear zone and resulted in a Lu-Hf isochron of $428 \pm 9 \mathrm{Ma}$ (MSWD=5.6) (Figure 11C). These two ages are interpreted to represent the age of garnet growth during the deformation along the Maz shear zone.

\section{Maz Complex}

Two metapelites were sampled from the Maz Complex along a transect east from the Maz Shear zone. Resultant isochrons from samples AT-068 and AT-028 contained significant scatter and did not result in clear age interpretations. The oldest age calculated from sample AT-068 comes from a three-point isochron at $759 \pm 54$ Ma while the youngest calculated age is $591 \pm 59 \mathrm{Ma}$. Sample AT-028 produced a less scattered isochron with an oldest age of $1074 \pm 6.4 \mathrm{Ma}$ and a youngest age of $1030.9 \pm 6.2 \mathrm{Ma}$. The scattered Lu-Hf ratios and major and trace element zoning in the two samples suggest they did not remain a closed system and/or experienced multiple metamorphic events. 


\section{Ramaditas}

One Grt-Sil-Bt-Plg-Qtz gneiss, sample AT-047b, was chosen from within the Sierra de Ramaditas and produced a scattered isochron with an oldest age of $461 \pm 1.7$ Ma and a youngest age of $449 \pm 1.6 \mathrm{Ma}$ (Figure 11F). Lutetium zoning from this sample reflects a central peak, and asymmetric increases of lutetium towards each rim (Figure 12E). Despite the relative scatter in the produced isochron, this sample is clearly distinct from the $\sim 420-430$ Ma ages in the Zaino Complex and Maz shear zone and $>591 \mathrm{Ma}$ ages found within the Maz Complex. The garnet age of 461-449 Ma is interpreted to bracket peak metamorphism within the Sierras de Ramaditas. 

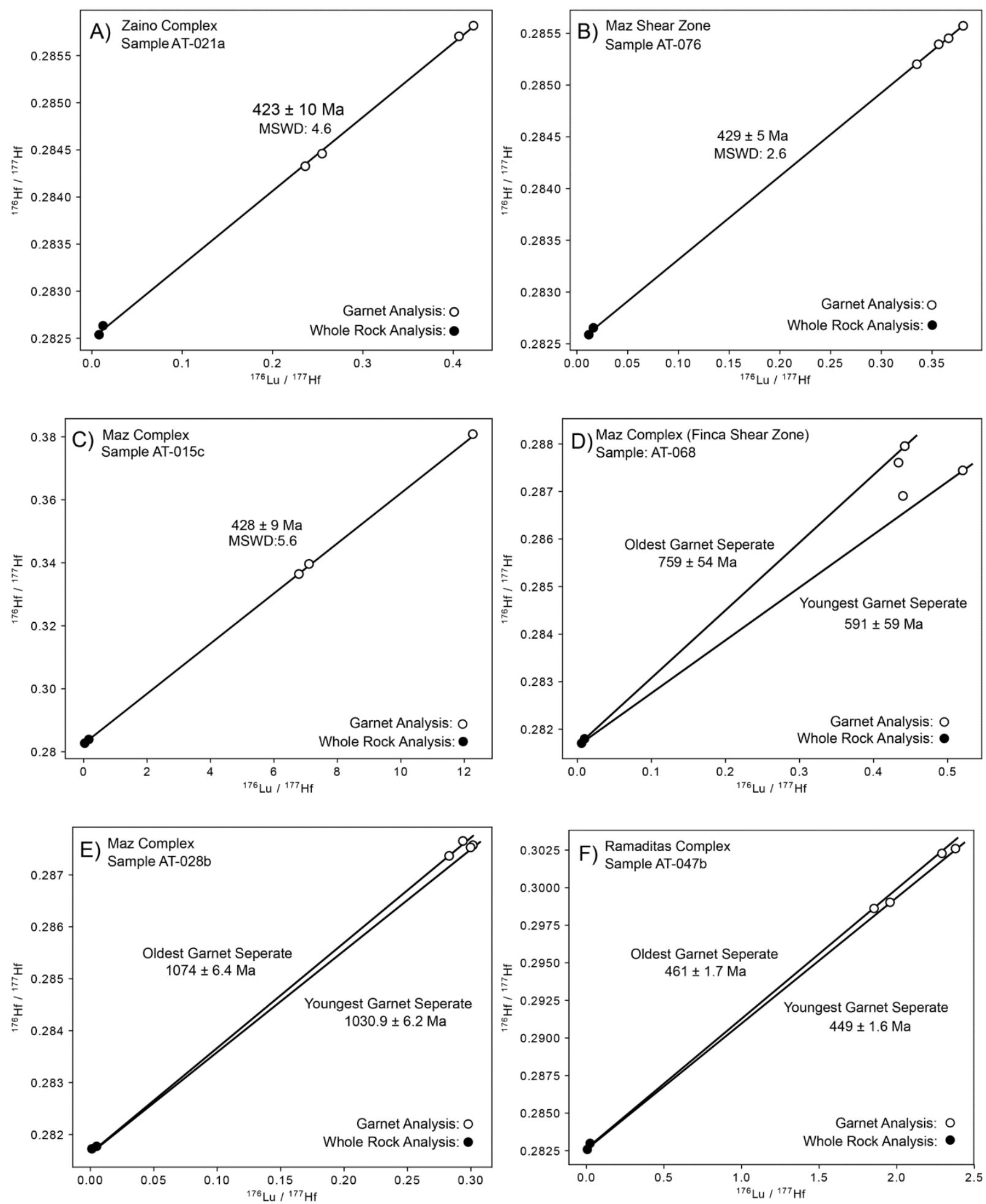

Figure 11: Garnet Lu-Hf ages. A) Lu-Hf isochron for sample AT-021. B) Lu-Hf isochron for sample AT076. C) Lu-Hf isochron for sample AT-015. D) Scattered Lu-Hf ratios of sample AT-068. E) Scattered Lu$\mathrm{Hf}$ ratios of sample AT-028. F) Scattered Lu-Hf ratios of sample AT-047. 
A) AT-021 [Lu] Rim-Rim

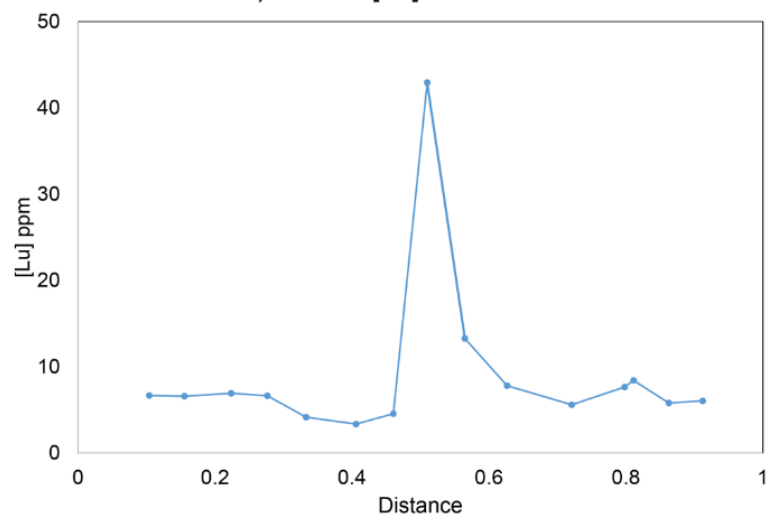

C) AT-068 [Lu] Rim-Rim

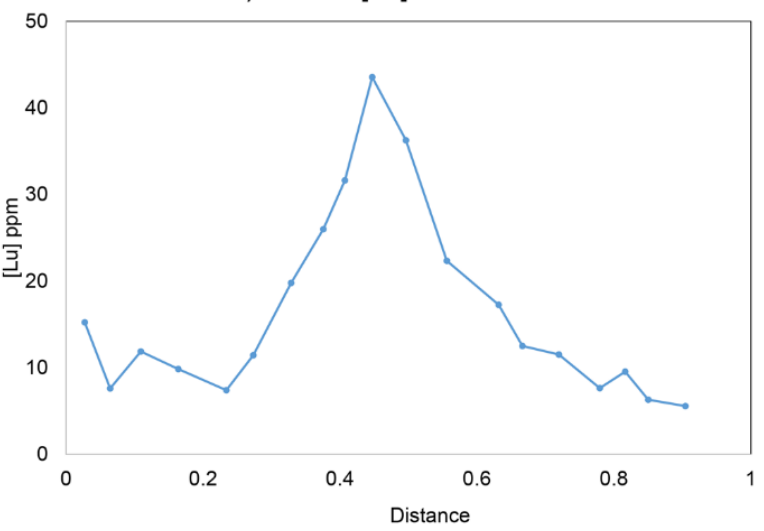

E) AT-047 [Lu] Rim-Rim

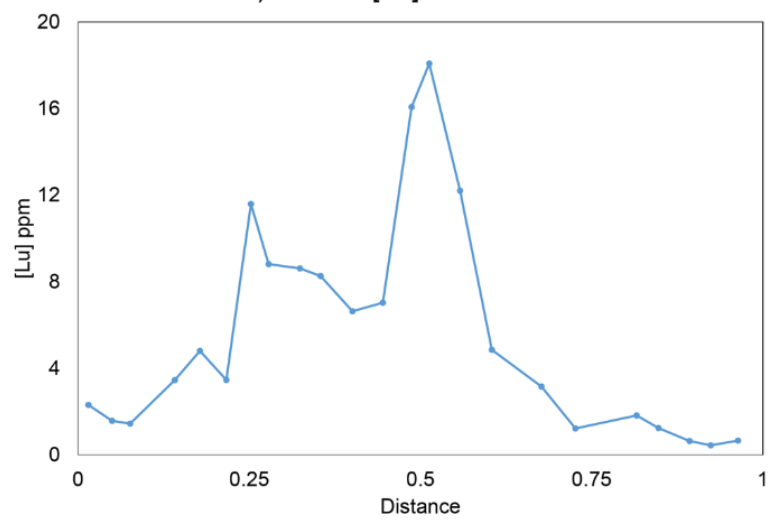

B) AT-076 [Lu] Rim-Rim

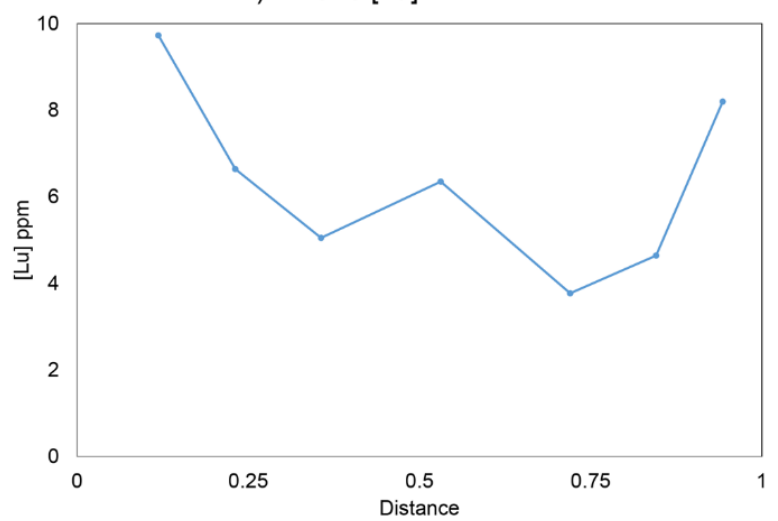

D) AT-028 [Lu] Rim-Rim

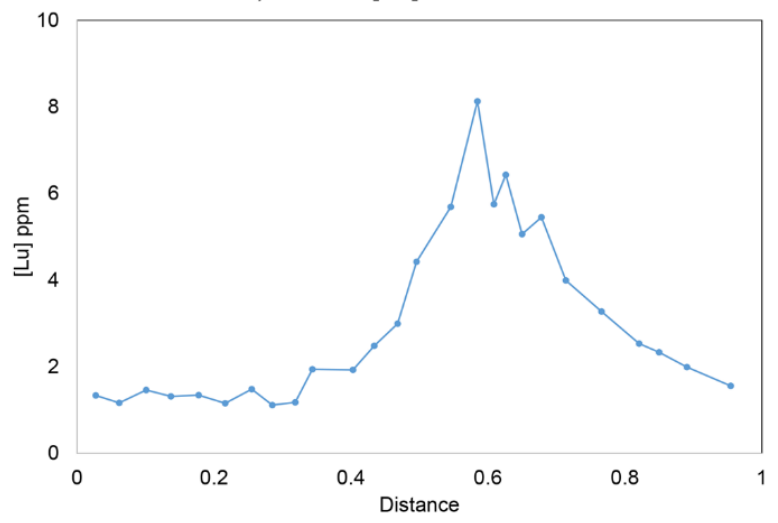

Figure 12: Garnet Lu zoning profiles. A) Lutetium concentration as a function of distance in sample AT021. B) Lutetium concentration as a function of distance in sample AT-076 C) Lutetium concentration as a function of distance in sample AT-068. D) Lutetium concentration as a function of distance in sample AT028. E) Lutetium concentration as a function of distance in sample AT-047. 


\section{Monazite U-Pb Geochronology}

In order to date the timing of deformation related to the Maz shear zone and interpret the cause of scatter in garnet Lu-Hf isochrons, monazite $\mathrm{U}-\mathrm{Th}-\mathrm{Pb}$ analysis was conducted on the sensitive high-resolution ion microprobe reverse-geometry (SHRIMP$R G$ ) ion microprobe co-operated by U.S. Geological Survey and Stanford University in the SUMAC facility at Stanford University. Analyses of monazite were performed in-situ on cut pieces of polished thin sections, which were trimmed with a diamond wire saw and embedded in epoxy. Secondary ions were sputtered from the target spot using an $\mathrm{O}^{2-}$ primary ion beam, which was accelerated at $10 \mathrm{kV}$ and had an intensity varying from 2.2 to $3.1 \mathrm{nA}$. The analytical sputter pit was $\sim 18 \times 20 \mu \mathrm{m}$ in diameter and a depth of $\sim 2-$ $3 \mu \mathrm{m}$. Monazite trace element $(\mathrm{Y}, \mathrm{REE}, \mathrm{U}, \mathrm{Th})$ concentrations were calculated relative to standard 44069 , which was calibrated based on the trace element concentration standard NAM monazite (Omarura, Namibia; Aleinikoff et al., 2012). Calculated model ages for monazite were standardized relative to standard $44069\left({ }^{206} \mathrm{~Pb} /{ }^{238} \mathrm{U}\right.$ age $=424$ Ma; Aleinikoff et al., 2006), which were analyzed repeatedly throughout the duration of the analytical session. Data reduction for geochronology follows the methods described by Ireland and Williams (2003) using the MS Excel add-in programs Squid 2.51 and Isoplot3.76 of Ken Ludwig (2009; 2012). The measured ${ }^{206} \mathrm{~Pb} /{ }^{238} \mathrm{U}$ was corrected for common $\mathrm{Pb}$ using ${ }^{207} \mathrm{~Pb}$, whereas ${ }^{207} \mathrm{~Pb} /{ }^{206} \mathrm{~Pb}$ was corrected using ${ }^{204} \mathrm{~Pb}$ and a model $\mathrm{Pb}$ composition from Stacey and Kramers (1975). No additional error was propagated for the uncertainty in the common $\mathrm{Pb}$ composition. All reported ${ }^{206} \mathrm{~Pb} / 238 \mathrm{U}$ and ${ }^{207} \mathrm{~Pb} /{ }^{206} \mathrm{~Pb}$ model ages and uncertainties $(2 \sigma)$ include error summed in quadrature from the external reproducibility $(1 \sigma \mathrm{SD})$ of the standard 44069 during an individual analytical 
session (24 hours). Concentrations and isotopic data for monazite $\mathrm{U}-\mathrm{Pb}$ analyses are listed in Table 5

\section{Maz Shear Zone}

Monazite in sample AT-076 from within the Maz shear zone occurs as elongate grains within the mylonitic foliation and no monazite was observed as inclusions within garnet. Back-scatter electron (BSE) imaging of monazite (Figure 13) shows patchy and somewhat irregular zoning of BSE-light and BSE-dark regions. Despite zoning irregularities, populations of monazite were indistinguishable based on rare earth element concentrations (Figure 14A). Fourteen analyses produced ${ }^{207} \mathrm{~Pb}$ corrected ${ }^{206} \mathrm{~Pb} / 238 \mathrm{U}$ ages ranging from $\sim 402$ to $\sim 428 \mathrm{Ma}$ with no significant age or trace element differences among regions of differing back-scatter intensity. The concordia age resulted in $421 \pm 4.2 \mathrm{Ma}(\mathrm{MSWD}=1.03)$ while the inverse concordia age gave $435 \pm 31$ Ma $(M S W D=4.0)$ with an overall weighted mean ${ }^{206} \mathrm{~Pb} / 238 \mathrm{U}$ age of $418.7 \pm 3.3 \mathrm{Ma}$ $(M S W D=1.14)($ Figure 14). The weighted mean age is interpreted to date growth of monazite within the foliation of the Maz shear after initial garnet growth and during deformation. 

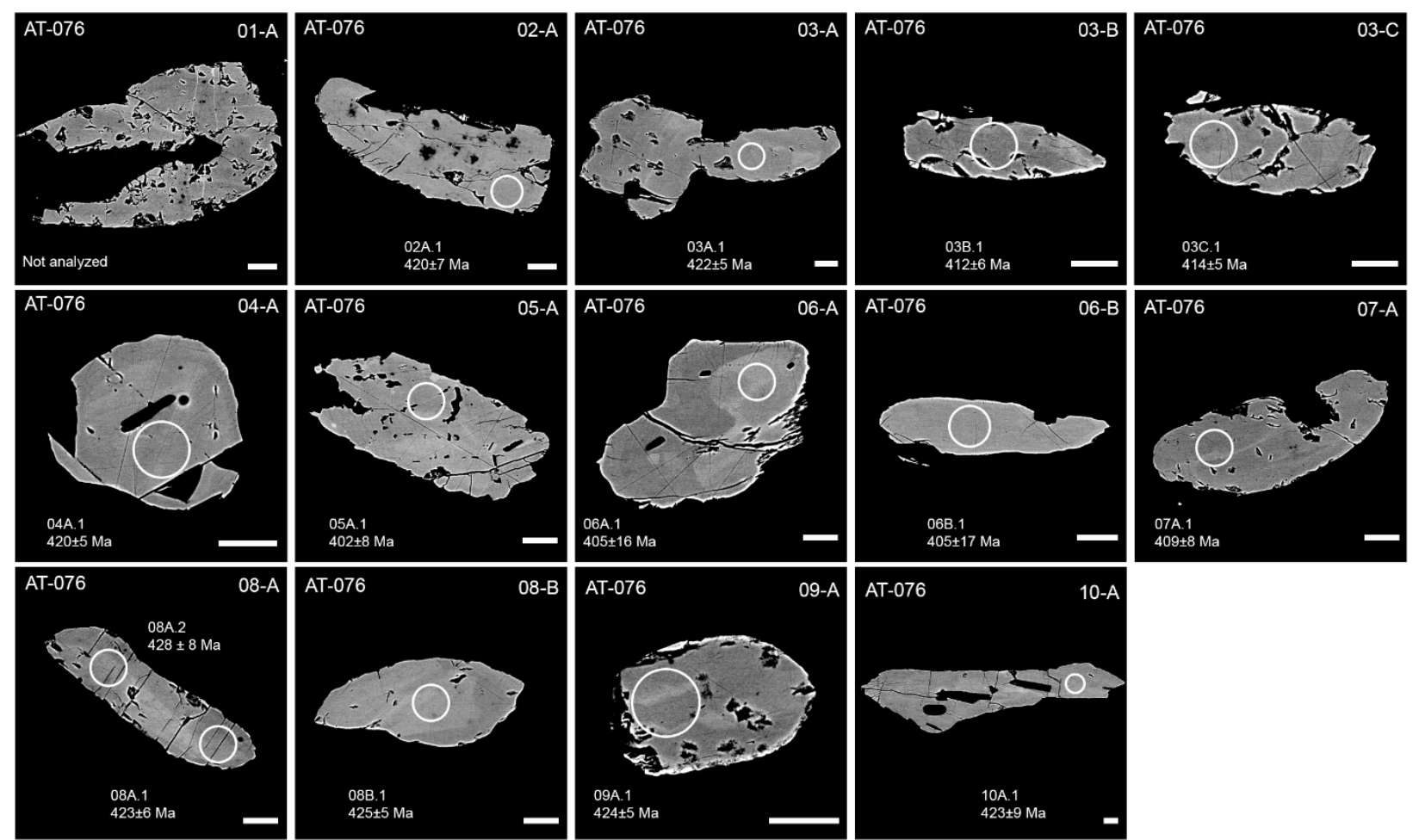

Figure 13: Back scatter electron images of analyzed monazite from sample AT-076 from the Maz shear zone. Circles outline $\sim 20$ um analytical spots. White bar at lower right corner is $10 \mathrm{um}$. 

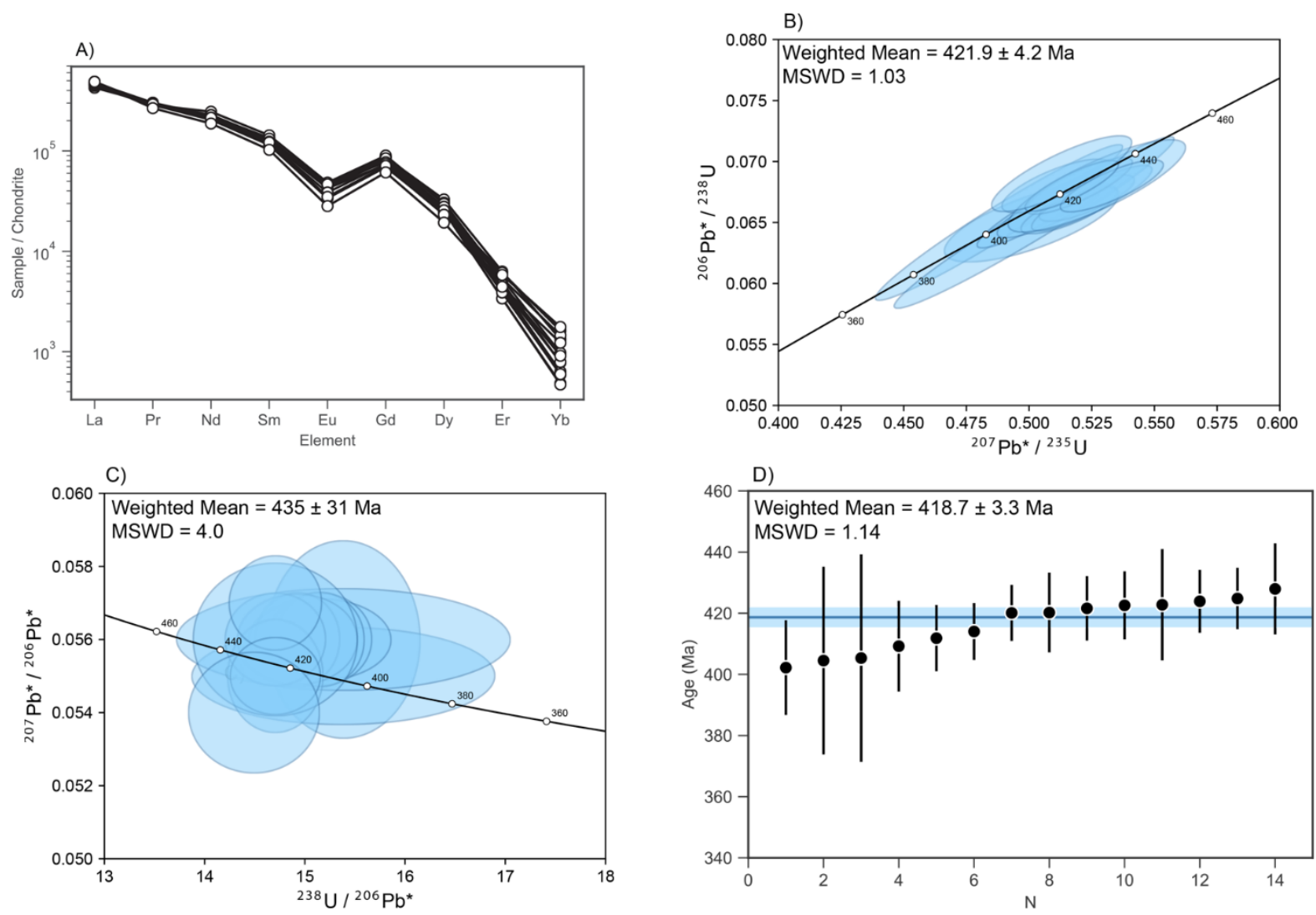

Figure 14: Monazite geochronology of sample AT-076 from the Maz shear zone. A) REE distributions of analyzed spots normalized to chondritic compositions. B) Concordia diagram with calculated age of $421 \pm$ 4.2 Ma (MSWD = 1.03). C) Inverse concordia diagram with fitted age of $435 \pm 31 \mathrm{Ma}(\mathrm{MSWD}=4.0)$. D) Analyzed ages showing $2 \sigma$ error bars and a weighted mean age of $418.7 \pm 3.3 \mathrm{Ma}(\mathrm{MSWD}=1.14$ ). Open circles represent ages excluded from the weighted mean calculation while closed circles indicate ages included in the weighted mean calculation. 


\section{Maz Complex}

Monazite from sample AT-068 of the Finca shear zone typically occurs as elongate grains within the mylonitic foliation and as inclusions in both garnet and staurolite. Back scatter electron imaging of monazites (Figure 15) reveal sector-zoned, and patchy regions of BSE-light and BSE-dark regions. Monazite are indistinguishable in rare-earth concentrations barring a single analysis from a monazite inclusion within an unfractured region in garnet. Twenty-two analyses of matrix monazite and monazite inclusions along fractures in garnet and staurolite produced ages ranging between $\sim 381$ and $\sim 428 \mathrm{Ma}$, with weighted mean ${ }^{206} \mathrm{~Pb} /{ }^{238} \mathrm{U}$ age of $410.6 \pm 2.4 \mathrm{Ma}(\mathrm{MSWD}=1.57)$ (Figure 16). A single grain of monazite in garnet not associated with fractures gave a ${ }^{204} \mathrm{~Pb}$ corrected ${ }^{207} \mathrm{~Pb} /{ }^{206} \mathrm{~Pb}$ age of $1149 \pm 12 \mathrm{Ma}$. A regression line plotted through matrix grains, inclusionary grains along fractures, and the discordant grain has an upper intercept of $1219 \pm 88 \mathrm{Ma}$ and a lower intercept of $404 \pm 20 \mathrm{Ma}$ (MSWD = 2.2). The upper intercept is interpreted to represent the date monazite growth during initial metamorphism. The weighted mean age of matrix monazite is interpreted to date of monazite growth during deformation in the Finca shear zone. 


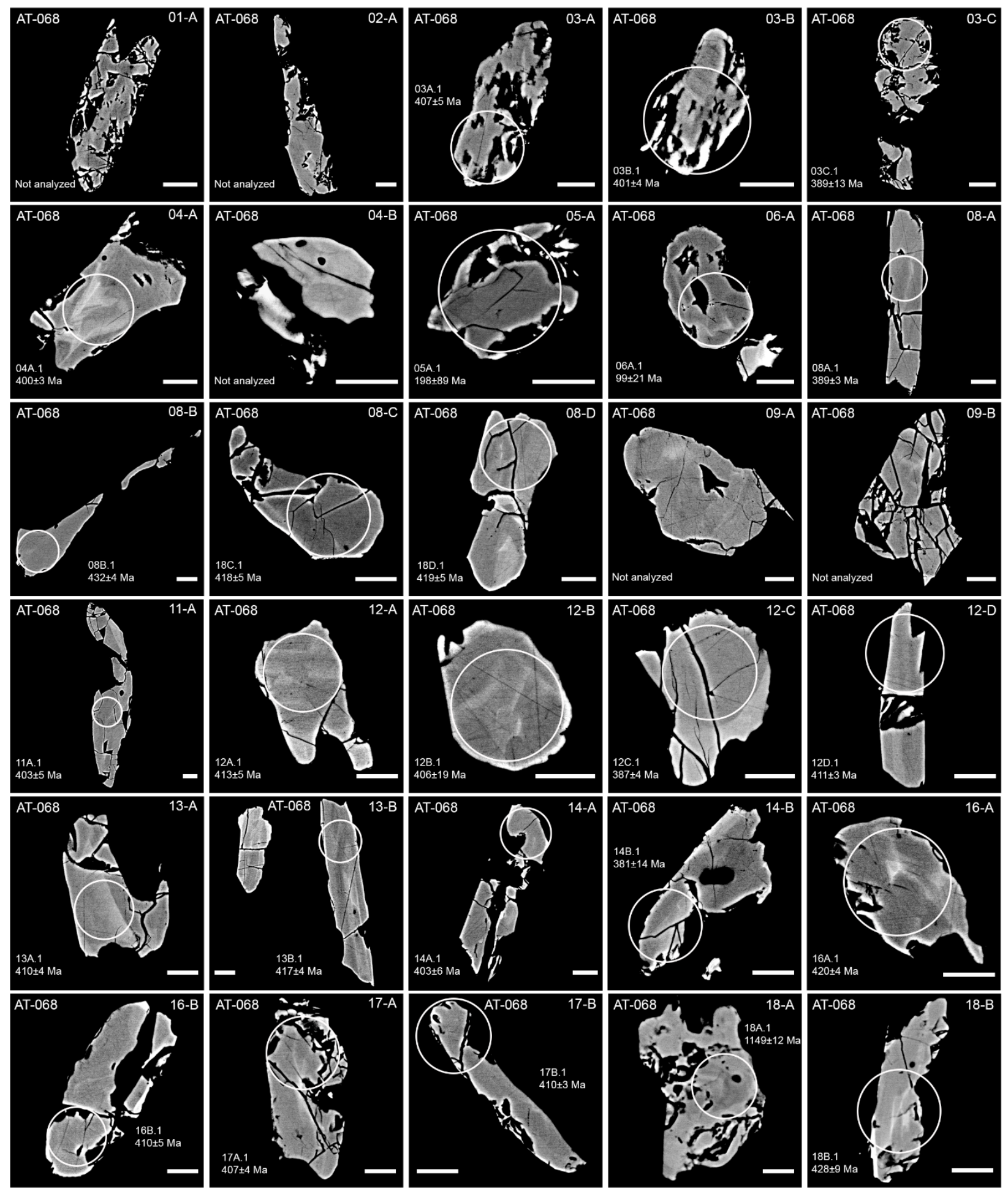

Figure 15: Back scatter electron images of analyzed monazite from sample AT-068 from the Finca shear zone. Circles outline $\sim 20$ um analytical spots. White bar at lower right corner is $10 \mathrm{um}$. 

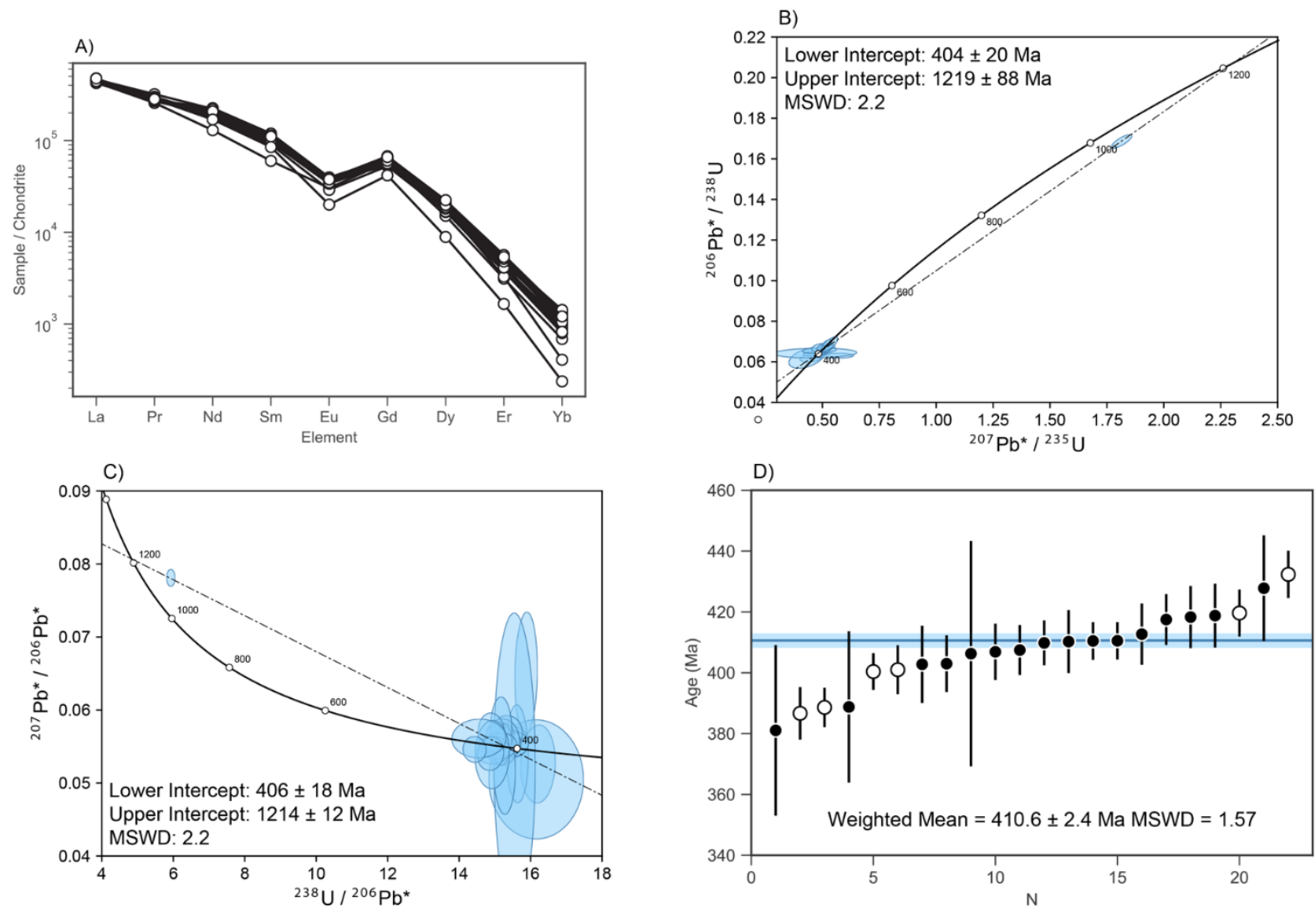

Figure 16: Monazite geochronology of sample AT-068 from the Finca shear zone. A) REE distributions of analyzed spots from sample AT-068 normalized to chondritic compositions. B) Concordia diagram with calculated upper intercept age of $1219 \pm 88 \mathrm{Ma}$ and lower intercept age of $404 \pm 20 \mathrm{Ma}$ (MSWD = 2.2). C) Inverse concordia diagram calculated upper intercept age of $1214 \pm 12 \mathrm{Ma}$ and lower intercept age of 406 $\pm 18 \mathrm{Ma}(\mathrm{MSWD}=2.2) \mathrm{D}$ ) Analyzed ages showing $2 \sigma$ error bars and a weighted mean age of $410.6 \pm 2.4$ $\mathrm{Ma}(\mathrm{MSWD}=1.57)$. Open circles represent ages excluded from the weighted mean calculation while closed circles indicate ages included in the weighted mean calculation.

Monazite from sample AT-028 occurs as elongate grains within the matrix of the foliation and as coarse inclusions in garnet up to 200 microns in length. Back-scatter electron imaging of monazite (Figure 17) show variable zoning patterns that can be broadly grouped into three main categories: 1) bright, oscillatory-zoned cores, 2) patchy overgrowths commonly forming around cores, 3) dark, unzoned asymmetrical rims on matrix grains. Two general populations can be identified through rare-earth element 
concentrations of distinctly different enrichments and a continuous range that lies between these two (Figure 18A). Twenty-five analyses from nineteen grains with zoned cores produced concordant ${ }^{204} \mathrm{~Pb}$ corrected ${ }^{207} \mathrm{~Pb} /{ }^{206} \mathrm{~Pb}$ ages that range from $\sim 1191$ to -1262 Ma. The concordia plot resulted in an upper intercept age of $1236 \pm 18 \mathrm{Ma}$ (MSWD = 1.8), while the inverse concordia plot gave an upper intercept of $1230 \pm 21$ Ma (NSWD = 1.8). The weighted mean age for this population is $1227.1 \pm 6.8 \mathrm{Ma}$ $(M S W D=1.55)($ Figure 18). Dark, homogenous rims on matrix grains resulted in concordant ${ }^{207} \mathrm{~Pb}$ corrected ${ }^{206} \mathrm{~Pb} /{ }^{238} \mathrm{U}$ ages ranging from $\sim 379$ to $\sim 424 \mathrm{Ma}$ The concordia plot has a lower intercept age of $415 \pm 33 \mathrm{Ma}(M S W D=1.8)$ while the inverse concordia plot has a lower intercept of $404 \pm 16 \mathrm{Ma}(\mathrm{MSWD}=1.8)$. The weighted mean age of this population is $413.2 \pm 5.0 \mathrm{Ma}(\mathrm{MSWD}=7.68)$ (Figure 18) with rim analyses exhibiting higher REE concentrations compared to core populations. Patchy recrystallized/overgrowth textures produced discordant ages that as young as $\sim 900 \mathrm{Ma}$. The resultant ages and corresponding textures suggest that at least two distinct populations of monazite exist within sample AT-028 (Figure 18). Oscillatory zoning is commonly observed in igneous monazite (Engi, 2017), and thus the weighted mean age of that texture could represent an igneous formation age. The weighted mean for younger, concordant rim ages are interpreted to represent growth of metamorphic monazite in the matrix during shear within the Sierra de Maz. 

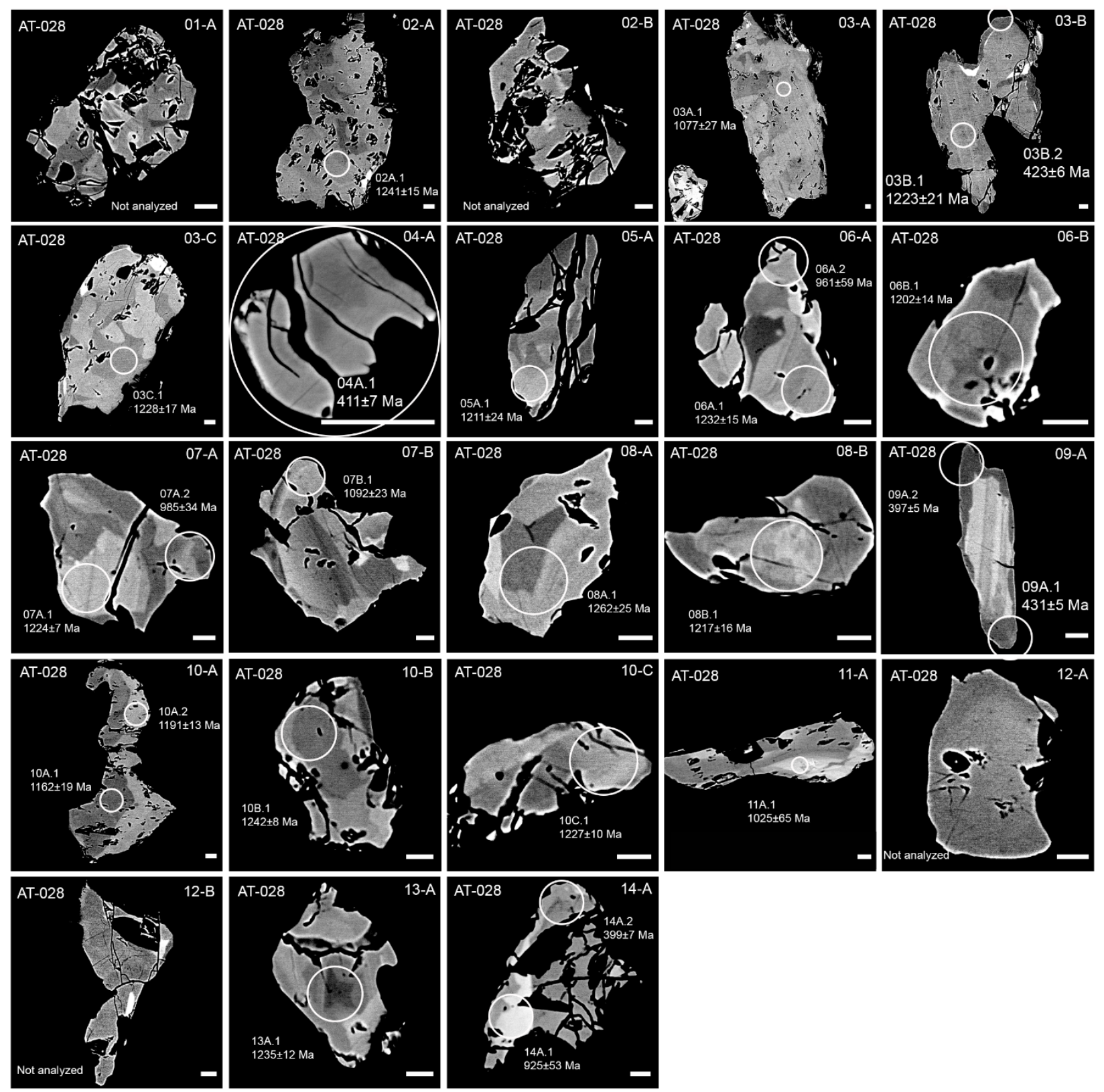

Figure 17: Back scatter electron images of analyzed monazite from sample AT-028 within the Maz Complex. Circles outline -20 um analytical spots. White bar at lower right corner is $10 \mathrm{um}$. 

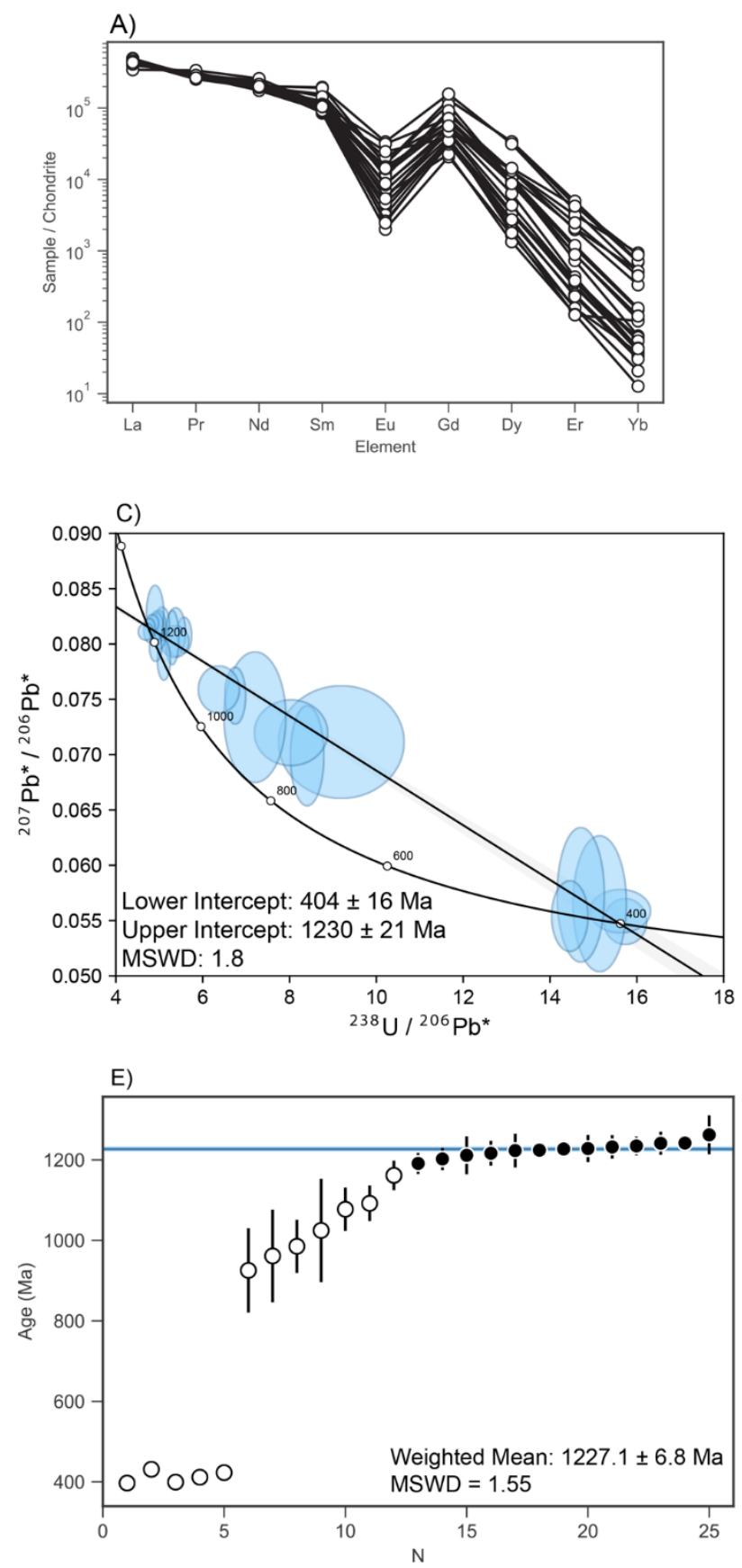
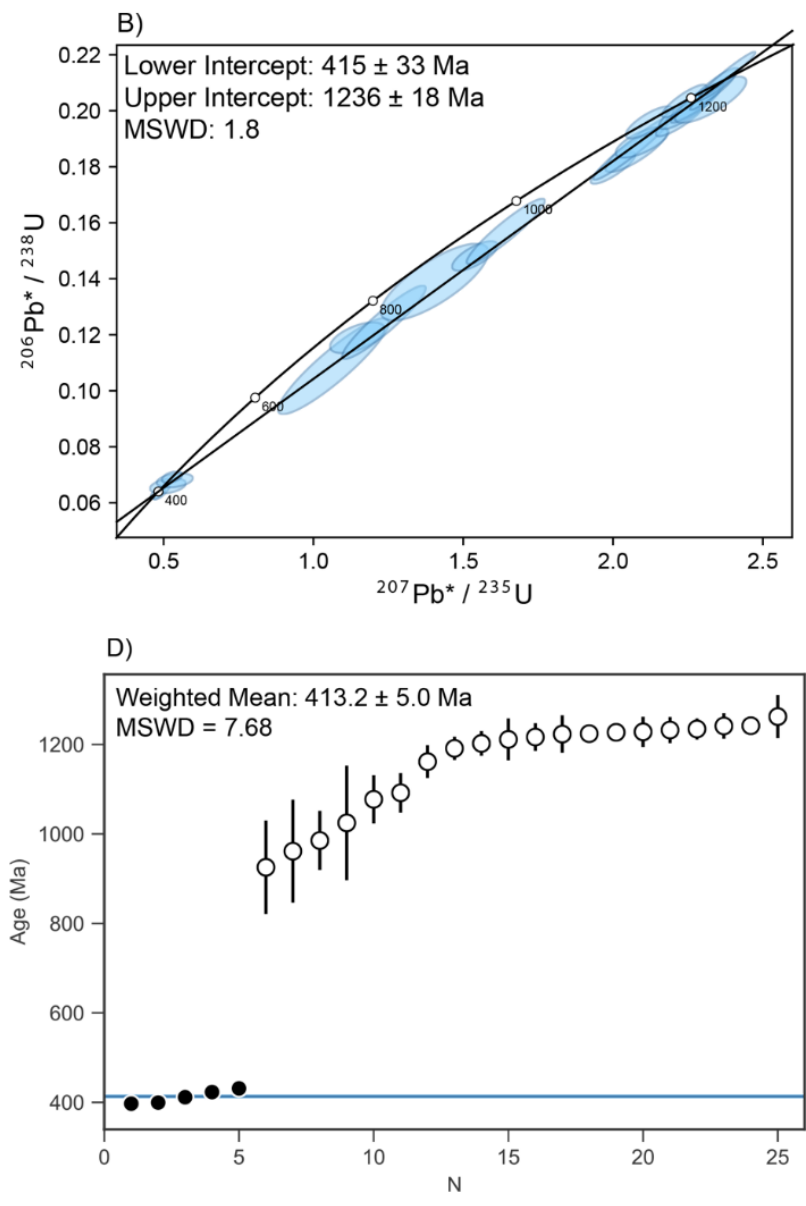

Figure 18: Monazite geochronology of sample AT-028 from the Maz Complex. A) REE distributions of analyzed spots from sample AT-028 normalized to chondritic compositions. B) Concordia diagram with calculated upper intercept age of $1236 \pm 18 \mathrm{Ma}$ and lower intercept age of $415 \pm 33 \mathrm{Ma}$ (MSWD = 1.8). C) Inverse concordia diagram calculated upper intercept age of $1230 \pm 21 \mathrm{Ma}$ and lower intercept age of 404 $\pm 16 \mathrm{Ma}(\mathrm{MSWD}=1.8) \mathrm{D}$ ) Analyzed ages showing $2 \sigma$ error bars and a distinct monazite population with a weighted mean age of $413.6 \pm 5.0 \mathrm{Ma}(\mathrm{MSWD}=7.68)$. E) Analyzed ages showing $2 \sigma$ error bars and a distinct monazite population with a weighted mean age of 1227.1 $\pm 6.8 \mathrm{Ma}(\mathrm{MSWD}=1.55)$. Open circles represent ages excluded from the weighted mean calculation while closed circles indicate ages included in the weighted mean calculation. 


\section{Ramaditas Complex}

Monazite from sample AT-047 of the Ramaditas Complex occurs as rounded to elongate grains within the matrix foliation and as anhedral inclusions in garnet. Monazite shows patchy and irregular zoning of BSE-light and BSE-dark regions (Figure 19). A general spread in the rare-earth element concentrations does not correlate with age. Fifteen grains produced concordant ages that range from $\sim 418$ and $\sim 472 \mathrm{Ma}$. The concordia age for this sample is $453.1 \pm 6.5 \mathrm{MA}(\mathrm{MSWD}=1.0)$ while the inverse concordia age is $453.2 \pm 6.4 \mathrm{Ma}(\mathrm{MSWD}=1.0)$ (Figure 20$)$. Texturally distinct monazite cores gave a ${ }^{207} \mathrm{~Pb}$ corrected ${ }^{206} \mathrm{~Pb} /{ }^{238} \mathrm{U}$ weighted mean of $461.6 \pm 3.1 \mathrm{Ma}(\mathrm{MSWD}=$ 1.6) and the monazite rims gave a ${ }^{207} \mathrm{~Pb}$ corrected ${ }^{206} \mathrm{~Pb} /{ }^{238} \mathrm{U}$ weighted mean of 426.1 $\pm 7.0 \mathrm{Ma}(\mathrm{MSWD}=1.02)$ (Figure 20). The weighted mean age of the older population is interpreted to represent growth of metamorphic monazite during peak granulite facies. The weighted mean age of the younger population could be interpreted as metamorphism and deformation associated with the Ramaditas shear zone.

\section{Summary}

Monazite ages from three samples within the Sierra de Maz suggests that the deformation related to the Maz shear zone resulted in monazite growth across the range at $\sim 415 \mathrm{Ma}$. The majority of monazite ages from within the Sierra de Ramaditas do not overlap within uncertainty of monazite ages found within the Sierra de Maz. Proterozoic monazite was analyzed in two samples from within the Sierra de Maz and are absent from rocks of the Sierra de Ramaditas. A summary table of all ages presented in this study can be found in Table 6 . 

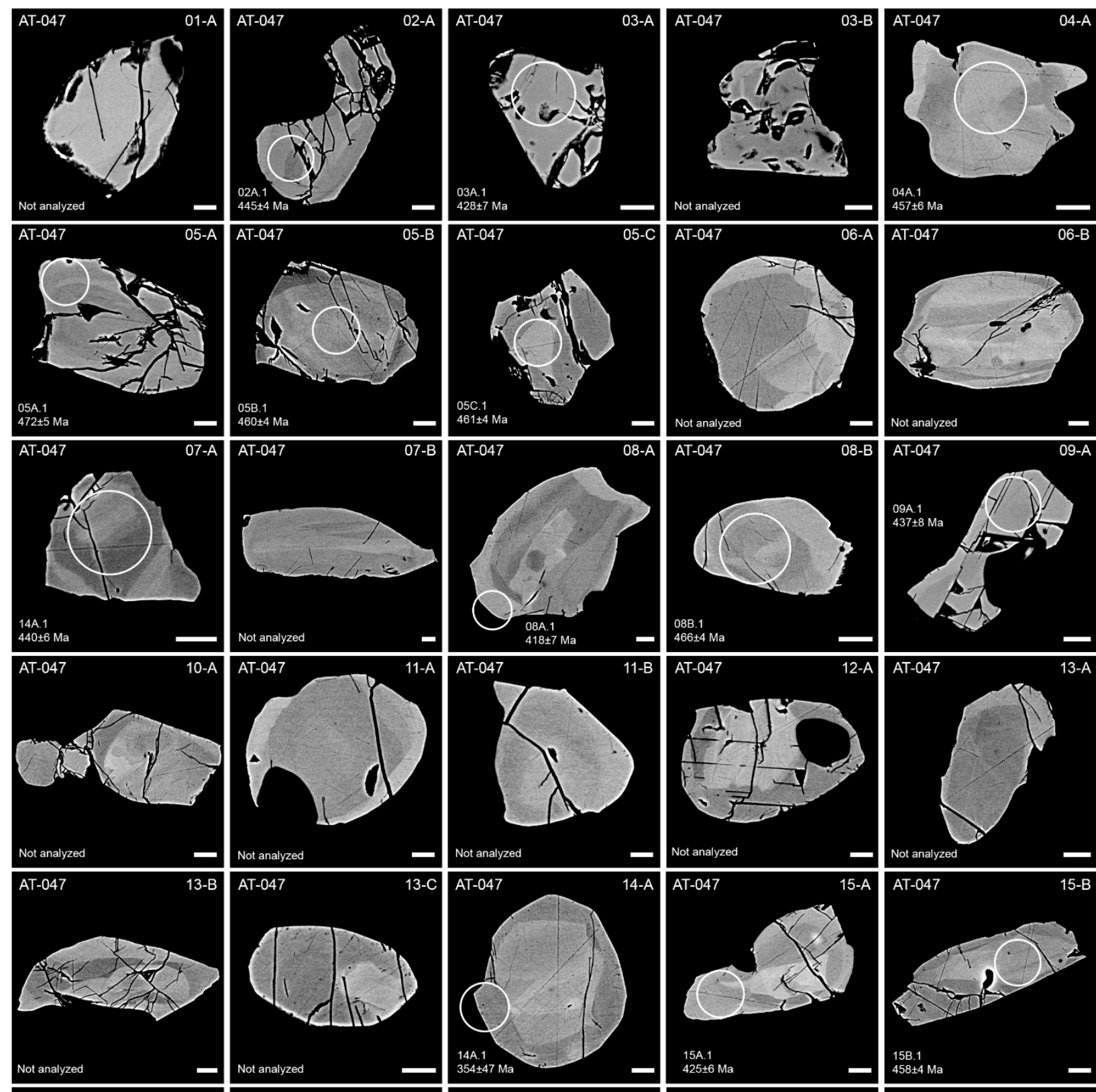

AT-047

(1)
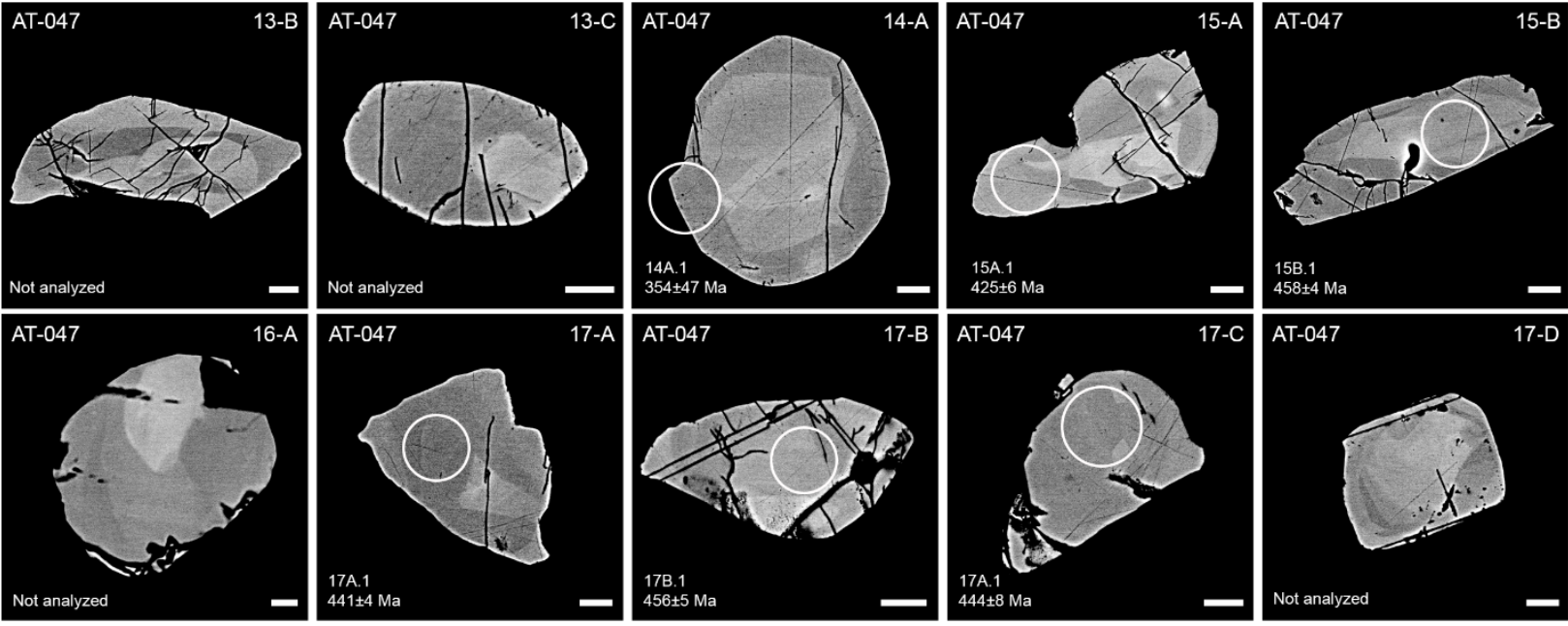

Figure 19: Back scatter electron images of analyzed monazite from sample AT-047 with white circles outlining $\sim 20$ um diameter analysis spot. White bar at lower right corner is $10 \mathrm{um}$. 

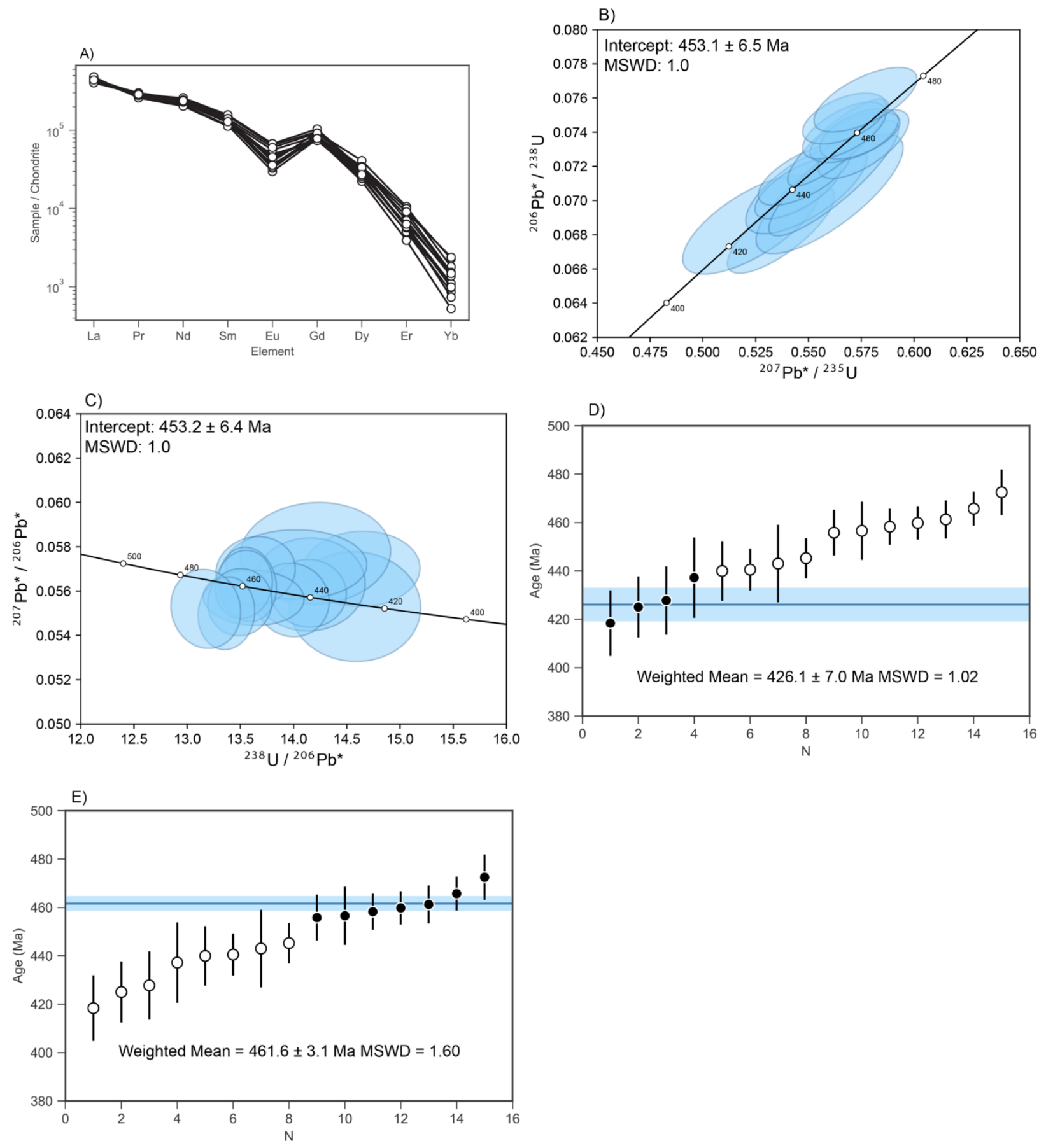

Figure 20: A) REE distributions of analyzed spots from sample AT-047 normalized to chondritic compositions. B) Concordia diagram with calculated age of $453.1 \pm 6.5 \mathrm{Ma}$ (MSWD = 1.0). C) Inverse concordia diagram with fitted age of $453 \pm 6.4 \mathrm{Ma}(\mathrm{MSWD}=1.0)$. D) Analyzed ages showing $2 \sigma$ error bars and a monazite population with a weighted mean age of $426.1 \pm 7.0 \mathrm{Ma}$ (MSWD =1.02). E)

Analyzed ages showing $2 \sigma$ error bars and a monazite population with a weighted mean age of $461.1 \pm$ $3.1 \mathrm{Ma}(\mathrm{MSWD}=1.60)$. Open circles represent ages excluded from the weighted mean calculation while closed circles indicate ages included in the weighted mean calculation. 


\section{Discussion}

Data from this study stand in contrast to the geotectonic model for the MARA terrane proposed by Rapela et al. (2016). Direct evidence of a Cambrian orthogonal collision and $\sim 525$ Ma partial subduction is still lacking within units of northern Sierra de Maz. Metamorphic ages presented in this study add to the growing dataset of ages that are not explained by the Rapela (2016) model. Silurian titanite ages within the Sierra de Maz were reported by Luccassen and Becchio (2003) and by Casquet et al. (2006), but were not related to a metamorphic event or deformation fabric. This study dates Silurian-Devonian deformation and metamorphism within the Sierra de Maz and allows for direct comparisons to be made between the various ranges of the southern MARA terrane.

Peak metamorphic conditions of Zaino, Maz, and Ramaditas metapelites are distinctly different according to observed assemblages, P-T approximations, and garnet zoning profiles. The Zaino Complex contains the lowest metamorphic grades in the Sierra de Maz with the dominant assemblage of Grt-Bt-Ms-Plg-Qtz (Figure 7C) and rare staurolite-bearing metapelites in the most eastern outcrops (Figure 7D). Pressure and temperature estimates from this unit range within uncertainty of the amphibolite to upper amphibolite facies and reflect the west to east increase in metamorphic grade suggested by pelitic index minerals (Figure 4). Post kinematic, prograde growth-zoned garnet (Figure 8A and Figure 9A) within Zaino peak assemblages suggest a single phase of metamorphism. Conversely, metapelites from the Maz Complex show evidence for multiple metamorphic events at higher temperatures and pressures than the Zaino Complex. A west to east increase in metamorphic grade within the Maz 
Complex is apparent in pelitic index minerals, with temperatures and pressure estimates starting in the upper amphibolite facies with the assemblage Grt-St-Ms-Plg-Bt \pm Ky and ending in the granulite facies with the assemblage Grt-Bt-Plg-Kfs-Sil. The presence of pre-kinematic garnets (Figure 7G) and complicated zoning profiles from samples AT068 (Figure 8C) and AT-028 (Figure 9D) indicate the unit experienced more than one metamorphic event. Kyanite inclusions in garnet from an eastern granulite sample AT028 (Figure 7I) that contains sillimanite in the matrix implies that granulite conditions were attained during the most recent foliation-forming event. Metapelites from the Ramaditas Complex bear evidence for the lowest metamorphic pressures of the three studied units. The assemblage Cd-Grt-Bt-Plg-Qtz qualitatively suggests that peak metamorphic conditions were at least 2 kbars lower than the adjacent eastern units of the Maz Complex. Pressure and temperature calculations from Ramaditas sample AT047 confirm that metamorphic pressures do not overlap within uncertainty with any other analysis within the Sierra de Maz (Figure 7). Furthermore, garnet from the Sierra de Ramaditas are diffusively zoned (Figure 9E) indicating a single event of slow cooling from high-T conditions, unlike garnet from the Sierra de Maz. 


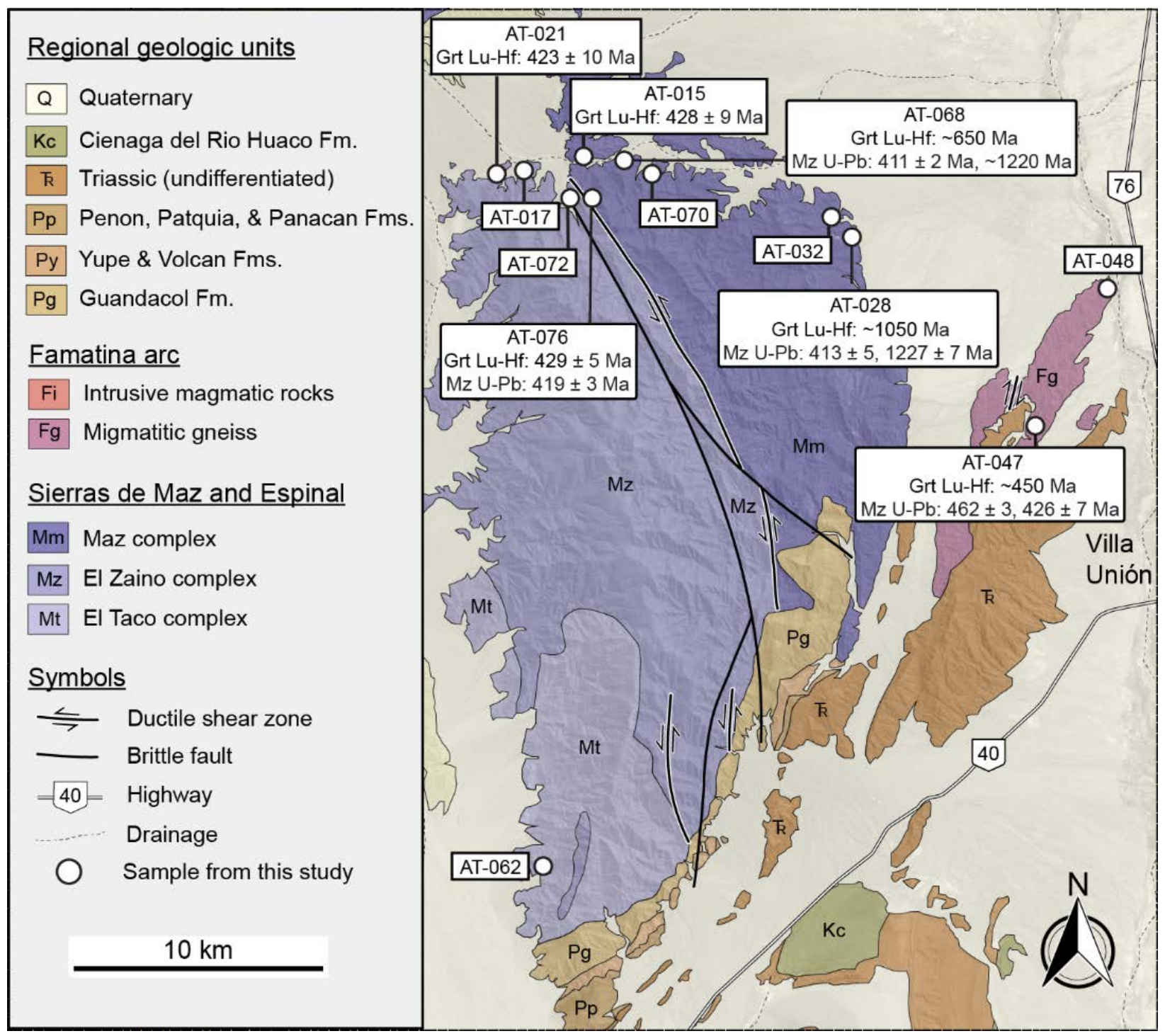

Figure 21: Geologic map of the Sierra de Maz with the locations and ages of samples dated in this study. 
The distribution of metamorphic ages is variable among the Zaino, Maz, and Ramaditas Complexes. Of the three, the Zaino Complex has the simplest history with a single age of peak metamorphism inferred from the garnet Lu-Hf age of $423 \pm 10 \mathrm{Ma}$ $(M S W D=4.6)$ from sample AT-021 (Figure 21). This garnet crystallization event overlaps within uncertainty of two additional garnet Lu-Hf ages from within the Maz shear zone of $429 \pm 5 \mathrm{Ma}(\mathrm{MSWD}=2.6)$ and $428 \pm 9 \mathrm{Ma}(\mathrm{MSWD}=5.6)$. When taken together, three similar ages of garnet growth are interpreted to record burial and metamorphism of the Zaino complex during oblique thrusting along the Maz shear zone.

The Maz Complex contains an older history of metamorphism not found within the Zaino Complex. Proterozoic garnet growth is inferred from the scattered isochron plot of sample AT-028 (Figure 11E). This older history is also evident in a U-Pb weighted mean age of $1227.1 \pm 6.8 \mathrm{Ma}$ from monazite inclusions within garnets of the Maz Complex and overlaps with U-Pb ages from metamorphic overgrowths on detrital zircons first identified by Casquet et al. (2006). The event recorded by these two phases places rough constraints on metamorphism of rocks comprising the Maz Complex. The Maz Complex subsequently experienced thermal events from $\sim 1.0 \mathrm{Ga}$ anorthosite intrusions, at $\sim 845 \mathrm{Ma}$ and $\sim 774 \mathrm{Ma}$ by granitoid intrusions, and at $\sim 570 \mathrm{Ma}$ from carbonatite intrusions, all of which are currently absent from the Zaino and Ramaditas Complexes (Casquet et al., 2008a; Casquet et al., 2008b; Colombo et al., 2009; Rapela et al., 2010).

Ordovician metamorphic ages from the Ramaditas Complex are unique within the study area. Garnet Lu-Hf isochrons from sample AT-047 resulted in an older threepoint isochron age of $461 \pm 1.7 \mathrm{Ma}$ and a younger three-point isochron of $449 \pm 1.6 \mathrm{Ma}$. 
While the validity of three-point isochrons may be suspect, when all analyses are taken together, the age of garnet growth for this region appears to be at least 30 my older than shear related metamorphism in the Sierra de Maz. Ordovician signatures are also evident in the U-Pb ages of matrix monazite from sample AT-047 with concordia and Terra-Wasserburg calculated ages of $453.1 \pm 6.5 \mathrm{Ma}(\mathrm{MSWD}=1.0)($ Figure 20B $)$ and 453.2 \pm 6.4 Ma (MSWD = 1.0) (Figure 20C) respectively. Despite the multitude of thermal events experienced by the Maz Complex, Ramaditas is unique in its dominantly Ordovician signature despite the presence of Silurian monazite. Ordovician metamorphic ages, diffusively zoned garnets, and low pressure pelitic assemblages imply the Ramaditas Complex most likely recorded contact metamorphism related to Famatina arc magmatism.

Silurian - Devonian metamorphism observed within all of the units in the Sierra de Maz was a result of transpressive deformation along the Maz shear zone. Similar garnet and monazite ages in the Zaino Complex, Maz shear zone, Finca shear zone, and Maz Complex imply the inverted metamorphic gradient formed during deformation associated with Maz shear zone. These age interpretations are supported by fieldbased evidence of similar foliation orientations and sinistral-reverse kinematics. Thus, it can be assumed that the west to east inverted metamorphic sequence is direct result of transpression. Thermal modeling conducted by Thompson et al. (1997) demonstrated that low angles $\left(\leq 30^{\circ}\right)$ of oblique convergence (low ratios of pure/simple shear) can cause Barrovian to granulite conditions in transpressive orogens with long-lived periods of high temperatures. Shallow lineations and steeply dipping foliations across the Sierra de Maz indicate that the angle of obliquity was, on average, less than $30^{\circ}$ within the 
Maz shear zone (Figure 4) and within the geometric bounds proposed by Thompson et al., (1997). An unpublished Ar-Ar white mica cooling age of $\sim 386.5 \pm 1.0 \mathrm{Ma}$ (E. Houlihan, written communication, 2018) from directly within the Maz shear zone implies temperatures stayed above mica closure for at least 50 my following garnet growth, consistent with the long-lived transpressive thermal regimes predicted by Thompson et al. (1997). The extrusional dynamics presented by Thompson et al. (1997) could explain a nominally younger age of $410.6 \pm 2.4$ Ma from sample AT-068 suggesting that this area could have acted as a weak zone accommodating later shortening.

Similar metamorphic PT trends as a function of structural distance (Figure 22) have been observed in other transpressive orogens such as Kaoko Belt in Namibia and the Kalinjala Shear Zone in South Australia (Goscombe and Gray, 2009), but are slightly different than what is seen in the Sierra de Maz. In the Namibian orogen, granulite conditions are seen to exist within the orogen-scale median shear zone and diminish away from the shear zone in both directions. Within the northern Sierra de Maz, metamorphic conditions between major blocks (Maz shear zone) are calculated to have reached upper amphibolite facies with granulite conditions several kilometers east. This difference could be a preservation problem, with the true orogen median shear zone being just east of the Sierra de Maz, lost to erosion or possibly buried under sediments. 

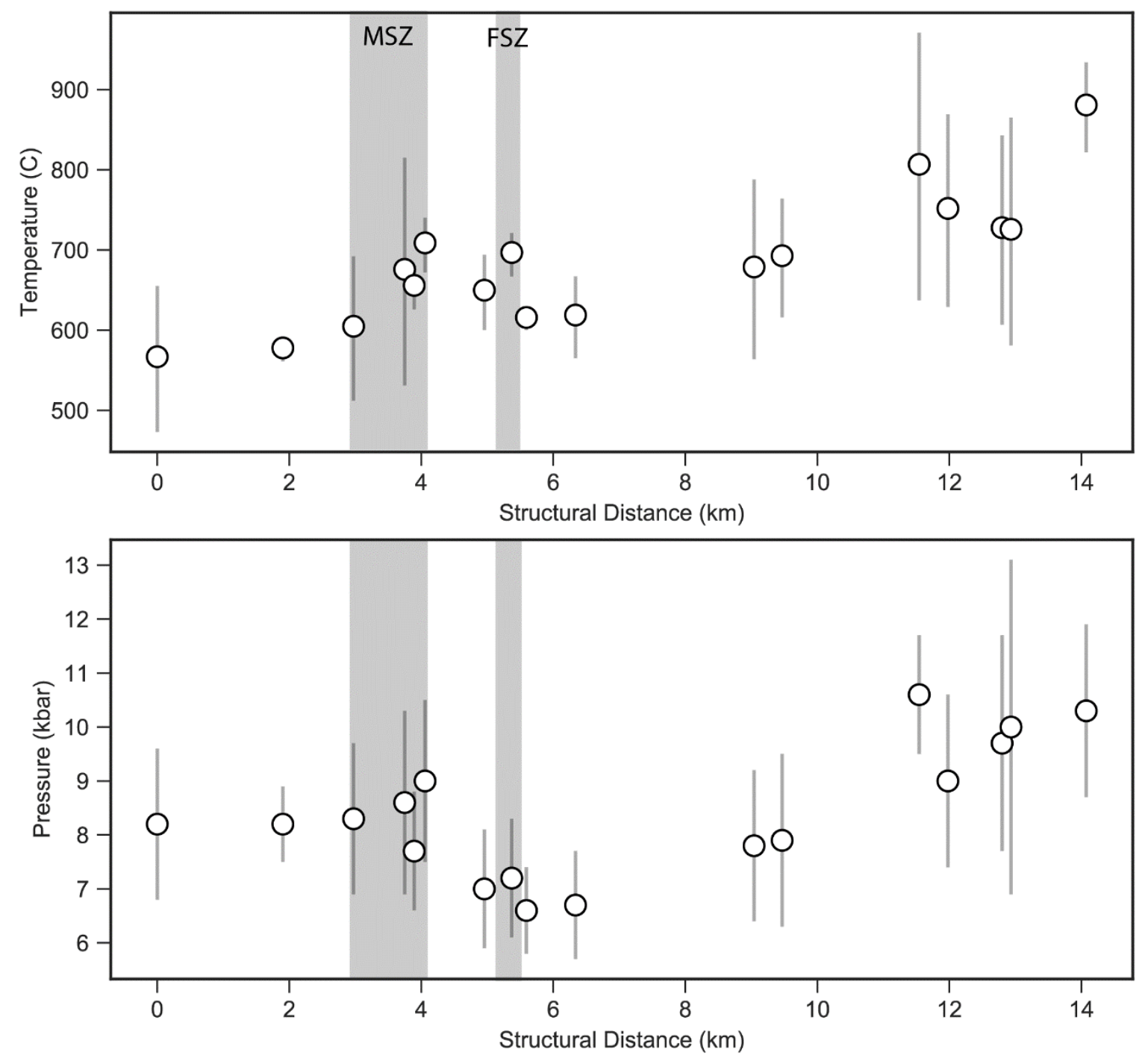

Figure 22: Temperature and pressure across the Sierra de Maz (MSZ = Maz shear zone; FSZ = Finca shear zone). 
Metamorphic ages from the Zaino and Maz Complexes do not support correlations with other proposed MARA units in the region (Figure 1). The Taco Complex in the southwest Sierra de Maz (Figure 3) contains unpublished metamorphic ages spanning 470 - $440 \mathrm{Ma}$ (P. Webber, written communication, 2018). To the northwest within the Sierra de Umango, $\sim 452$ Ma monazite, $\sim 446$ Ma metamorphic zircon overgrowths (Varela et al., 2010) and $\sim 440$ Ma titanite (Luccasen \& Becchio, 2003) are different from ages found within the Zaino and Maz Complexes. To the south, exposures in the Sierra de Pie de Palo (Figure 1) record oblique thrusting along low-angle shear zones between $\sim 515 \mathrm{Ma}$ and $\sim 440 \mathrm{Ma}$ (Mulcahy et al., 2011). The age data require that the Zaino and Maz Complexes of the Sierra de Maz do not share the same metamorphic histories preserved in the Sierra de Pie de Palo, the Sierra de Umango, or the Taco Complex. Continued work uncovering metamorphic cooling ages within the Taco Complex, the Sierra de Umango, and the Pie de Palo could provide the means to strengthen correlations between these ranges.

Considering the variable histories within the southern ranges of the MARA terrane that are unaccounted for in the Rapela et al. (2016) model, an additional model that accounts for Devonian-Silurian transpression must be proposed. Given the current distribution of ages, it must be assumed that that the Sierra de Maz was at one time spatially isolated from its present-day neighboring ranges. The southern ranges of the MARA terrane could represent composite terranes, with site-specific accretion and translation histories that span from the Cambrian through the Late Devonian. On the basis of shared metamorphic ages, this study speculates that the Taco Complex, the Sierra de Umango, and the Sierra de Pie de Palo were more or less amalgamated 
during the Ordovician. The absence of Ordovician Famatina ages within the Sierra de Maz suggests that these rocks were far enough away or at an isolated structural level to avoid significant arc interactions. Margin-scale transpression during the Silurian juxtaposed the Zaino Complex against the Maz Complex and deformed the contact aureole (Ramaditas Complex) of the Famatina arc. Transpression continued and translated the Sierra de Maz into its current position between ranges that experienced an Ordovician Famatinian history (Figure 23). Although the contact between the Zaino and Taco Complexes was not directly observed in this study, this model predicts a low angle thrust fault that is younger than the Silurian - Late Devonian deformation in the Zaino Complex. Additionally, this model predicts right-lateral faulting within the Sierra de Umango which is, at first order, supported by Meira et al. (2012) who documented right-lateral reverse-transpression with the Sierra de Umagno in the Ordovician and Silurian.

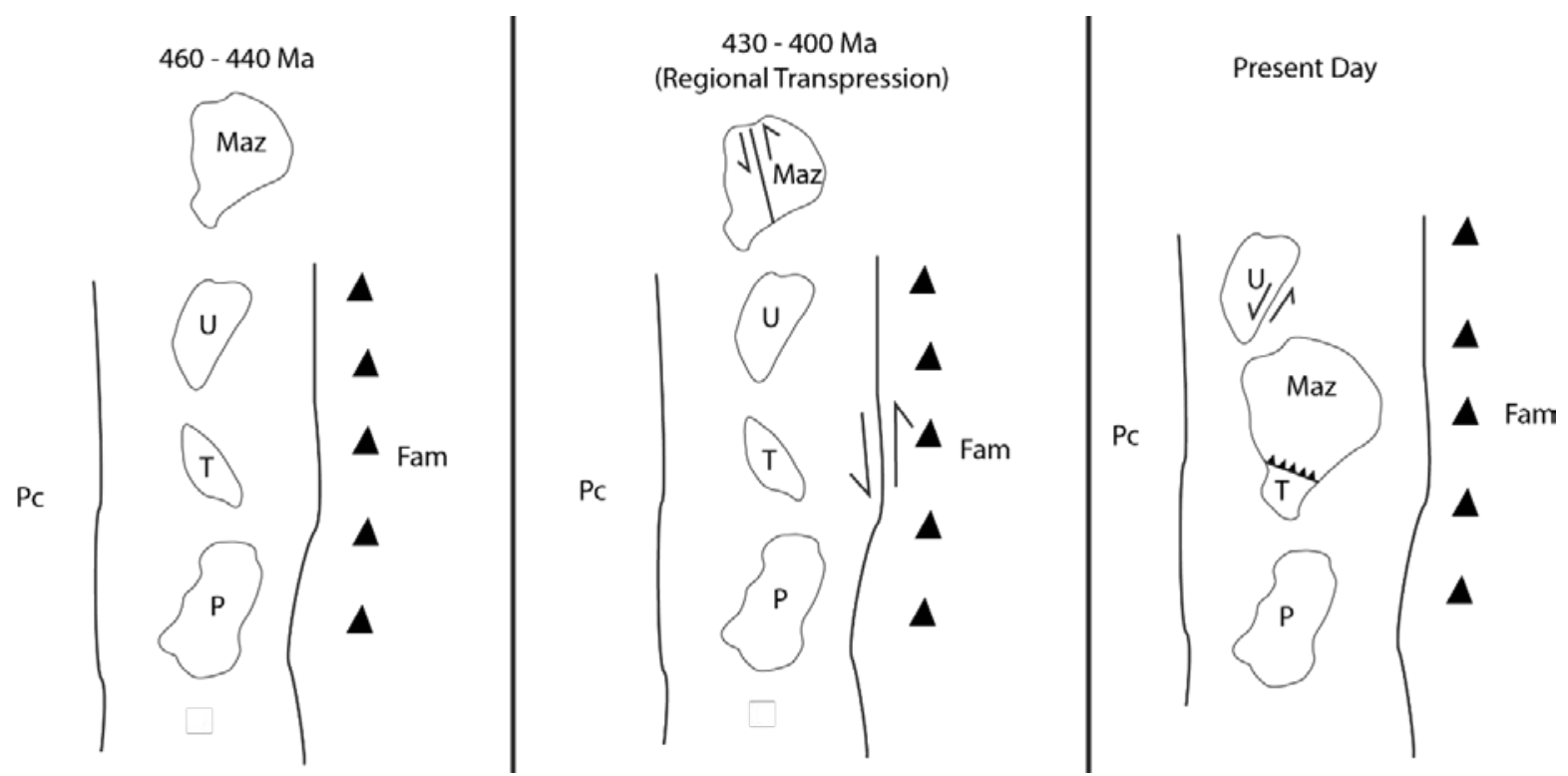

Figure 23: Map-view graphic of southern ranges of the MARA terrane depicting a simplified model for traspressiopnal deformation and displacement of the Sierra de Maz (Pc = Precorderilla, Fam = Famatina arc, $\mathrm{P}=$ Pie de Palo, $\mathrm{T}=$ Taco Complex, $\mathrm{U}=$ Sierra de Umango). 


\section{Conclusions}

Metapelitic rocks from the Sierra de Maz contain evidence for regional transpression throughout the Silurian and Early Devonian. Metamorphic crystallization related to this event bears no Ordovician Famatinian age signature, is apparent in fabrics across the entire range, and overprints older events that are preserved in relict metapelitic assemblages of the Maz Complex. Garnet and a majority of monazite growth in the Sierra de Ramaditas are coeval with Famatinian arc magmatism and exhibit peak metamorphic conditions at distinctly lower pressures when compared to the Sierra de Maz. Data from this study imply that Silurian-Devonian sinistral transpression was a major accretion process that shaped the MARA terrane and that continued deformation juxtaposed the Sierra de Maz adjacent to rocks recording Famatinian histories. 


\section{Works Cited}

Aleinikoff, J.N., Schenck, W.S., Plank, M.O., Srogi, L., Fanning, C.M., Kamo, S.L., and Bosbyshell, H., 2006. Deciphering igneous and metamorphic events in highgrade rocks of the Wilmington Complex, Delaware: Morphology, cathodoluminescence and backscattered electron zoning, and SHRIMP U-Pb geochronology of zircon and monazite. Geological Society of America Bulletin, v. 118 , p. 39-64.

Aleinikoff, J.N., Grauch, R.I., Mazdab, F.K., Kwak, L., Fanning, C.M., and Kamo, S.L., 2012. Origin of an unusual monazite-xenotime gneiss, Hudson Highlands, New York: SHRIMP U-Pb geochronology and trace element geochemistry. American Journal of Science, v. 312, p. 723-765.

Astini, R.A., Benedetto, J.L., and Vaccari, N.E., 1995, The early Paleozoic evolution of the Argentine Precordillera as a Laurentian rifted, drifted, and collided terrane: A geodynamic model: Geological Society of America Bulletin, v. 107, p. 253-273.

Brown, E.H., and Talbot, J.L., 1989, Orogen-parallel extension in the North Cascades Crystalline Core, Washington: Tectonics, v. 8, no. 6, p. 1105-1114, doi: 10.1029/tc008i006p01105.

Casquet, C., Pankhurst, R., Fanning, C.M., Baldo, E., Galindo, C., Rapela, C.W., González-Casado, J.M., and Dahlquist, J.A., 2006, U-Pb SHRIMP zircon dating of Grenvillian metamorphism in Western Sierras Pampeanas (Argentina) : correlation with the Arequipa-Antofalla craton and constraints on the extent of the Precordillera Terrane: Gondwana Research, v. 9, p. 524-529.

Casquet, C., Pankhurst, R., Galindo, C., Rapela, C.R., Fanning, C.M., Baldo, E., Dahlquist, J., Casado, J.M.G., and Colombo, F., 2008, A deformed alkaline igneous rock-carbonatite complex from the Western Sierras Pampeanas, Argentina : evidence for Late Neoproterozoic opening of the Clymene Ocean? Precambrian Research, v. 165, p. 205-220.

Casquet, C., Pankhurst, R.J., Rapela, C.W., Galindo, C., Fanning, C.M., Chiaradia, M., Baldo, E., González-Casado, J.M., and Dahlquist, J.A., 2008, The Mesoproterozoic Maz terrane in the Western Sierras Pampeanas, Argentina, equivalent to the Arequipa-Antofalla block of southern Peru? Implications for West Gondwana margin evolution: Gondwana Research, v. 13, p. 163-175.

Colombo, F., Baldo, E.G.A., Casquet, C., Pankhurst, R.J., Galindo, C., Rapela, C.W., Dahlquist, J.A., and Fanning, C.M., 2009, A-type magmatism in the sierras of 
Maz and Espinal: A new record of Rodinia break-up in the Western Sierras Pampeanas of Argentina: Precambrian Research, v. 175, p. 77-86.

Davis, J.S., Roeske, S.M., Mcclelland, W.C., and Snee, L.W., 1999, Closing the ocean between the Precordillera terrane and Chilenia: Early Devonian ophiolite emplacement and deformation in the southwest Precordillera: Special Paper 336: Laurentia-Gondwana connections before Pangea, p. 115-138, doi: 10.1130/08137-2336-1.115.

Davis, J.S., Roeske, S.M., Mcclelland, W.C., and Kay, S.M., 2000, Mafic and ultramafic crustal fragments of the southwestern Precordillera terrane and their bearing on tectonic models of the early Paleozoic in western Argentina: Geology, v. 28, no. 2, p. 171-174, doi: 10.1130/0091-7613(2000)028<0171: maucfo>2.3.co; 2.

Engi, M., 2017, 12. Petrochronology Based on REE-Minerals: Monazite, Allanite, Xenotime, Apatite: Petrochronology, doi: 10.1515/9783110561890-013.

Goscombe, B.D., and Gray, D.R., 2009, Metamorphic response in orogens of different obliquity, scale and geometry: Gondwana Research, v. 15, no. 2, p. 151-167, doi: 10.1016/j.gr.2008.07.005.

Gosen, W.V., Loske, W., and Prozzi, C., 2002, New isotopic dating of intrusive rocks in the Sierra de San Luis (Argentina): implications for the geodynamic history of the Eastern Sierras Pampeanas: Journal of South American Earth Sciences, v. 15, no. 2, p. 237-250, doi: 10.1016/s0895-9811(02)00016-0.

Houlihan, E., Tholt, A., Webber, P., Roeske, S.M., Mulcahy, S.R., Mcclelland, W.C., and Rutte, D., 2017, 40Ar/39Ar Geochronology And Kinematic Analysis Of Sierra De Maz: Implications For Timing And Orientation Of Deformation On The Paleozoic Margin Of Western Gondwana, GSA Annual Meeting, Seattle, Washington, Abstracts, Vol. 49, No.6.

Ireland, T.R., Ion Microscopes and Microprobes, Treatise on Geochemistry (2nd Edition), v. 15, p. 385-409.

Ireland, T.R., and Williams, I.S., 2003, considerations in zircon geochronology by SIMS, Reviews in Mineralogy and Geochemistry, v. 53, p. 215-241, Hanchar, J.M. and Hoskin, W.O., editors.

Jochum, K. P., Weis, U., Stoll, B., Kuzmin, D., Yang, Q., Raczek, I., Jacob, D. E., Stracke, A., Birbaum, K., Frick, D. A., Günther, D. and Enzweiler, J. (2011), Determination of Reference Values for NIST SRM 610-617 Glasses Following ISO Guidelines. Geostandards and Geoanalytical Research, 35: 397-429. 
Kilmurray, J.O., and Dalla Salda, L., 1971, Las fases de deformación y metamorfismo en la sierra de Maz, provincia de La Rioja, República Argentina: Revista de la Asociación Geológica Argentina, v. 26, p. 245-263.

Lucassen, F., and Becchio, R., 2003, Timing of high-grade metamorphism: Early Palaeozoic $\mathrm{U}-\mathrm{Pb}$ formation ages of titanite indicate long-standing high- $\mathrm{T}$ conditions at the western margin of Gondwana (Argentina, 26-29 S): Journal of Metamorphic Geology, v. 21, p. 649-662.

Lucassen, F., Becchio, R., and Franz, G., 2010, The Early Palaeozoic high-grade metamorphism at the active continental margin of West Gondwana in the Andes (NW Argentina/N Chile): International Journal of Earth Sciences, v. 100, no. 2-3, p. $445-463$.

Ludwig, K.R., 2009. SQUID 2, a user's manual. Berkeley Geochronology Center Special Publication 2, pp.100.

Ludwig, K.R., 2012. Isoplot 3.75, a geochronological toolkit for Excel. Berkeley Geochronology Center Special Publication 5, pp.75.

Meira, V.T., Neto, M.D.C.C., González, P.D., Basei, M.Â.S., and Varela, R., 2012, Ordovician klippen structures of the Sierra de Umango: New insights on Tectonic evolution of the Western Sierras Pampeanas, Argentina: Journal of South American Earth Sciences, v. 37, p. 154-174, doi: 10.1016/j.jsames.2012.02.002.

Miller, H., and Söllner, F., 2005, The Famatina complex (NW Argentina): back-docking of an island arc or terrane accretion? Early Palaeozoic geodynamics at the western Gondwana margin: Geological Society, London, Special Publications, v. 246, no. 1, p. 241-256, doi: 10.1144/gsl.sp.2005.246.01.08.

Mulcahy, S.R., Roeske, S.M., McClelland, W.C., Ellis, J.R., Jourdan, F., Renne, P.R., Vervoort, J.D., and Vujovich, G.I., 2014, Multiple migmatite events and cooling from granulite facies metamorphism within the Famatina arc margin of northwest Argentina: Tectonics, v. 33, p. 1-25.

Mulcahy, S.R., Roeske, S.M., McClelland, W.C., Jourdan, F., Iriondo, A., Renne, P.R., Vervoort, J.D., and Vujovich, G.I., 2011, Structural evolution of a composite middle to lower crustal section: The Sierra de Pie de Palo, northwest Argentina: Tectonics, v. 30, p. TC1005.

Mulcahy, S.R., Roeske, S.M., McClelland, W.C., Nomade, S., and Renne, P.R., 2007, Cambrian initiation of the Las Pirquitas thrust of the western Sierras Pampeanas, Argentina: Implications for the tectonic evolution of the proto-Andean margin of South America: Geology, v. 35, p. 443-446. 
Porcher, C.C., Fernandes, L.A., Vujovich, G.I., and Chernicoff, C.J., 2004, Thermobarometry, Sm/Nd Ages and Geophysical Evidence for the Location of the Suture Zone Between Cuyania and the Western Proto-Andean Margin of Gondwana: Gondwana Research, v. 7, no. 4, p. 1057-1076.

Powell, R., and Holland, T.J.B., 2008, On thermobarometry: Journal of Metamorphic Geology, v. 26, p. 155-179.

Powell, R., and Holland, T., 1994, Optimal geothermometry and geobarometry: American Mineralogist, v. 79, p. 120-133.

Rapela, C.W., Pankhurst, R.J., Casquet, C., Baldo, E., Galindo, C., Fanning, C.M., and Dahlquist, J.M., 2010, The Western Sierras Pampeanas: Protracted Grenvilleage history (1330-1030 Ma) of intra-oceanic arcs, subduction-accretion at continental-edge and AMCG intraplate magmatism: Journal of South American Earth Sciences, v. 29, p. 105- 127.

Rapela, C.W., Verdecchia, S.O., Casquet, C., Pankhurst, R.J., Baldo, E.G., Galindo, C., Murra, J.A., Dahlquist, J.A., and Fanning, C.M., 2016, Identifying Laurentian and SW Gondwana sources in the Neoproterozoic to Early Paleozoic metasedimentary rocks of the Sierras Pampeanas: Paleogeographic and tectonic implications: Gondwana Research, v. 32, p. 193-212.

Scherer, E., Münker, C., and Mezger, K. (2001), Calibration of the lutetium-hafnium clock, Science, 293(5530), 683-687, doi:10.1126/science.1061372.

Söderlund, U., Patchett, P. J., Vervoort, J. D., and Isachsen, C. E. (2004), The $176 \mathrm{Lu}$ decay constant determined by $\mathrm{Lu}-\mathrm{Hf}$ and $\mathrm{U}-\mathrm{Pb}$ isotope systematics of Precambrian mafic intrusions, Earth and Planetary Science Letters, 219(3), 311-324.

Spear, F.S., and Cheney, J.T., 1989, A petrogenetic grid for pelitic schists in the system SiO2- Al2O3-FeO-MgO-K2O-H2O: Contributions to Mineralogy and Petrology, v. 101, p. 149-164, doi: 10.1007/BF00375302.

Spear, F.S., Kohn, M.J., Cheney, J.T., P-T paths from anatectic pelites. Contributions to Mineralogy and Petrology 1999; 134:17-32, doi: 10.1007/s004100050466.

Stacey, J. and Kramers, J.D. 1975, Approximation of terrestrial lead isotope evolution by a two-stage model: Earth and Planetary Science Letters, 26, p. 207-221.

Steenken, A., Luchi, M.G.L.D., Dopico, C.M., Drobe, M., Wemmer, K., and Siegesmund, S., 2010, The Neoproterozoic-early Paleozoic metamorphic and magmatic 
evolution of the Eastern Sierras Pampeanas: an overview: International Journal of Earth Sciences, v. 100, no. 2-3, p. 465-488, doi: 10.1007/s00531-010-0624-0.

Steenken, A., Wemmer, K., Martino, R.D., Luchi, M.G.L.D., Guereschi, A., and Siegesmund, S., 2010, Post-Pampean cooling and the uplift of the Sierras Pampeanas in the west of Córdoba (Central Argentina): Neues Jahrbuch für Geologie und Paläontologie - Abhandlungen, v. 256, no. 2, p. 235-255, doi: 10.1127/0077-7749/2010/0094.

Thompson, A.B., and England, P.C., 1984, Pressure-Temperature-Time Paths of Regional Metamorphism II. Their Inference and Interpretation using Mineral Assemblages in Metamorphic Rocks: Journal of Petrology, v. 25, p. 929-955.

Thompson, A.B., Schulmann, K., and Jezek, J., 1997, Thermal evolution and exhumation in obliquely convergent (transpressive) orogens. Tectonophysics, v. 280, no. 1-2, p. 171-184, doi: 10.1016/s0040-1951(97)00144-3.

Van Achterbergh E., Ryan C.G., Griffin W.L., 2000, Glitter: on-line interactive data reduction for the Laser Ablation ICP-MS Microprobe. Ninth Annual V.M. Goldschmidt Conference, 22-27 August 1999. Cambridge, Massachusetts. abstract 7215 .

Varela, R., Basei, M.A.S., González, P.D., Sato, A.M., Naipauer, M., Neto, M.C., Cingolani, C.A., Meria, V.T., Accretion of Grenvillian terranes to the southwestern border of the Río de la Plata craton, western Argentina. International Journal of Earth Sciences 2010; 100:243-72. doi: 10.1007/s00531-010-0614-2.

Whitmeyer, S.J., and Simpson, C., 2004, Regional deformation of the Sierra de San Luis, Argentina: Implications for the Paleozoic development of western Gondwana: Tectonics, v. 23, no. 1, doi: 10.1029/2003tc001542.

Willner, A.P., Gerdes, A., Massonne, H.-J., Schmidt, A., Sudo, M., Thomson, S.N., and Vujovich, G., 2010, The geodynamics of collision of a microplate (Chilenia) in Devonian times deduced by the pressure-temperature-time evolution within part of a collisional belt (Guarguaraz Complex, W-Argentina): Contributions to Mineralogy and Petrology, v. 162, no. 2, p. 303-327, doi: 10.1007/s00410-0100598-8. 
Table 1: Sample Locations

\begin{tabular}{lrrrrr}
\hline Sample & Latitude & Longitude & Sample & Latitude & Longitude \\
\hline AT-004 & -29.056 & -68.782 & AT-068 & -29.186 & -68.457 \\
AT-005 & -29.04 & -68.783 & AT-070 & -29.187 & -68.455 \\
AT-006 & -29.041 & -68.782 & AT-071 & -29.193 & -68.482 \\
AT-007 & -29.109 & -68.749 & AT-072 & -29.192 & -68.482 \\
AT-009 & -29.188 & -68.466 & AT-073 & -29.195 & -68.482 \\
AT-011 & -29.188 & -68.47 & AT-076 & -29.201 & -68.473 \\
AT-013 & -29.189 & -68.473 & AT-079 & -29.188 & -68.461 \\
AT-015 & -29.189 & -68.474 & AT-081 & -29.187 & -68.459 \\
AT-017 & -29.191 & -68.494 & AT-082 & -29.186 & -68.457 \\
AT-019 & -29.189 & -68.5 & AT-083 & -29.188 & -68.446 \\
AT-020 & -29.19 & -68.508 & AT-085 & -29.19 & -68.444 \\
AT-021 & -29.193 & -68.514 & AT-090 & -29.19 & -68.397 \\
AT-026 & -29.221 & -68.366 & AT-092 & -29.19 & -68.413 \\
AT-028 & -29.222 & -68.367 & AT-098 & -29.194 & -68.417 \\
AT-032 & -29.214 & -68.374 & AT-107 & -29.197 & -68.472 \\
AT-041 & -29.212 & -68.388 & AT-109 & -29.201 & -68.473 \\
AT-042 & -29.214 & -68.379 & AT-111 & -29.193 & -68.48 \\
AT-044 & -29.214 & -68.378 & AT-113 & -29.199 & -68.482 \\
AT-046 & -29.285 & -68.282 & AT-115 & -29.21 & -68.48 \\
AT-047 & -29.287 & -68.283 & AT-116 & -29.195 & -68.535 \\
AT-048 & -29.234 & -68.26 & AT-117 & -29.195 & -68.533 \\
AT-049 & -29.2 & -68.38 & AT-119 & -29.194 & -68.526 \\
AT-056 & -29.205 & -68.391 & AT-121 & -29.157 & -68.491 \\
AT-057 & -29.205 & -68.393 & AT-134 & -29.158 & -68.448 \\
AT-059 & -29.467 & -68.493 & AT-136 & -29.156 & -68.443 \\
AT-060 & -29.466 & -68.492 & AT-138 & -29.158 & -68.443 \\
AT-062 & -29.466 & -68.489 & AT-140 & -29.16 & -68.443 \\
AT-064 & -29.189 & -68.48 & AT-176 & -29.403 & -68.415 \\
AT-065 & -29.188 & -68.477 & AT-180 & -29.403 & -68.423 \\
AT-066 & -29.188 & -68.471 & AT-182 & -29.401 & -68.429 \\
\hline & & & & &
\end{tabular}


Table 2: Sample Mineralogy

\begin{tabular}{|c|c|c|c|c|c|c|c|c|c|c|c|c|c|c|c|c|c|c|c|c|c|}
\hline Sample & $\mathrm{Chl}$ & $\mathrm{Bt}$ & Grt & St & Ky & Sil & Crd & Ms & Kfs & $\mathrm{Plg}$ & Qtz & Cpx & Amp & Ttn & Tur & Ap & $\mathrm{Mnz}$ & $\mathrm{Rt}$ & $\| \mathrm{m}$ & Scp & Cal \\
\hline AT-004b & & $x$ & $x$ & & & & & $x$ & & $x$ & $X$ & & & & & & & & & & \\
\hline AT-004c & & $x$ & & & & & & & & $x$ & $x$ & & $x$ & & & & & & & & \\
\hline AT-005 & & $x$ & & & & & & & & $x$ & $x$ & & & & & & & & & & \\
\hline AT-009 & $x$ & $x$ & $x$ & & & & & $x$ & & & $x$ & & & & & & & & & & \\
\hline AT-011 & & $x$ & $x$ & & & & & & & $x$ & $x$ & & $x$ & $x$ & $x$ & & & & & & \\
\hline AT-013 & & $x$ & $x$ & & & & & $x$ & $x$ & $x$ & $x$ & & & $x$ & & & & & & & \\
\hline AT-015 & & $x$ & $x$ & & & & & & & $x$ & $x$ & & $x$ & & $x$ & & & $x$ & & & \\
\hline AT-017 & $x$ & $x$ & $x$ & & & & & $x$ & & $x$ & $x$ & & & & & & & & $x$ & & \\
\hline AT-019 & & $x$ & $x$ & & & & & $x$ & & $x$ & $x$ & & & & & & & $x$ & $x$ & & \\
\hline AT-020 & & $x$ & $x$ & & & & & $x$ & & $x$ & $x$ & & & & $x$ & & & $x$ & & & \\
\hline AT-021a & & $x$ & $x$ & & & & & $x$ & & $x$ & $x$ & & & & & & & & $x$ & & \\
\hline AT-021b & & $x$ & $x$ & & & & & $x$ & & $x$ & $x$ & & & & & & & $x$ & $x$ & & \\
\hline AT-021c & & $x$ & $x$ & & & & & $x$ & & $x$ & $x$ & & & & & & & $x$ & & & \\
\hline AT-026a & & $x$ & $x$ & & & & & $x$ & & $x$ & $x$ & & & & & & & & & & \\
\hline AT-026b & & $x$ & $x$ & & & & & $x$ & & $x$ & $x$ & & $x$ & & & & & & $x$ & & \\
\hline AT-028a & & $x$ & $x$ & & & $x$ & & & $x$ & $x$ & $x$ & & & $x$ & $x$ & & $x$ & & $x$ & & \\
\hline AT-030a & & $x$ & $x$ & & & & & & & $x$ & $x$ & & & $x$ & & & & & $x$ & & \\
\hline AT-030b & & $x$ & $x$ & & & & & & & $x$ & $x$ & & & $x$ & & & & & $x$ & & \\
\hline AT-032a & & $x$ & $x$ & & & & & & & $x$ & $x$ & & $x$ & & & & & & $x$ & & \\
\hline AT-032b & & $x$ & $x$ & & & & & & & $x$ & $x$ & & $x$ & $x$ & & & & & $x$ & $x$ & \\
\hline AT-032C & & & $x$ & & & & & & & & & & $x$ & & & & & & $x$ & $x$ & \\
\hline AT-041 & $x$ & $x$ & $x$ & & & & & & & $x$ & $x$ & & $x$ & & & & & & & & \\
\hline AT-042 & & $x$ & $x$ & & & & & & & $x$ & $x$ & & $x$ & & & & & & $x$ & & $x$ \\
\hline AT-044 & & $x$ & $x$ & & & & & & & $x$ & $x$ & & & $x$ & & & & & $x$ & & \\
\hline AR-046 & & $x$ & $x$ & & & & & & & $x$ & $x$ & & & & $x$ & & & & & & \\
\hline AT-047a & & $x$ & & & & & $x$ & & & $x$ & $x$ & & & & & & & & $x$ & & \\
\hline AT-048a & & $x$ & $x$ & & & & & & & & & & $x$ & & & & & & $x$ & & $x$ \\
\hline AT-048b & & $x$ & $x$ & & & $x$ & & & & $x$ & $x$ & $x$ & $x$ & & & & & & & & $x$ \\
\hline AT-049 & & $x$ & & & & $x$ & & & & & $x$ & & & & $x$ & & & & & & \\
\hline
\end{tabular}


Table 2 (cont.): Sample Mineralogy

\begin{tabular}{|c|c|c|c|c|c|c|c|c|c|c|c|c|c|c|c|c|c|c|c|c|c|}
\hline Sample & $\mathrm{Chl}$ & $\mathrm{Bt}$ & Grt & St & Ky & Sil & Crd & Ms & $\mathrm{Kfs}$ & Plg & Qtz & Cpx & Amp & Ttn & Tur & Ap & Mnz & $\mathrm{Rt}$ & $\| \mathrm{m}$ & Scp & Cal \\
\hline AT-056 & & $x$ & $x$ & & & & & $x$ & & $x$ & $X$ & & & & $x$ & & & & & & $x$ \\
\hline AT-057 & & $x$ & $X$ & & & & & & & $x$ & $x$ & & $X$ & & $X$ & & & & $x$ & & \\
\hline AT-058 & & $x$ & $X$ & & & & & & & $X$ & $X$ & & $X$ & $X$ & & & & & & & \\
\hline AT-059 & & $X$ & $X$ & & & & & & $X$ & $X$ & $X$ & & & & & & & & $X$ & & \\
\hline AT-060 & $X$ & $X$ & $X$ & $X$ & & & & $X$ & & $x$ & $x$ & & & $X$ & $X$ & & & & $x$ & & \\
\hline AT-062 & & & & & & & & $X$ & & $X$ & $X$ & & & & & & & & $X$ & & \\
\hline AT-064 & & $x$ & $x$ & & & & & & $x$ & $x$ & $x$ & & & & $X$ & & & & $x$ & & $x$ \\
\hline AT-065 & $X$ & $x$ & $x$ & & & & & & & $x$ & $X$ & & & $X$ & & & & & $x$ & & \\
\hline AT-066 & & $X$ & $x$ & $X$ & & & & $x$ & & $X$ & $x$ & & & & & & & & $x$ & & \\
\hline AT-070 & $X$ & $X$ & $X$ & $X$ & & & & $X$ & & $X$ & $X$ & & & & & & & & $X$ & & \\
\hline AT-071 & $X$ & & $x$ & & & & & $X$ & & $x$ & $X$ & & & & $x$ & & & & $x$ & & \\
\hline AT-072 & & & $X$ & & & & & $x$ & $X$ & $x$ & $x$ & & & & & & & & & & \\
\hline AT-073 & $X$ & $x$ & $x$ & & & & & $x$ & & $x$ & $x$ & & & $x$ & & & & $x$ & $X$ & & \\
\hline AT-076a & & $X$ & $x$ & $X$ & & & & $X$ & & $X$ & $X$ & & & & $X$ & & & & & & \\
\hline AT-079 & $X$ & $X$ & $X$ & $X$ & & & & $X$ & & $X$ & $X$ & & & & & & & & $X$ & & \\
\hline AT-081 & & $x$ & $X$ & & & & & $X$ & & $X$ & $X$ & & & & & & & & & & \\
\hline AT-082 & $X$ & $X$ & $X$ & & & & & & & $X$ & $X$ & & & & $X$ & & & & $X$ & & \\
\hline AT-083 & & $X$ & $X$ & & $X$ & & & $X$ & & $X$ & $x$ & & & $X$ & & & & & $x$ & & \\
\hline AT-085 & & $X$ & $X$ & & & & & & & $X$ & $x$ & & & & & & & & $X$ & & $X$ \\
\hline AT-090a & & $X$ & $X$ & & & & & & & $X$ & $X$ & & & & & & & & $X$ & & \\
\hline AT-090b & & $X$ & $x$ & & & & & & & $X$ & $X$ & & & $X$ & & & & & $x$ & & \\
\hline AT-092 & & $X$ & $X$ & & & & & & $x$ & $X$ & $X$ & & $X$ & & & & & $X$ & $x$ & & \\
\hline AT-098 & & $X$ & $X$ & & & & & & & $X$ & $X$ & & $X$ & & & & & & $X$ & & \\
\hline AT-107 & & $x$ & $X$ & & & & & & $x$ & $X$ & $X$ & & & $X$ & $X$ & $X$ & & & $X$ & & \\
\hline AT-109a & & $X$ & $X$ & & & & & $X$ & & $X$ & $X$ & & & & & & & & $X$ & & \\
\hline AT-109b & & $X$ & $X$ & & & & & $X$ & & $X$ & $X$ & & & & & & & & $x$ & & \\
\hline AT109c & $X$ & $X$ & $X$ & & & & & & & $X$ & $X$ & & & & & & & & & & \\
\hline AT109d & & $X$ & $X$ & & & & & $X$ & & $X$ & $X$ & & & & $X$ & $X$ & & & $X$ & & \\
\hline AT-109e & & $x$ & $x$ & & & & & $x$ & & $x$ & $x$ & & & & & & & & $x$ & & \\
\hline
\end{tabular}


Table 2 (cont.): Sample Mineralogy

\begin{tabular}{|c|c|c|c|c|c|c|c|c|c|c|c|c|c|c|c|c|c|c|c|c|c|}
\hline Sample & $\mathrm{Chl}$ & $\mathrm{Bt}$ & Grt & St & $\mathrm{Ky}$ & Sil & Crd & Ms & $\mathrm{Kfs}$ & Plg & Qtz & Cpx & Amp & Ttn & Tur & $A p$ & Mnz & $\mathrm{Rt}$ & $\mathrm{IIm}$ & Scp & $\mathrm{Cal}$ \\
\hline AT-111a & $X$ & $x$ & $X$ & $x$ & & & & $x$ & & $X$ & $x$ & & & & & & & & $x$ & & \\
\hline AT-111b & & $x$ & $x$ & & & & & $x$ & $x$ & $x$ & $x$ & & & $x$ & & & & $x$ & $x$ & & \\
\hline AT-111c & & $x$ & $x$ & & & & & & $x$ & $x$ & $x$ & & & $x$ & $x$ & & & & $x$ & & \\
\hline AT-113 & $x$ & $x$ & $x$ & $x$ & & & & $x$ & & $x$ & $x$ & & & & & & & & $x$ & & \\
\hline AT-115 & $x$ & $x$ & $x$ & & & & & $x$ & & $x$ & $x$ & & & & & & & & $x$ & & \\
\hline AT-116a & $x$ & & $x$ & & & & & $x$ & & $x$ & $x$ & & & & & & & $x$ & $x$ & & \\
\hline AT116b & $x$ & $x$ & $x$ & & & & & $x$ & & $x$ & $x$ & & & & & & & & $x$ & & \\
\hline AT-116c & $x$ & $x$ & $x$ & & $x$ & & & $x$ & & $x$ & $x$ & & & & & & & & & & \\
\hline AT-117 & & $x$ & $x$ & & & & & $x$ & & $x$ & $x$ & & & & & & & $x$ & $x$ & & \\
\hline AT-119 & & $x$ & $x$ & & & & & $x$ & & $x$ & $x$ & & & & & & & $x$ & $x$ & & \\
\hline AT-121a & & $x$ & $x$ & & & & & $x$ & & $x$ & $x$ & & & & & & & $x$ & $x$ & & \\
\hline AT-121b & & & $x$ & & & & & $x$ & & $x$ & $x$ & & & & $x$ & & & $x$ & $x$ & & \\
\hline AT-134 & & $x$ & $x$ & $x$ & $x$ & & & & & $x$ & $x$ & & & & & & & & $x$ & & \\
\hline AT-136a & & & $x$ & & $x$ & & & & & $x$ & $x$ & & & & & $x$ & & $x$ & $x$ & & \\
\hline AT-136b & & $x$ & $x$ & $x$ & $x$ & & & $x$ & & $x$ & $x$ & & & & & & & & $x$ & & \\
\hline AT-138 & & $x$ & $x$ & & $x$ & & & $x$ & & $x$ & $x$ & & & & & & & & $x$ & & \\
\hline AT-140 & & $x$ & $x$ & & $x$ & & & $x$ & & $x$ & $x$ & & & & & & & & $x$ & & \\
\hline AT-176 & & $x$ & $x$ & & & & & $x$ & & $x$ & $x$ & & & & $x$ & & & & $x$ & & \\
\hline AT-178 & & $x$ & $x$ & & & & & $x$ & & $x$ & $x$ & & & & $x$ & & & & $x$ & & \\
\hline AT-180 & & $x$ & $x$ & & & & & $x$ & & $x$ & $x$ & & & & & & & & $x$ & & \\
\hline AT-182 & & $x$ & $x$ & & & & & $x$ & & $x$ & $x$ & & & & & & & & $x$ & & \\
\hline
\end{tabular}


Table 3: Pressure - Temperature summary

\begin{tabular}{ccccccccccc}
\hline Sample & Latitude & Longitude & Assemblage & ${ }^{\circ} \mathrm{C}$ & $\pm 2 \mathrm{~s}$ & kbar & $\pm 2 \mathrm{~s}$ & cor & ofit & fit \\
\hline El Zaino Complex & & & & & & & & & & \\
AT-021a & -29.19322 & -68.51361 & Grt-Bt-Ms-Plg-Kfs & 564 & 91 & 8.2 & 1.4 & 0.861 & 0.82 & 1.61 \\
AT-021b & -29.19322 & -68.51361 & Grt-Bt-Amp-Plg & 489 & 71 & 7.3 & 1.6 & 0.559 & 1.45 & 1.54 \\
AT-017 & -29.19053 & -68.49359 & Grt-Bt-Ms-Plg-Chl & 575 & 14 & 8.2 & 0.7 & 0.333 & 0.73 & 1.54 \\
Maz Shear Zone & & & & & & & & & & \\
AT-073 & -29.19457 & -68.48200 & Grt-Bt-Ms-Plg & 602 & 90 & 8.3 & 1.4 & 0.800 & 0.86 & 1.61 \\
AT-015 & -29.18856 & -68.47404 & Grt-Bt-Plg-Amp & 673 & 142 & 8.6 & 1.7 & 0.795 & 1.24 & 1.73 \\
AT-076 & -29.20108 & -68.47318 & Grt-Bt-Ms-Plg-St & 653 & 27 & 7.7 & 1.1 & 0.742 & 0.30 & 1.61 \\
Maz Complex & & & & & & & & & & \\
AT-066 & -29.18795 & -68.47084 & Grt-St-Bt-Ms & 706 & 34 & 9.0 & 1.5 & 0.928 & 0.53 & 1.61 \\
AT-079 & -29.18817 & -68.46121 & Grt-St-Bt-Ms-Plg-Chl & 647 & 47 & 7.0 & 1.1 & 0.756 & 0.77 & 1.54 \\
AT-068 & -29.18615 & -68.45705 & Grt-St-Bt-Ms-Plg & 694 & 27 & 7.2 & 1.1 & 0.840 & 0.72 & 1.54 \\
AT-070 & -29.18690 & -68.45453 & Grt-St-Bt-Ms-Plg-Chl & 613 & 13 & 6.6 & 0.8 & 0.224 & 0.53 & 1.49 \\
AT-083 & -29.18825 & -68.44635 & Grt-St-Bt-Ms & 616 & 51 & 6.7 & 1.0 & -0.263 & 1.11 & 1.54 \\
AT-098 & -29.19443 & -68.41742 & Grt-Bt-Plg-Amp & 676 & 112 & 7.8 & 1.4 & 0.486 & 0.57 & 1.96 \\
AT-092 & -29.18971 & -68.41295 & Grt-Bt-Plg-Amp & 690 & 74 & 7.9 & 1.6 & 0.491 & 1.18 & 1.61 \\
AT-056 & -29.20469 & -68.39146 & Grt-Bt-Plg-Kfs-Ms & 804 & 167 & 10.6 & 1.1 & -0.016 & 0.97 & 1.96 \\
AT-041 & -29.21208 & -68.38789 & Grt-Plg-Amp-Bt-Kfs & 749 & 120 & 9.0 & 1.6 & 0.581 & 0.25 & 1.73 \\
AT-042 & -29.21378 & -68.37942 & Grt-Plg-Amp & 725 & 118 & 9.7 & 2.0 & 0.663 & 1.50 & 1.73 \\
AT-044 & -29.21397 & -68.37800 & Grt-Bt-Ms-Kfs & 723 & 142 & 10.0 & 3.1 & 0.507 & & \\
AT-028 & -29.22158 & -68.36735 & Grt-Bt-Plg-Kfs & 878 & 56 & 10.3 & 1.6 & 0.272 & 0.61 & 1.73 \\
Ramaditas Complex & & & & & & & & & & \\
AT-047 & -29.28666 & -68.28350 & Grt-Bt-Plg-Cd & 856 & 160 & 5.5 & 1.5 & 0.261 & 1.10 & 1.96 \\
\hline
\end{tabular}


Table 4: Lu - Hf Summary

\begin{tabular}{|c|c|c|c|c|c|c|}
\hline Sample & Mineral & Lu (ppm) & $\mathrm{Hf}(\mathrm{ppm})$ & ${ }^{176} \mathrm{Lu} /{ }^{177} \mathrm{Hf}$ & ${ }^{176} \mathrm{Hf} /{ }^{177} \mathrm{Hf}$ & $\pm 2 \sigma$ \\
\hline \multicolumn{7}{|l|}{ AT-021 } \\
\hline \multicolumn{7}{|c|}{$423 \pm 10 \mathrm{Ma} M S W D=4.6$} \\
\hline & Garnet & 7.63 & 2.66 & 0.4064 & 0.285705 & 15 \\
\hline & Garnet & 5.73 & 1.93 & 0.4224 & 0.285818 & 15 \\
\hline & Garnet & 4.71 & 2.63 & 0.2549 & 0.284460 & 15 \\
\hline & Garnet & 3.19 & 1.91 & 0.2362 & 0.284326 & 15 \\
\hline & Whole Rock & 0.495 & 8.82 & 0.0080 & 0.282538 & 15 \\
\hline & Whole Rock & 0.432 & 4.96 & 0.0123 & 0.282634 & 15 \\
\hline \multicolumn{7}{|l|}{ AT-076 } \\
\hline \multicolumn{7}{|c|}{$429 \pm 5$ Ma MSWD = 2.6} \\
\hline & Garnet & 6.73 & 0.560 & 0.3350 & 0.285201 & 15 \\
\hline & Garnet & 7.16 & 0.470 & 0.3566 & 0.285394 & 16 \\
\hline & Garnet & 6.35 & 0.470 & 0.3663 & 0.285452 & 15 \\
\hline & Garnet & 9.09 & 0.500 & 0.3806 & 0.285573 & 15 \\
\hline & Whole Rock & 3.51 & 0.530 & 0.0117 & 0.282588 & 15 \\
\hline & Whole Rock & 3.50 & 0.520 & 0.0162 & 0.282655 & 15 \\
\hline \multicolumn{7}{|l|}{ AT-015 } \\
\hline \multicolumn{7}{|c|}{$428 \pm 9$ Ma MSWD $=5.6$} \\
\hline & Garnet & 7.15 & 0.144 & 7.105 & 0.339633 & 21 \\
\hline & Garnet & 6.72 & 0.142 & 6.786 & 0.336439 & 20 \\
\hline & Garnet & 7.20 & 0.085 & 12.27 & 0.380860 & 26 \\
\hline & Garnet & 7.03 & 0.107 & 9.456 & 0.356599 & 23 \\
\hline & Whole Rock & 1.88 & 8.74 & 0.0305 & 0.282703 & 15 \\
\hline & Whole Rock & 1.97 & 1.75 & 0.1595 & 0.283902 & 15 \\
\hline \multicolumn{7}{|l|}{ AT-068 } \\
\hline \multicolumn{7}{|c|}{$591 \pm 59 \mathrm{Ma}, 759 \pm 54 \mathrm{Ma}$} \\
\hline & Garnet & 6.51 & 2.09 & 0.4421 & 0.287954 & 15 \\
\hline & Garnet & 6.84 & 2.24 & 0.4336 & 0.287606 & 15 \\
\hline & Garnet & 6.69 & 2.16 & 0.4396 & 0.286907 & 15 \\
\hline & Garnet & 6.58 & 1.80 & 0.5203 & 0.287443 & 15 \\
\hline & Whole Rock & 0.423 & 10.6 & 0.0057 & 0.281706 & 15 \\
\hline & Whole Rock & 0.236 & 3.47 & 0.0097 & 0.281799 & 15 \\
\hline \multicolumn{7}{|l|}{ AT-028 } \\
\hline \multicolumn{7}{|c|}{$1031 \pm 6.2 \mathrm{Ma}, 1074 \pm 6.4 \mathrm{Ma}$} \\
\hline & Garnet & 1.46 & 0.730 & 0.2828 & 0.28732 & 15 \\
\hline & Garnet & 1.81 & 0.850 & 0.3016 & 0.28753 & 15 \\
\hline & Garnet & 2.00 & 0.950 & 0.2998 & 0.28748 & 15 \\
\hline & Garnet & 1.81 & 0.880 & 0.2937 & 0.28761 & 15 \\
\hline & Whole Rock & 0.050 & 6.710 & 0.0012 & 0.28168 & 15 \\
\hline & Whole Rock & 0.040 & 1.120 & 0.0049 & 0.28173 & 15 \\
\hline \multicolumn{7}{|l|}{ AT-047 } \\
\hline \multicolumn{7}{|c|}{$449 \pm 1.6 \mathrm{Ma}, 461 \pm 1.7 \mathrm{Ma}$} \\
\hline & Garnet & 10.55 & 0.810 & 1.854 & 0.298613 & 16 \\
\hline & Garnet & 11.49 & 0.840 & 1.957 & 0.299025 & 16 \\
\hline & Garnet & 11.84 & 0.710 & 2.378 & 0.302597 & 16 \\
\hline & Garnet & 11.36 & 0.710 & 2.291 & 0.302277 & 16 \\
\hline & Whole Rock & 0.270 & 6.21 & 0.0063 & 0.282584 & 15 \\
\hline & Whole Rock & 0.180 & 1.04 & 0.0238 & 0.282992 & 15 \\
\hline
\end{tabular}


Table 5: U - Pb Summary

\begin{tabular}{|c|c|c|c|c|c|c|c|c|c|c|c|c|c|c|}
\hline \multicolumn{3}{|c|}{ Concentrations } & \multicolumn{6}{|c|}{ Atomic Ratios } & \multicolumn{6}{|c|}{ Age (Ma) } \\
\hline Spot & $\mathbf{U}$ & Th & Th/U & $206 \mathrm{~Pb}$ & $f 206$ & $238 \mathrm{U} / 206 \mathrm{~Pb}$ & $\%$ err & 207Pb/206Pb & $\%$ err & $206 \mathrm{~Pb} / 238 \mathrm{U}$ & $\%$ err & $206 \mathrm{~Pb} / 238 \mathrm{U}$ & err abs & Weighted Average age \\
\hline AT-068 & $\overline{(p p m)}$ & (ppm) & & (ppm) & $(\%)$ & & (1s) & & (1s) & & (1s) & & (1s) & $(2 \mathrm{~s})$ \\
\hline 68-36A.1 & 8568 & 9961 & 1.2 & 114 & 4.8 & 61.49 & 19.8 & 0.0577 & 114.3 & 0.0157 & 19.9 & 99 & 21 & $410.6 \pm 1.4 \mathrm{Ma}$ \\
\hline 68-05A.1 & 574.3 & 2607 & 4.5 & 15 & -0.3 & 32.23 & 45.4 & 0.0207 & 77.6 & 0.0300 & 45.4 & 198 & 89 & MSWD: 1.57 \\
\hline 68-14B.1 & 3815 & 59150 & 15.5 & 200 & 8.9 & 14.96 & 2.4 & 0.0709 & 47.0 & 0.0622 & 3.8 & 381 & 14 & \\
\hline 68-12C.1 & 2973 & 31970 & 10.8 & 158 & 1.1 & 16.01 & 1.1 & 0.0526 & 4.1 & 0.0617 & 1.2 & 387 & 4 & \\
\hline 68-08A.1 & 4435 & 36268 & 8.2 & 237 & 2.9 & 15.63 & 0.8 & 0.0650 & 5.2 & 0.0630 & 0.8 & 389 & 3 & \\
\hline 68-03C.1 & 2061 & 12485 & 6.1 & 110 & -0.2 & 16.11 & 3.3 & 0.0505 & 6.5 & 0.0619 & 3.3 & 389 & 13 & \\
\hline 68-04A.1 & 2411 & 24146 & 10.0 & 133 & 1.8 & 15.33 & 0.8 & 0.0540 & 5.0 & 0.0640 & 0.8 & 400 & 3 & \\
\hline 68-03В.1 & 3676 & 33052 & 9.0 & 203 & 0.6 & 15.49 & 1.0 & 0.0556 & 1.5 & 0.0643 & 1.0 & 401 & 4 & \\
\hline 68-14A.1 & 2728 & 33828 & 12.4 & 151 & 7.0 & 14.43 & 1.4 & 0.0529 & 15.5 & 0.0643 & 1.5 & 403 & 6 & \\
\hline 68-11A.1 & 2780 & 23694 & 8.5 & 154 & 0.4 & 15.44 & 1.2 & 0.0553 & 1.3 & 0.0646 & 1.2 & 403 & 5 & \\
\hline 68-12B.1 & 4261 & 58848 & 13.8 & 238 & 7.9 & 14.15 & 3.2 & 0.0702 & 46.9 & 0.0663 & 3.8 & 406 & 19 & \\
\hline 68-03A.1 & 3534 & 25614 & 7.2 & 198 & 0.9 & 15.22 & 1.2 & 0.0567 & 1.8 & 0.0653 & 1.2 & 407 & 5 & \\
\hline 68-17A.1 & 2553 & 24877 & 9.7 & 143 & 0.5 & 15.25 & 1.0 & 0.0555 & 1.5 & 0.0653 & 1.1 & 407 & 4 & \\
\hline 68-13A.1 & 3181 & 30587 & 9.6 & 179 & 0.4 & 15.17 & 0.9 & 0.0566 & 1.2 & 0.0658 & 0.9 & 410 & 4 & \\
\hline 68-16B.1 & 2904 & 25593 & 8.8 & 164 & 1.2 & 15.03 & 1.3 & 0.0556 & 2.3 & 0.0658 & 1.3 & 410 & 5 & \\
\hline 68-17B.1 & 2635 & 23572 & 8.9 & 149 & 3.0 & 14.76 & 0.8 & 0.0519 & 4.8 & 0.0655 & 0.8 & 410 & 3 & \\
\hline 68-12D.1 & 3271 & 27533 & 8.4 & 185 & 2.7 & 14.79 & 0.8 & 0.0571 & 3.3 & 0.0659 & 0.8 & 411 & 3 & \\
\hline 68-12A.1 & 2622 & 26280 & 10.0 & 149 & 0.3 & 15.07 & 1.3 & 0.0551 & 1.3 & 0.0661 & 1.3 & 413 & 5 & \\
\hline 68-13B.1 & 2955 & 25129 & 8.5 & 170 & 1.0 & 14.80 & 1.0 & 0.0569 & 1.9 & 0.0671 & 1.0 & 417 & 4 & \\
\hline 68-08C.1 & 2767 & 20944 & 7.6 & 159 & 0.3 & 14.86 & 1.3 & 0.0545 & 1.4 & 0.0670 & 1.3 & 418 & 5 & \\
\hline 68-08D.1 & 4073 & 26565 & 6.5 & 235 & 2.2 & 14.56 & 1.3 & 0.0539 & 3.5 & 0.0670 & 1.3 & 419 & 5 & \\
\hline 68-16A.1 & 2059 & 21512 & 10.4 & 119 & 0.4 & 14.81 & 1.0 & 0.0540 & 1.7 & 0.0672 & 1.0 & 420 & 4 & \\
\hline 68-18B.1 & 2752 & 28763 & 10.5 & 162 & 0.5 & 14.50 & 2.1 & 0.0561 & 1.9 & 0.0687 & 2.1 & 428 & 9 & \\
\hline 68-08B.1 & 2847 & 21496 & 7.6 & 170 & 0.3 & 14.38 & 0.9 & 0.0546 & 1.3 & 0.0693 & 0.9 & 432 & 4 & \\
\hline 68-18A.1 & 2405 & 15758 & 6.6 & 346 & 0.9 & 5.92 & 0.8 & 0.0781 & 0.6 & 0.1686 & 0.8 & 998 & 7 & \\
\hline
\end{tabular}


Table 5 (cont.): U - Pb Summary

\begin{tabular}{|c|c|c|c|c|c|c|c|c|c|c|c|c|c|c|}
\hline \multicolumn{3}{|c|}{ Concentrations } & \multicolumn{6}{|c|}{ Atomic Ratios } & \multicolumn{6}{|c|}{ Age (Ma) } \\
\hline Spot & $\mathbf{U}$ & Th & Th/U & $206 \mathrm{~Pb}$ & $f 206$ & $238 \mathrm{U} / 206 \mathrm{~Pb}$ & $\%$ err & $207 \mathrm{~Pb} / 206 \mathrm{~Pb}$ & $\%$ err & $206 \mathrm{~Pb} / 238 \mathrm{U}$ & $\%$ err & $206 \mathrm{~Pb} / 238 \mathrm{U}$ & err abs & Weighted Average age \\
\hline AT-047 & (ppm) & (ppm) & & (ppm) & $(\%)$ & & (1s) & & (1s) & & (1s) & & (1s) & $(2 \mathrm{~s})$ \\
\hline 47-14A.1 & 2328 & 18112 & 7.8 & 113 & 1.3 & 17.50 & 13.4 & 0.0552 & 11.0 & 0.0565 & 13.4 & 354 & 47 & $461.6 \pm 3.1 \mathrm{Ma}$ \\
\hline 47-08A.1 & 2595 & 23252 & 9.0 & 149 & 1.7 & 14.66 & 1.6 & 0.0547 & 7.6 & 0.0670 & 1.7 & 418 & 7 & MSWD: 1.6 \\
\hline 47-15A.1 & 1747 & 14417 & 8.3 & 102 & 0.2 & 14.64 & 1.5 & 0.0570 & 1.2 & 0.0683 & 1.5 & 425 & 6 & $426.1 \pm 7 \mathrm{Ma}$ \\
\hline 47-03A.1 & 2173 & 17327 & 8.0 & 128 & 0.5 & 14.50 & 1.7 & 0.0553 & 1.8 & 0.0686 & 1.7 & 428 & 7 & MSWD: 1.02 \\
\hline 47-09A.1 & 1497 & 11905 & 8.0 & 90 & 0.5 & 14.18 & 2.0 & 0.0577 & 1.6 & 0.0704 & 2.0 & 437 & 8 & \\
\hline 47-07A.1 & 2645 & 18281 & 6.9 & 161 & 0.1 & 14.14 & 1.5 & 0.0563 & 1.5 & 0.0707 & 1.5 & 440 & 6 & \\
\hline 47-17A.1 & 2193 & 15701 & 7.2 & 133 & 0.1 & 14.12 & 1.0 & 0.0559 & 1.1 & 0.0707 & 1.0 & 441 & 4 & \\
\hline 47-17C.1 & 2003 & 18108 & 9.0 & 122 & 0.2 & 14.03 & 1.9 & 0.0572 & 1.1 & 0.0713 & 1.9 & 443 & 8 & \\
\hline 47-02A.1 & 2048 & 16763 & 8.2 & 126 & 0.1 & 13.97 & 1.0 & 0.0556 & 1.2 & 0.0715 & 1.0 & 445 & 4 & \\
\hline 47-17B.1 & 1867 & 9908 & 5.3 & 118 & 0.2 & 13.63 & 1.1 & 0.0569 & 1.1 & 0.0733 & 1.1 & 456 & 5 & \\
\hline 47-04A.1 & 2230 & 15869 & 7.1 & 141 & 0.0 & 13.62 & 1.4 & 0.0557 & 0.9 & 0.0734 & 1.4 & 457 & 6 & \\
\hline 47-15B.1 & 1663 & 9658 & 5.8 & 105 & 0.1 & 13.56 & 0.8 & 0.0563 & 1.2 & 0.0737 & 0.8 & 458 & 4 & \\
\hline 47-05B.1 & 1890 & 15570 & 8.2 & 120 & 0.1 & 13.51 & 0.8 & 0.0563 & 1.1 & 0.0739 & 0.8 & 460 & 4 & \\
\hline 47-05C.1 & 1862 & 12864 & 6.9 & 119 & 0.0 & 13.48 & 0.9 & 0.0555 & 1.1 & 0.0741 & 0.9 & 461 & 4 & \\
\hline 47-08B.1 & 1904 & 16310 & 8.6 & 123 & -0.1 & 13.35 & 0.8 & 0.0550 & 1.2 & 0.0748 & 0.8 & 466 & 4 & \\
\hline 47-05A.1 & 1601 & 15183 & 9.5 & 105 & 0.0 & 13.15 & 1.0 & 0.0552 & 1.3 & 0.0759 & 1.0 & 472 & 5 & \\
\hline \multicolumn{3}{|c|}{ Concentrations } & \multicolumn{6}{|c|}{ Atomic Ratios } & \multicolumn{6}{|c|}{ Age (Ma) } \\
\hline Spot & $\mathbf{U}$ & Th & Th/U & $206 \mathrm{~Pb}$ & $f 206$ & $238 \mathrm{U} / 206 \mathrm{~Pb}$ & $\%$ err & $207 \mathrm{~Pb} / 206 \mathrm{~Pb}$ & $\%$ err & $206 \mathrm{~Pb} / 238 \mathrm{U}$ & $\%$ err & $206 \mathrm{~Pb} / 238 \mathrm{U}$ & err abs & Weighted Average age \\
\hline AT-076 & (ppm) & (ppm) & & (ppm) & $(\%)$ & & (1s) & & (1s) & & (1s) & & (1s) & $(2 \mathrm{~s})$ \\
\hline 76-05A.1 & 3147 & 13798 & 4.4 & 174 & 0.3 & 15.49 & 2.0 & 0.0563 & 1.9 & 0.0645 & 2.0 & 402 & 8 & $418.7 \pm 3.3 \mathrm{Ma}$ \\
\hline 76-06A.1 & 4317 & 30842 & 7.1 & 240 & 0.1 & 15.43 & 3.9 & 0.0547 & 1.0 & 0.0648 & 3.9 & 405 & 16 & MSWD: 1.14 \\
\hline 76-06B.1 & 3415 & 12904 & 3.8 & 190 & 0.2 & 15.37 & 4.4 & 0.0560 & 1.0 & 0.0650 & 4.4 & 405 & 17 & \\
\hline 76-07A.1 & 3583 & 11590 & 3.2 & 202 & 0.1 & 15.24 & 1.9 & 0.0558 & 0.8 & 0.0656 & 1.9 & 409 & 8 & \\
\hline 76-03B.1 & 3212 & 12469 & 3.9 & 182 & 0.2 & 15.12 & 1.4 & 0.0558 & 0.9 & 0.0660 & 1.4 & 412 & 6 & \\
\hline 76-03C.1 & 2838 & 14470 & 5.1 & 162 & 0.2 & 15.04 & 1.2 & 0.0564 & 0.9 & 0.0664 & 1.2 & 414 & 5 & \\
\hline 76-04a.1 & 3055 & 11045 & 3.6 & 177 & 0.2 & 14.82 & 1.1 & 0.0563 & 0.9 & 0.0674 & 1.1 & 420 & 5 & \\
\hline 76-02A.1 & 2491 & 9839 & 4.0 & 144 & 0.1 & 14.83 & 1.6 & 0.0564 & 0.9 & 0.0675 & 1.6 & 420 & 7 & \\
\hline 76-03A.1 & 2736 & 13320 & 4.9 & 159 & 0.1 & 14.78 & 1.3 & 0.0549 & 1.1 & 0.0676 & 1.3 & 422 & 5 & \\
\hline 76-08A.1 & 4143 & 22688 & 5.5 & 241 & 0.2 & 14.73 & 1.4 & 0.0556 & 0.9 & 0.0678 & 1.4 & 423 & 6 & \\
\hline 76-10A.1 & 3672 & 17579 & 4.8 & 214 & 0.2 & 14.72 & 2.2 & 0.0563 & 1.5 & 0.0679 & 2.2 & 423 & 9 & \\
\hline 76-09A.1 & 2462 & 10491 & 4.3 & 144 & 0.3 & 14.67 & 1.3 & 0.0568 & 0.9 & 0.0681 & 1.3 & 424 & 5 & \\
\hline 76-08B.1 & 4359 & 24239 & 5.6 & 255 & 0.0 & 14.67 & 1.2 & 0.0551 & 0.8 & 0.0681 & 1.2 & 425 & 5 & \\
\hline 76-08A.2 & 2872 & 24016 & 8.4 & 169 & 0.1 & 14.56 & 1.8 & 0.0543 & 1.2 & 0.0685 & 1.8 & 428 & 8 & \\
\hline
\end{tabular}


Table 5 (cont.): U - Pb Summary

\begin{tabular}{|c|c|c|c|c|c|c|c|c|c|c|c|c|c|c|}
\hline \multicolumn{3}{|c|}{ Concentrations } & \multicolumn{6}{|c|}{ Atomic Ratios } & \multicolumn{6}{|c|}{ Age (Ma) } \\
\hline Spot & $u$ & Th & Th/U & $206 \mathrm{~Pb}$ & $f 206$ & $238 \mathrm{U} / 206 \mathrm{~Pb}$ & $\%$ err & $207 \mathrm{~Pb} / 206 \mathrm{~Pb}$ & $\%$ err & $206 \mathrm{~Pb} / 238 \mathrm{U}$ & $\%$ err & $206 \mathrm{~Pb} / 238 \mathrm{U}$ & err abs & Weighted Average age \\
\hline AT-028 & $(\mathrm{ppm})$ & $(\mathrm{ppm})$ & & $(\mathrm{ppm})$ & $(\%)$ & & $(1 \mathrm{~s})$ & & (1s) & & (1s) & & $(1 \mathrm{~s})$ & $(2 \mathrm{~s})$ \\
\hline 28-09A.2 & 2121 & 23486 & 11.1 & 116 & 0.3 & 15.70 & 1.3 & 0.0549 & 1.5 & 0.0635 & 1.3 & 397 & 5 & $413.2 \pm 5 \mathrm{Ma}$ \\
\hline 28-14A.2 & 2063 & 32781 & 15.9 & 113 & 0.3 & 15.59 & 1.8 & 0.0559 & 1.4 & 0.0640 & 1.8 & 399 & 7 & MSWD: 7.68 \\
\hline 28-04A.1 & 1316 & 17576 & 13.4 & 75 & 2.0 & 14.87 & 1.6 & 0.0565 & 4.4 & 0.0660 & 1.6 & 411 & 7 & $1227.1 \pm 6.8 \mathrm{Ma}$ \\
\hline 28-03B. 2 & 940 & 32067 & 34.1 & 55 & 0.5 & 14.67 & 1.5 & 0.0573 & 4.3 & 0.0680 & 1.5 & 423 & 6 & MSWD: 1.55 \\
\hline 28-09a.1 & 1815 & 20322 & 11.2 & 108 & 0.5 & 14.39 & 1.2 & 0.0554 & 2.3 & 0.0692 & 1.2 & 431 & 5 & \\
\hline 28-06A.2 & 905 & 17435 & 19.3 & 84 & 1.3 & 9.18 & 6.3 & 0.0711 & 2.9 & 0.1088 & 6.3 & 658 & 41 & \\
\hline 28-14A.1 & 560 & 39184 & 69.9 & 57 & 1.0 & 8.39 & 1.8 & 0.0699 & 2.6 & 0.1190 & 1.8 & 719 & 13 & \\
\hline 28-07A.2 & 1225 & 23442 & 19.1 & 130 & 1.1 & 8.02 & 4.2 & 0.0720 & 1.7 & 0.1245 & 4.2 & 750 & 31 & \\
\hline 28-11A.1 & 538 & 31063 & 57.7 & 64 & 1.2 & 7.18 & 4.0 & 0.0734 & 3.2 & 0.1388 & 4.0 & 832 & 32 & \\
\hline 28-03A.1 & 606 & 22367 & 36.9 & 76 & 1.0 & 6.74 & 1.4 & 0.0753 & 1.4 & 0.1481 & 1.4 & 884 & 12 & \\
\hline 28-07B.1 & 604 & 16719 & 27.7 & 81 & 1.0 & 6.35 & 3.0 & 0.0759 & 1.1 & 0.1569 & 3.0 & 934 & 27 & \\
\hline 28-08B.1 & 2465 & 22110 & 9.0 & 377 & 1.0 & 5.56 & 1.3 & 0.0808 & 0.8 & 0.1795 & 1.3 & 1057 & 13 & \\
\hline 28-03B.1 & 696 & 31217 & 44.8 & 110 & 0.7 & 5.37 & 1.7 & 0.0811 & 1.1 & 0.1859 & 1.7 & 1093 & 18 & \\
\hline 28-06B.1 & 983 & 18955 & 19.3 & 157 & 0.6 & 5.35 & 2.4 & 0.0802 & 0.7 & 0.1867 & 2.4 & 1098 & 26 & \\
\hline 28-05A.1 & 743 & 24220 & 32.6 & 120 & 0.9 & 5.27 & 1.2 & 0.0806 & 1.2 & 0.1887 & 1.2 & 1110 & 12 & \\
\hline 28-10A.1 & 560 & 21900 & 39.1 & 94 & 0.1 & 5.10 & 1.2 & 0.0786 & 0.9 & 0.1958 & 1.2 & 1153 & 13 & \\
\hline 28-02a.1 & 888 & 23287 & 26.2 & 150 & 0.4 & 5.07 & 1.3 & 0.0818 & 0.7 & 0.1974 & 1.3 & 1157 & 15 & \\
\hline 28-03C.1 & 692 & 20810 & 30.1 & 119 & 0.4 & 4.99 & 1.4 & 0.0813 & 0.9 & 0.2002 & 1.4 & 1174 & 15 & \\
\hline 28-06A.1 & 750 & 19435 & 25.9 & 130 & 0.3 & 4.93 & 1.2 & 0.0814 & 0.8 & 0.2027 & 1.2 & 1187 & 14 & \\
\hline 28-13A.1 & 1488 & 20797 & 14.0 & 259 & 0.3 & 4.92 & 1.4 & 0.0815 & 0.6 & 0.2029 & 1.4 & 1188 & 16 & \\
\hline 28-08A.1 & 1097 & 16868 & 15.4 & 191 & 0.4 & 4.90 & 1.6 & 0.0827 & 1.3 & 0.2039 & 1.6 & 1193 & 19 & \\
\hline 28-10A.2 & 1072 & 33311 & 31.1 & 187 & 0.0 & 4.91 & 1.2 & 0.0798 & 0.7 & 0.2035 & 1.2 & 1194 & 13 & \\
\hline 28-10B.1 & 2855 & 24926 & 8.7 & 506 & 0.2 & 4.84 & 1.2 & 0.0818 & 0.4 & 0.2066 & 1.2 & 1209 & 14 & \\
\hline 28-10C.1 & 1584 & 24342 & 15.4 & 285 & 0.1 & 4.77 & 1.1 & 0.0812 & 0.5 & 0.2093 & 1.1 & 1225 & 13 & \\
\hline 28-07a-1.] & 3436 & 19535 & 5.7 & 629 & 0.0 & 4.69 & 1.5 & 0.0811 & 0.4 & 0.2129 & 1.5 & 1246 & 18 & \\
\hline
\end{tabular}


Table 6: Lu - Hf and U - Pb Summary

\begin{tabular}{|c|c|c|c|c|c|c|c|}
\hline Sample & Unit & Latitude & Longitude & Age (Ma) & \pm & MSWD & Comments \\
\hline & & & & Lu-HfGrt & & & \\
\hline AT-021 & Zaino Complex & -29.19322 & -68.51361 & 423 & 10 & 4.6 & \\
\hline AT-015 & Maz Shear Zone & -29.18856 & -68.47404 & 428 & 9 & 5.6 & \\
\hline AT-076 & Maz Shear Zone & -29.20108 & -68.47318 & 429 & 5 & 2.6 & \\
\hline AT-068 & Maz Complex & -29.18615 & -68.45705 & 759 & 54 & - & oldest grt \\
\hline AT-068 & & & & 591 & 59 & - & youngest grt \\
\hline AT-028 & Maz Complex & -29.22158 & -68.36735 & 1074 & 6.4 & - & oldest grt \\
\hline AT-028 & & & & 1031 & 6.2 & & youngest grt \\
\hline AT-047 & Ramaditas & -29.28666 & -68.28350 & 461 & 1.7 & - & oldest grt \\
\hline \multirow[t]{2}{*}{ AT-047 } & & & & 449 & 1.6 & - & youngest grt \\
\hline & & & & $U-P b M n z$ & & & \\
\hline AT-076 & Maz Shear Zone & -29.20108 & -68.47318 & 418.7 & 3.3 & 1.14 & weighted mean \\
\hline AT-068 & Maz Complex & -29.18615 & -68.45705 & 410.6 & 2.4 & 1.57 & weighted mean \\
\hline AT-068 & & & & 1214 & 12 & 2.2 & upper intercept \\
\hline AT-028 & Maz Complex & -29.22158 & -68.36735 & 413.2 & 5 & 7.68 & weighted mean \\
\hline AT-028 & & & & 1227.1 & 6.8 & 1.55 & weighted mean \\
\hline AT-047 & Ramaditas & -29.28666 & -68.28350 & 426.1 & 7 & 1.02 & weighted mean \\
\hline AT-047 & & & & 461.6 & 3.1 & 1.6 & weighted mean \\
\hline
\end{tabular}


